University of Chicago Law School

Chicago Unbound

\title{
Reflecting on the Subject: A Critique of the Social Influence Conception of Deterrence, the Broken Windows Theory, and Order- Maintenance Policing New York Style
}

Bernard E. Harcourt

Follow this and additional works at: https://chicagounbound.uchicago.edu/journal_articles

Part of the Law Commons

\section{Recommended Citation}

Bernard E. Harcourt, "Reflecting on the Subject: A Critique of the Social Influence Conception of Deterrence, the Broken Windows Theory, and Order-Maintenance Policing New York Style," 97 Michigan Law Review 291 (1998).

This Article is brought to you for free and open access by the Faculty Scholarship at Chicago Unbound. It has been accepted for inclusion in Journal Articles by an authorized administrator of Chicago Unbound. For more information, please contact unbound@law.uchicago.edu. 


\section{REFLECTING ON THE SUBJECT: A CRITIQUE OF THE SOCIAL INFLUENCE CONCEPTION OF DETERRENCE, THE BROKEN WINDOWS THEORY, AND ORDER-MAINTENANCE POLICING NEW YORK STYLE}

Bernard E. Harcourt*

\section{TABLE of Contents}

INTRODUCTION ................................ 292

I. Order-Maintenance Policing: A Critical

Description................................ 301

A. Background ........................... 301

B. The Broken Windows Essay .............. 302

C. The Social Influence Conception of

Deterrence .............................. 305

II. The Lack of Social Science Evidence........ 308

A. Replicating Skogan's Study................ 309

B. The Sampson and Cohen Study ............. 329

C. New York City's Falling Crime Rates.......... 331

D. An Alternative Mechanism of Order-

Maintenance Policing: Enhanced Surveillance.. $\quad 339$

III. The Categories Underlying Order-

Maintenance Policing ...................... 343

A. Who Are the Disorderly? ................ 343

B. Tracing the Problem Back to Social Theory.... 347

C. Emile Durkheim on Legitimation and Legal

Regulation ..............................

* Associate Professor of Law, University of Arizona College of Law. A.B. 1984, Princeton; J.D. 1989, M.A. (Political Science) 1998, Ph.D. Candidate (Political Science), Harvard. - Ed. Special thanks for comments on earlier drafts to Seyla Benhabib, Thomas Ertman, Michael Gottfredson, David Golove, Travis Hirschi, Bonnie Honig, David Kennedy, Duncan Kennedy, Randall Kennedy, Toni Massaro, Tracey Meares, Frank Michelman, Martha Minow, Tanina Rostain, Carol Steiker, Richard Tuck, Robert Williams; participants at the 1998 annual meetings of the American Political Science Association and the Law and Society Association; and my colleagues in the work-in-progress workshop at the University of Arizona. Special thanks for comments and assistance on the quantitative analysis to Gary King, Michael Tomz, and the Data Center staff at Harvard University; and for exceptional research assistance to Maureen Garmon, Jenna Karadbil and Dev Stahlkopf. 
D. The Problem of Subject Creation ............. 352

IV. Michel Foucault and Subject Creation...... 354

A. Foucault on the Categories ................... 356

B. Foucault on Law....................... 365

C. The Implications for the Social Influence

Conception of Deterrence .................. 368

D. Subject Creation in Contemporary Criminal

Law Scholarship ....................... $\quad 371$

V. Revisiting Order-Maintenance Policing ..... 377

A. Complaints of Police Brutality and the NYPD . 377

B. Other Factors That Are Overshadowed by the Orderliness of Order-Maintenance Policing..... 381

C. Alternatives to Arrest........................ 384

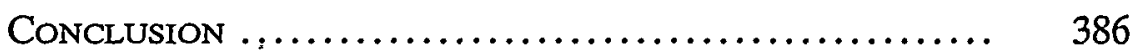

\section{INTRODUCTION}

In 1993, New York City began implementing the quality-of-life initiative, an order-maintenance policing strategy targeting minor misdemeanor offenses like turnstile jumping, aggressive panhandling, and public drinking. The policing initiative is premised on the broken windows theory of deterrence, namely the hypothesis that minor physical and social disorder, if left unattended in a neighborhood, causes serious crime. New York City's new policing strategy has met with overwhelming support in the press and among public officials, policymakers, sociologists, criminologists and political scientists. The media describe the "famous"1 Broken Windows essay $^{2}$ as "the bible of policing" and "the blueprint for community policing." 3 Order-maintenance policing has been called the "Holy Grail of the '90s."4 "There is little dispute that the theory works," says the ABA Journal.5 It has sparked "a revolution in American policing," according to the Christian Science Monitor, in an article captioned "One Man's Theory Is Cutting Crime in Urban Streets."6

1. See Robert Jones, The Puzzle Waiting for the New Chief, L.A. Times, Aug. 10, 1997, at B1 ("[T]he now-famous magazine article 'Broken Windows'"); John J. DiIulio, Jr., 'Windows' Puts New Light on Crime-fighting Efforts, Ideas, WASH. TimEs, Nov. 10, 1996, at B8.

2. James Q. Wilson \& George L. Kelling, Broken Windows, The Atzantrc Monthly, Mar. 1982, at 29.

3. Kevin Cullen, The Comish, Boston Globe MAG., May 25, 1997, at 12.

4. Jones, supra note 1.

5. Patricia G. Barnes, Safer Streets at What Cost?: Critics say the homeless and substance abusers are most likely to suffer when police crack down on petty offenses, A.B.A. J., June 1998 , at 24.

6. Christina Nifong, One Man's Theory Is Cutting Crime in Urban Streets, CHRISTIAN ScI. Monitor, Feb. 18, 1997, at 1. 
Even the recent U.S. News \& World Report cover story on crime a cover story that debunks nearly every hypothesis for the national decline in crime - makes a passing curtsy to the quality-of-life initiative: "Clearly, smarter policing was spectacularly decisive in some cities like New York."7 Former Police Commissioner William Bratton, the principal architect of the quality-of-life initiative, credits the broken windows theory with falling crime rates in New York City. "These successes didn't just happen," Bratton contends. "They were achieved by embracing the concept of community policing." versity, has conducted an empirical study of the broken windows theory and concludes that "'[b]roken windows' do need to be repaired quickly." George Kelling, co-author of Broken Windows and of a recent book entitled Fixing Broken Windows, contends that Skogan "established the causal links between disorder and serious crime - empirically verifying the 'Broken Windows' hypotheses."10 In this euphoria of support, it is today practically impossible to find a single scholarly article that takes issue with the quality-oflife initiative.11 It stands, in essence, uncontested - even in the legal academy.

7. Gordon Witkin, The Crime Bust, U.S. News \& WorID Rep., May 25, 1998, at 33. The one hypothesis that the cover story does not debunk is the crack hypothesis, namely the theory that the decline in crime is due to decreased crack consumption.

8. William J. Bratton, Editorial, New York's Police Should Not Retreat, N.Y. TIMEs, Aug. 19, 1997, at A27.

9. Wesley G. Skogan, Disorder and Decline: Crime and the Spiral of Decay in american Neighborhoods 75 (1990) [hereinafter Skogan, Disorder and Decline].

10. George Kelling \& Catherine M. Coles, Fixing Broken Windows: Restoring Order and Reducing Crime in Our Communities 24 (1996).

11. I have in fact found no published scholarship, with the exception of forthcoming, though as-of-yet unpublished, papers delivered at a recent conference convened by the Journal of Criminal Law and Criminology on the topic, Why is Crime Decreasing? See Jeffrey Fagan et al,, Declining Homicide in New York City: A Tale of Two Trends, 88 J. CRIM. L. \& CRIMINology (No. 4, forthcoming 1998) (discussed infra, text accompanying notes 170-173 and 189-197); Richard Curtis, The Improbable Transformation of Inner City Neighborhoods: Crime, Violence, Drugs and Use in the 1990's, $88 \mathrm{~J}$. CRIM. L. \& CRIMINology (No. 4, forthcoming 1998); Fox Butterfield, Reason for Dramatic Drop In Crime Puzzles the Experts, N.Y. TIMEs, Mar. 29, 1998, § 1, at 14 ("Professor Curtis gives Mayor Giuliani's police little credit for this transformation, viewing their repeated sweeps through Brunswick and arrests of its residents as largely angering the young people."). A very recent student note in the Yale Law Journal also criticizes the broken windows theory. See Gary Stewart, Note, Black Codes and Broken Windows: The Legacy of Racial Hegemony in Anti-Gang Civil Injunctions, 107 YALE L.J. 2249 (1998). To date, the principal published writings critical of the quality-of-life initiative consist of a handful of New York Times articles. See Michael Cooper, You're Under Arrest, N.Y. Times, Dec. 1, 1996, \& 13, at A1; Robert Lipsyte, From Sidewalk Skirmish to Main Event, N.Y. Tmes, Nov. 16, 1997, § 14, at A1; Matthew Purdy, In New York, the Handcuffs Are One-Size-Fits-All, N.Y. Times, Aug. 24, 1997, at A1; Deborah Sontag \& Dan Barry, Challenge to Authority: Disrespect as Catalyst for Brutality, N.Y. TIMEs, Nov. 19, 1997, at A1; see also Michael Massing, The Blue Revolution, The New York Review of Books, Nov. 19, 1998, at 32 (criticizing the broken windows theory and the quality-of-life initiative in relation 
Dan Kahan, a leading social norm proponent in the area of criminal law, forcefully advocates order-maintenance policing and, in particular, New York City's quality-of-life initiative. ${ }^{12}$ Kahan reports that order-maintenance policing "has been used with startlingly successful results in New York City." 13 He contends that the social influence conception of deterrence "makes it plausible to believe that order maintenance has in fact reduced crime in New York."14 Kahan also suggests that "[t]he work of criminologist Wesley Skogan supplies empirical support for the 'broken windows' hypothesis."15 Other social norm proponents rely heavily on the broken windows theory and essentially endorse order-maintenance policing. ${ }^{16}$

In fact, order-maintenance policing is one of the leading recommendations along what Kahan calls "the new path of deterrence."17 The new path is a loosely grouped set of initiatives in the area of crime and punishment, ranging from order-maintenance policing to curfews, gang-loitering laws, informal public-space zoning, reverse stings, and shaming penalties. ${ }^{18}$ The new path seeks to revitalize

to the drug problem). Even the civil libertarians are hedging their position on the quality-oflife initiative. Norman Seigel, executive director of the New York Civil Liberties Union, very cautiously remarks that "[t]here is a dark side to this quality-of-life issue. In some New Yorkers' minds, this city is becoming increasingly authoritarian." Norimitsu Onishi, Giuliani Crows as Theft Suspect Is Caught as a Jaywalker, N.Y. Times, Feb. 21, 1998, at B1 (quoting Seigel).

12. See Dan M. Kahan, Between Economics and Sociology: The New Path of Deterrence, 95 Mrch. L. Rev. 2477, 2488 (1997) [hereinafter Kahan, New Path]; Dan M. Kahan, Social Influence, Social Meaning, and Deterrence, 83 VA. L. REv. 349, $367-73$ (1997) [hereinafter Kahan, Social Influence].

13. Kahan, New Path, supra note 12, at 2488.

14. Kahan, Social Influence, supra note 12, at 372.

15. Id. at 369; see also Kahan, New Path, supra note 12, at 2488 n.62.

16. See Robert C. Ellickson, Controlling Chronic Misconduct in City Spaces: Of Panhandlers, Skid Rows, and Public-Space Zoning, 105 YALE L.J. 1165, 1171-73, 1177-79, 1182 (1996) (discussing the broken windows theory and advocating informal public-space zoning administered by trustworthy police officers with significant discretion); Debra Livingston, Police Discretion and the Quality of Life in Public Places: Courts, Communities, and the New Policing, 97 Colum. L. REv. 551, 581-91 (1997) (discussing the broken windows theory and advocating measures to manage police discretion in the context of the quality-of-life initiative); cf. Lawrence Lessig, The Regulation of Social Meaning, 62 U. CHI. L. REv. 943, 1039-40 (1995) (discussing one aspect of the quality-of-life initiative to illustrate a change in social meaning; however, he does not indicate one way or the other whether he supports that specific regulation of social meaning).

17. Kahan, New Path, supra note 12, at 2479.

18. See Ellickson, supra note 16 (advocating informal public-space zoning administered by trustworthy police officers with significant discretion); Kahan, New Path, supra note 12 (advocating curfews, gang-loitering laws, order-maintenance policing, reverse stings, and shaming penalties); Kahan, Social Influence, supra note 12 (arguing for order-maintenance policing, gang-loitering laws, and alternative sanctions); Dan M. Kahan, What Do Alternative Sanctions Mean, 63 U. CHI. L. Rev. 591 (1996) (advocating alternative sanctions like shaming penalties); Dan M. Kahan \& Tracey L. Meares, Foreword: The Coming Crisis of Criminal 
the argument for deterrence by infusing it with cutting-edge social science. Social norm proponents locate the new path of deterrence between economics and sociology. ${ }^{19}$ The new path represents, according to Kahan, "a third way, one that combines the virtues of both economics and sociology without succumbing to the vices of either." 20 From economics, the new path appropriates the idea that individuals are rational actors maximizing their utility. From sociology, the new path appropriates the idea that individuals are influenced, and their conduct is shaped, by social phenomena. The new path of deterrence is presented as an application of social norm theory to criminal law. ${ }^{21}$

In this Article, I critically examine the empirical evidence and the social influence explanation supporting New York City's experiment with order-maintenance policing. At the empirical level, I replicate the principal social scientific study that has attempted to establish the disorder-crime nexus, namely Wesley Skogan's Disorder and Decline: Crime and the Spiral of Decay in American Neighborhoods. ${ }^{22}$ I conclude that Skogan's data do not support the claim that reducing disorder deters more serious crime. As a preliminary matter, the data are missing a large number of values (thirty to forty percent, on average, of the relevant dependent and independent variables) for such a small sample of neighborhoods (at most, forty neighborhood observations). But even setting aside that problem, my replication of Skogan's study establishes that (a) certain types of crime like rape, purse snatching, and pocket-picking are not significantly related to disorder; (b) other types of crime like physical assault and burglary are not significantly related to disorder when neighborhood poverty, stability, and race are held constant; and (c) although 'robbery remains significantly related to

Procedure, 86 GEO. L.J. 1153, 1160-66 (1998) (advocating "the new community policing," including anti-loitering laws and curfews); Tracey L. Meares, It's a Question of Connections, 31 VAL. U. L. REv. 579 (1997) (advocating strengthening interdependent social networks and collective supervision of the community).

19. See Kahan, New Path, supra note 12, at 2477; see also Lessig, supra note 16, at 951 (social meaning "marries two traditions in social thought, one that we might call interpretive (anthropology, sociology) and the other, traditionally, noninterpretive (economics)"); $c f$. Kenneth Dau-Schmidt, Economics and Sociology: The Prospects for an Interdisciplinary Discourse on Law, 1997 WIs. L. Rev. 389 (1997).

20. Kahan, New Path, supra note 12, at 2477.

21. I will refer to the "new path of deterrence" and to "the social influence conception of deterrence" interchangeably, as does Kahan. However, I distinguish both of these terms from social norm theory. The new path of deterrence is an application of social norm theory to the criminal law. The distinction is an important one.

22. Skogan, Disorder ANd Decline, supra note 9, at 75; see also Wesley G. Skogan, Disorder and Community Decline: Final Report to the National Institute of Justice (Mar. 31, 1987) [hereinafter Skogan, Final Report]. 
disorder, a cluster of five Newark neighborhoods exert excessive influence on the statistical findings. When those five Newark neighborhoods are set aside, the relationship between robbery victimization and disorder disappears. Accordingly, the data do not support the broken windows hypothesis.

Social norm proponents advance a second empirical argument in support of order-maintenance policing, namely the precipitous decline in crime rates in New York City. ${ }^{23}$ The conventional explanations for the drop in crime, they argue, do not account for the magnitude of the drop in relation to other large cities. As we speak, however, there is a hotly contested debate raging among criminologists, legal scholars, policy-makers, journalists, and other experts over the causes of the decline in crime in New York City and nationally. ${ }^{24}$ I review the various leading explanations and argue that it is far too simplistic to suggest that the quality-of-life initiative explains the extent of the decline of the crime rate in New York City.

The social influence conception of deterrence also does not withstand scrutiny at the theoretic level. The theory relies on a traditional sociological approach that does not sufficiently question the categories underlying the sociological analysis, or the relationship between its prescriptions and those categories. The theory's approach is similar to that of Emile Durkheim, ${ }^{25}$ but ignores, I argue, some of the most insightful intellectual developments of the twentieth century. As a result, the set of policies emerging along

23. See Kahan, Social Influence, supra note 12, at 369.

24. See 88 J. CrIm. L. \& CrImINology, supra note 11 (containing articles discussing declining crime rate); Butterfield, supra note 11 (reporting on the conference). As a recent cover story in U.S. News \& World Report acknowledges, "the national causes of the improvement remain mysterious." Witkin, supra note 7, at 28. The cover story rehearses the different explanations that have been offered for the national decline in crime - the economy, crime prevention programs, decline in battered wives, increased prison populations, new policing strategies - and ultimately argues that the decline in crack use is the leading factor contributing to the national decline. See also Geoffrey A. Campbell, Putting a Crimp in Crime: Experts Differ Over Reasons for Falling Rates of Serious Offenses, A.B.A. J., May 1997, at 24 .

25. The strong resemblance between the social influence conception of deterrence and Durkheim's sociology is by no means accidental. Social norm proponents explicitly trace the notion of constructivism that underlies social meaning to modern social theory and the work of Emile Durkheim. See, e.g., Lessig, supra note 16, at 949. (Lessig appends the following footnote: "It is constructivism that defines modern social theory." Id. at 949 n.19. The footnote continues, "Emile Durkheim is one start: "[S]ocial reality is constructed by the operation of the society itself. . . Social facts are the product of the group life of the total operation of a society." Id. (quoting JOSEPH BENSMAN \& ROBERT LILIENFELD, CRAFT AND CoNsciousness 157 (1973) (alteration in original))). See also Kahan, supra note 18, at 59496 (discussing the expressive dimension of punishment which explicitly traces back to the work of Emile Durkheim). 
the new path of deterrence are too limited. The policies do not sufficiently challenge our narrow way of conceptualizing crime.

Running through the social influence explanation and the broken windows theory is a recurrent and pervasive dichotomy between, what we could call in vulgar terms, honest people and the disorderly; between "committed law-abiders" 26 and "individuals who are otherwise inclined to engage in crime";27 between "families who care for their homes, mind each other's children, and confdently frown on unwanted intruders" 28 and "disreputable or obstreperous or unpredictable people: panhandlers, drunks, addicts, rowdy teenagers, prostitutes, loiterers, the mentally disturbed."29 Hand-in-hand with this set of categories is another ubiquitous dichotomy between order and disorder; between "norms of orderliness" 30 and "[p]ublic drunkenness, prostitution, aggressive panhandling and similar behavior"; 31 between a "stable neighborhood" 32 and "an inhospitable and frightening jungle."33

The social influence conception of deterrence is grounded on these categories. The mechanisms of social influence assume these fixed identities because disorder operates on honest people and on the disorderly in different ways. Neighborhood disorder influences honest people to move out of the neighborhood or to lock themselves in their homes, but it influences the disorderly and especially criminals to move into the neighborhood and commit crimes.

These categories, however, do not have a pre-existent fixed reality, independent of the techniques of punishment implemented by the quality-of-life initiative. In other words, they do not pre-date the policing strategy. To the contrary, the category of the disorderly is itself a reality produced by the method of policing. It is a reality shaped by the policy of aggressive misdemeanor arrests. It is the product of a technique of punishment that combines several different historical modalities, including classical strategies of excessive force and modern disciplinary mechanisms like surveillance and spatial control. Michel Foucault's study, Discipline and Pun-

26. Kahan, Social Influence, supra note 12 , at 371 .

27. Id. at 371.

28. Wilson \& Kelling, supra note 2, at 31.

29. Id. at 30.

30. Kahan, Social Influence, supra note 12, at 371.

31. Id. at 370 .

32. Wilson \& Kelling, supra note 2, at 31.

33. Id. at 31-32. 
ish, ${ }^{34}$ details these techniques of punishment, and it is there, I suggest, that we should turn to overcome the problems with the Durkheimian approach - first, by rehearsing Foucault's analysis, but second, and more importantly, by refining his analysis.

The techniques of punishment that comprise the quality-of-life initiative create the disorderly person as an object of suspicion, surveillance, control, relocation, micromanagement, and arrest. According to the unwritten rules of a Newark police officer enforcing order, "[d]runks and addicts could sit on the stoops, but could not lie down. People could drink on side streets, but not at the main intersection. Bottles had to be in paper bags. Talking to, bothering, or begging from people waiting at the bus stop was strictly forbidden." 35 The fine art of policing creates the disorderly as a person with a full biography of habits, inclinations and desires. It simultaneously creates the disorderly as an object of surveillance and control.

The disorderly is closely analogous to the delinquent, in Foucault's work, the end product of the penitentiary system. But the disorderly also differs in important ways from the delinquent. $\mathrm{He}$ is not coddled, he is not reformed, he is not part of the psychotherapeutic project of rehabilitation. The disorderly is, instead, watched, controlled, relocated, and, ideally, excluded from the neighborhood. The disciplinary techniques captured by the quality-of-life initiative operate on an axis of order and disorder, rather than on the axis of psychotherapeutic rehabilitation.

Order-maintenance policing helps create the category of the disorderly and this, in turn, facilitates the very policy of aggressive arrests for minor disorderly conduct. Once the category is in place, there is little else to do but crack down on the disorderly. Who in their right mind, after all, would side with people who urinate in the street, break windows, aggressively accost passers-by, or vandalize other people's property? The category triggers an aggressive response, even absent evidence supporting the broken windows theory.

At the same time, the category overshadows the numerous costs associated with the new policing strategy. Order maintenance in New York City has been achieved, in large part, by means of a fifty percent increase in misdemeanor arrests - up from 133,446 in 1993

34. Michel Foucault, Discipline and Punish (Alan Sheridan trans., 1979) (translation of Michel Foucault, Surveiller et Punir (1975)).

35. Wilson \& Kelling, supra note 2, at 30. 
to 205,277 in $1996 .{ }^{36}$ Those arrests can be quite an ordeal: being arrested, handcuffed, transported, booked, often strip-searched, and spending the night in jail is an experience that many of us, readers of this Article, have had the good fortune to avoid. ${ }^{37}$ The quality-of-life initiative has been accompanied by a significant increase in the number of complaints of police brutality. The Civilian Complaint Review Board in New York City received 5,550 and 4,816 complaints of police brutality for 1996 and 1997, respectively, up from 3,580 complaints in 1993. ${ }^{38}$ Moreover, a law enforcement strategy that emphasizes misdemeanor arrests has a disproportionate effect on minorities - not necessarily in relation to the racial composition of misdemeanor offenders but simply in relation to the racial composition of the community. The brute fact is that the decision to arrest for misdemeanors results in the arrest of many minorities. In cities in the United States, for example, $46.4 \%$ of persons arrested for vagrancy and $58.7 \%$ of persons arrested for suspicion in 1995 were black although the population inside metropolitan areas was approximately $13 \%$ African-American. ${ }^{39}$ Ordermaintenance policing may also delegate the power to define order and disorder to police officers and designated community members in a manner inconsistent with our conception of democratic theory or constitutional principles. And the costs of arrest and prosecution of minor misdemeanor offenses may add up to a considerable investment. ${ }^{40}$ These are some aspects of order-maintenance policing that are not being heard in today's euphoria, in large part because of the category of the disorderly underlying the social influence conception of deterrence. They suggest that a much stronger empirical showing is needed before we proceed down the new path of deterrence.

36. See Letter from Michael Farrell, Deputy Commissioner, New York Police Department, to Jenna Karadbil (Apr. 13, 1998) (on file with author).

37. The ordeal of arrest has been described in Cooper, supra note 11; Lipsyte, supra note 11; Purdy, supra note 11; Sontag \& Barry, supra note 11.

38. See Fax from Sherman Jackson of the CCRB to Author (June 17, 1998) (including statistics from the New York City Civilian Complaint Review Board).

39. See Bureau of Justice Statistics, U.S. Dept. of Justice, Sourcebook of CrimiNAL Justice STatistics-1996, at 386 tbl.4.12 [hereinafter Sourcebook OF Criminal JusTICE STATISTICS-1996] (listing racial breakdown of arrests in all cities, including cities with less than 10,000 inhabitants, see id., app. 3 at 595); Bureau of THE Census, U.S. DePT. OF Commerce, 1990 Census of Population: General Population CharacteristicsUnited States, at 7 tbl. 5 [hereinafter 1990 Census of Population] (listing racial breakdown inside metropolitan areas, defined as including urbanized areas with a minimum population of 50,000 , see id. at A-8).

40. See Deborah L. Rhode, Who is the Criminal?, NAtL. L.J., Sept. 25, 1995, at A22. 
I should emphasize at the outset that I am extremely sympathetic with the motivation behind the new path of deterrence. Its primary motive, Kahan explains, is political, not conceptual. "By focusing on how law can be used to regulate norms, the new deterrence scholarship can be used to identify morally acceptable and politically feasible alternatives to the severe punishments that dominate contemporary criminal law."41 I share Kahan's motivation. New York City's quality-of-life initiative, however, does not fulfill that aspiration.

This Article is part of a larger project, a project with at least three important goals. The first is to explore critically the current application of social norm theory to the criminal law and offer an alternative to the new path of deterrence. My purpose here is not to critique social norm theory tout court. That would be a much larger enterprise. Instead, my more limited goal is to critique the specific application of social norm theory to the criminal law that characterizes the new path of deterrence. $42 \mathrm{My}$ second goal is to integrate social and political theory into the discussion of public policy. One of the great contributions of social norm proponents has been to integrate sociology into the public policy discussion of crime. What is still missing is a discussion of the theory underlying that sociology. Kahan's sociology, in my opinion, is not adequately theorized, and this accounts for the dissonance between his desire to find alternative policies to incarceration and his endorsement of

41. Kahan, New Path, supra note 12, at 2478.

42. I should say, in this context, that I have agonized over the question of whether to refer to Kahan as a "social norm proponent" and thereby to group him together with Lawrence Lessig, Robert Ellickson, and others. On occasion, I have been tempted to suggest, instead, that Kahan's writings on order-maintenance policing are simply at odds with social norm theory - that Kahan misappropriates the theory of social meaning by turning societal order into a natural, or necessary, or uncontested social understanding. As Lawrence Lessig has written, "The more they appear natural, or necessary, or uncontested, or invisible, the more powerful or unavoidable or natural social meanings drawn from them appear to be." Lessig, supra note 16, at 960-61. I have been tempted, at times, to argue that social norm theorists, such as Lessig, would reject Kahan's argument about order-maintenance policing because it fails to appreciate the contingent and constructed nature of societal order, as well as the way in which the social meanings associated with societal order construct the population into law abiders and criminals, thereby naturalizing order-maintenance policing. But, for better or worse, I have resisted that temptation. I am not prepared to impute to Lessig or others, without a text, any opposition to the quality-of-life initiative and its policy of aggressive misdemeanor arrests. See id. at 1039-40 (Lessig discusses one aspect of the quality-of-life initiative to illustrate a change in social meaning. He does not, however, indicate one way or the other whether he supports that specific regulation of social meaning.) For that reason, I have instead respected the self-identified boundaries of the social norm movement and interpreted Kahan as applying social norm theory to the criminal law. Thus, I am not arguing here that Kahan is unfaithful to social norm theory. Nor am I critiquing social norm theory writ large. I am, instead, addressing the narrower issue of Kahan's application of social norm theory to crime and punishment. In other words, I am addressing the social influence conception of deterrence. 
a straightforward policy of aggressive misdemeanor arrests and detention - between his aspiration to use social norms to regulate criminal behavior and his endorsement of police enforcement of misdemeanor laws. This Article seeks to remedy that deficiency by initiating a debate on the underlying social and political theory and relating that debate to concrete public policies. Third, this Article seeks to deploy constructively the writings of Michel Foucault. I suggest that he offers the most perceptive critique of Durkheim and a path to reconstruct public policy. Foucault's work is often vilified in the legal academy because of its association with the moment of deconstruction. This Article is a corrective. I propose here a reading of Foucault that affirmatively helps to transcend the limitations of the new path of deterrence. It is Foucault's critique of the sociological approach underlying the social influence conception of deterrence that exposes its limits and paves the way for a thicker concept of the subject. With this thicker concept, I propose an alternative approach to thinking about criminality and I suggest specific policy implications. My last goal, then, is to deploy Foucault for a positive public policy agenda.

\section{Order-Maintenance Policing: A CRitical Description}

\section{A. Background}

Order-maintenance policing is a law-enforcement strategy that seeks to create public order by aggressively enforcing laws against public drunkenness, loitering, vandalism, littering, public urination, panhandling, prostitution, and other minor misdemeanors. It is one variation of community policing, ${ }^{43}$ a variation that emphasizes po-

43. "Community policing," at its most abstract or general level, stands for the idea that police officers can prevent crimes by integrating themselves into the community, rather than by merely responding to emergency calls. Community policing comes in a number of different variations, ranging from the type of order-maintenance policing that emphasizes arrest (discussed in this Article) to the style of community policing that withholds enforcement as a way to build community contacts. See Wesley Skogan, Community Policing, Chicago STYLe (1997); Jonathan Eig, Eyes on the Street: Community Policing in Chicago, 29 AMERICAN ProspeCT 60 (Nov.-Dec. 1996). Community policing writ large has revolutionized policing both in the United States and abroad over the past fifteen years. In a recent National Institute of Justice survey of police departments, more than $80 \%$ of police chiefs polled stated that they were either implementing or intended to implement some aspect of community policing. See Todd McEwen, National Institute of Justice, National Assessment Program: 1994 Survey Results 27 (1995); see also Sean P. Murphy, Community Policing Gaining Popularity, Boston Globe, Dec. 29, 1992, at 17. The popularity and success of community policing is attributable, in part, to the vagueness of the definition. Not all experiments with community policing, however, have met with equal success. See Wesley G. Skogan, The Impact of Community Policing on Neighborhood Residents, in ThE CHALlenge of Community Policing 180 (Dennis P. Rosenbaum ed., 1994) ("There are ample examples of failed experiments and cities where the concept has gone awry."). 
lice presence and arrests. Order-maintenance policing traces its origins to the broken windows theory, first articulated in James Q. Wilson and George L. Kelling's article, Broken Windows, which appeared in the Atlantic Monthly in 1982.44 The hypothesis of the broken windows theory is that minor disorder in a neighborhood, if left unchecked, will result in increased serious crime, and, therefore, that eliminating minor disorder will have a deterrent effect on major crime.

Order-maintenance policing has been implemented in New York City during the administration of Mayor Rudolph Giuliani and has come to be known as "the quality-of-life initiative." It is a policy of zero tolerance toward minor misdemeanor offenses, or what are called "quality-of-life crimes." Former New York City Police Commissioner William Bratton, the principal architect of the quality-of-life initiative, cites the Broken Windows article as the main source of his ideas. ${ }^{45}$

Order-maintenance policing is also one of the principal policy recommendations emerging along the new path of deterrence. ${ }^{46}$ Social norm proponents specifically endorse New York City's quality-of-life initiative as a successful illustration of order-maintenance policing. ${ }^{47}$ According to Dan Kahan, the success of New York City's strategy can be explained in terms of the social influence conception of deterrence. Kahan relies heavily on the broken windows theory, ${ }^{48}$ suggesting that it is social influence in action. ${ }^{49}$

\section{B. The Broken Windows Essay}

The Broken Windows essay is premised on the idea that "disorder and crime are usually inextricably linked, in a kind of develop-

44. Wilson \& Kelling, supra note 2.

45. See William J. Bratton, The New York City Police Department's Civil Enforcement of Quality-of-Life Crimes, 3 J.L. \& Poly. 447 (1995); see also Cullen, supra note 3, at 12; Fred Kaplan, Looks Count, Boston GloBe, Jan. 19, 1997, at E1.

46. See, e.g., Kahan, New Path, supra note 12, at 2488; Kahan, Social Influence, supra note 12, at 368-73; see also Ellickson, supra note 16, at 1173, 1200-02, 1247-48 (arguing that a city's best approach to dealing with panhandlers and skid rows is to have an informal zoning system that is informally enforced by the police - "that is, to employ trustworthy police officers and to give them significant discretion" - in effect, similar to the quality-of-life initiative); $c f$. Livingston, supra note 16, at 581-91 (advocating implicitly measures to manage police discretion in the context of the quality-of-life initiative).

47. See, e.g., Kahan, New Path, supra note 12, at 2488; Kahan, Social Influence, supra note 12 , at $368-73$.

48. See Kahan, Social Influence, supra note 12, at 368-73. Other social norm proponents also rely extensively on the broken windows theory. See, e.g., Ellickson, supra note 16, at 1171-73, 1177-79, 1182; Livingston, supra note 16, at 581-91.

49. See Kahan, Social Influence, supra note 12, at 369. 
mental sequence."50 According to Wilson and Kelling, minor disorders (like littering, loitering, public drinking, panhandling, and prostitution) if tolerated, produce an environment that is likely to attract crime. They signal to potential criminals that delinquent behavior will not be reported or controlled - that no one is in charge. One broken window, left unrepaired, invites other broken windows. These progressively break down community standards, leaving the community vulnerable to crime.

In the essay, disorder breeds crime in a highly scripted manner: A stable neighborhood of families who care for their homes, mind each other's children, and confidently frown on unwanted intruders can change, in a few years or even a few months, to an inhospitable and frightening jungle. A piece of property is abandoned, weeds grow up, a window is smashed. Adults stop scolding rowdy children; the children, emboldened, become more rowdy. Families move out, unattached adults move in. Teenagers gather in front of the corner store. The merchant asks them to move; they refuse. Fights occur. Litter accumulates. People start drinking in front of the grocery; in time, an inebriate slumps to the sidewalk and is allowed to sleep it off. Pedestrians are approached by panhandlers.

At this point it is not inevitable that serious crime will flourish or violent attacks on strangers will occur. But many residents will think that crime, especially violent crime, is on the rise, and they will modify their behavior accordingly. They will use the streets less often, and when on the streets will stay apart from their fellows, moving with averted eyes, silent lips, and hurried steps. ...

Such an area is vulnerable to criminal invasion. Though it is not inevitable, it is more likely that here ... drugs will change hands, prostitutes will solicit, and cars will be stripped. That the drunks will be robbed by boys who do it as a lark, and the prostitutes' customers will be robbed by men who do it purposefully and perhaps violently. ${ }^{51}$

This script privileges order over disorder and this hierarchy is refracted throughout the essay. A typical community, for instance, is composed of citizens or "decent folk" on the one hand, and criminals and "disorderly people" on the other. 52 The disorderly people include "disreputable or obstreperous or unpredictable people: panhandlers, drunks, addicts, rowdy teenagers, prostitutes, loiterers, the mentally disturbed." 53 They are closely associated with vices, like drinking, prostitution, littering, and begging: the "illsmelling drunk" or the "importuning beggar." 54 They are also often

50. Wilson \& Kelling, supra note 2, at 31.

51. Id. at 31-32.

52. See id. at 30.

53. Id.

54. Id. at 34. 
associated with youth: the rowdy children, the fighting teenagers, the "unattached adults."55

This opposition of orderly and disorderly people cuts across a further, pervasive insider-outsider dichotomy, in effect producing two categories of troublemakers, the disorderly insiders, who need to be controlled, and the disorderly outsiders, who need to be excluded. Schematically, the essay can be represented as follows:

REGULARS

ORDERED DISORDERED decent folk

drunks and derelicts
STRANGERS visitors criminals

According to the essay, it is "outsiders" 56 or "strangers" 57 who commit crimes. "Regulars," 58 on the other hand, tend not to cause real problems. So, for instance, the essay recounts the views of a patrol officer, fictitiously named Kelly, who is assigned a beat in downtown Newark in a controlled experiment regarding community policing:

The people were made up of "regulars" and "strangers." Regulars included both "decent folk" and some drunks and derelicts who were always there but who "knew their place." Strangers were, well, strangers, and viewed suspiciously, sometimes apprehensively. The officer - call him Kelly - knew who the regulars were, and they knew him. As he saw his job, he was to keep an eye on strangers, and make certain that the disreputable regulars observed some informal but widely understood rules. Drunks and addicts could sit on the stoops, but could not lie down. People could drink on side streets, but not at the main intersection. Bottles had to be in paper bags. Talking to, bothering, or begging from people waiting at the bus stop was strictly forbidden. If a dispute erupted between a businessman and a customer, the businessman was assumed to be right, especially if the customer was a stranger. If a stranger loitered, Kelly would ask him if he had any means of support and what his business was; if he gave unsatisfactory answers, he was sent on his way. 59

Kelly's task, as he saw it, was to regulate the disorderly regulars and exclude the disorderly strangers.

The insider-outsider dichotomy is also reflected by the recurring notion of "criminal invasion,"60 reinforcing the idea that crime comes from outside the community. The essay manages to sustain

\footnotetext{
55. $I d$. at 32 .

56. Id. at 36 .

57. Id. at 30 .

58. Id.

59. Id.

60. Id. at 32-33.
} 
this fiction by excluding delinquents. The insider teenager, for instance, who lives in a housing project and becomes, a gang member, simply loses his insider status. Though he may continue to live in the projects, he is no longer a "project resident," no longer a "citizen," and no longer has a legitimate voice. ${ }^{61}$ He no longer has a claim to membership in the community - especially in the face of competing claims by orderly residents who are struggling to "reassert control over [their] turf."62

Broken Windows is premised, then, on a number of shared understandings about the privilege of order over disorder, and insider over outsider; about the likelihood of criminal invasion in disorderly neighborhoods; and about the suspicious nature of the unattached adult. It is premised on categorical distinctions between disorderly people and law abiders. It reflects an aesthetic of orderliness, cleanliness, and sobriety. And, on the basis of these categories, it weaves a theory of deterrence. The message is clear: fighting disorder will deter serious crime.

\section{The Social Influence Conception of Deterrence}

The social influence conception of deterrence owes a lot to the broken windows theory. It borrows much of the sociological explanation. It also adopts the underlying categories of the disorderly and law abiders, and of order and disorder. To fully appreciate this, however, it is worth reviewing the social influence conception of deterrence in slow motion, so that all of its terms - social norm, social meaning, social influence, social construction - do not run into each other. Kahan writes that " $[t]$ he effect of disorder on crime can be understood in terms of the effect that social meaning has on the mechanisms of social influence."63 Let's take this frame by frame.

\section{Social Meaning}

The social meaning in question is the meaning of order and disorder. Order means that the community cares about its neighborhood and is prepared to enforce norms of orderliness. The corollary is that disorder means no one cares. So, for instance, Kahan writes that "[d]isorder is . . pregnant with meaning: Public

61. See id. at 35 .

62. Id. at 33. "What the police in fact do," the essay reads, "is chase known gang members out of the project." Id. at 35 . The authors do the same when they exclude gang members from the category of "project residents."

63. Kahan, Social Influence, supra note 12, at 370 (emphasis added). 
drunkenness, prostitution, aggressive panhandling and similar behavior signal ... that the community is unable or unwilling to enforce basic norms." 64

Social norm proponents suggest that "[s]ome social meanings are constructed." 65 Those that are, are socially constructed through the interrelationship of action and context - the context being certain expectations or understandings that are often unquestioned. Social meanings are "the frameworks of understanding within which individuals live; a way to describe what they take or understand various actions, or inactions, or statuses to be; and a way to understand how the understandings change." 66 When these understandings are uncontested, the related social meanings acquire more power and appear unavoidable. ${ }^{67}$

\section{Social Influence}

Social meanings can have social influence, which is to say that they can influence the behavior of individuals in society. In the broken windows context, the social meaning of disorder influences the disorderly to commit crimes and law abiders to leave the neighborhood. Conversely, the social meaning of order influences the disorderly not to follow their inclination to commit crime and law abiders to walk more freely in the streets at night. It is in this sense that Kahan writes, "Visible disorder . . . tells individuals that their" own forbearance is unlikely to be reciprocated.... The meaning of disorder can also influence the behavior of committed law-abiders in a way that is likely to increase crime."68 Conversely, Kahan explains that "[w]hen citizens obey norms of orderliness - and when authorities visibly respond to those who don't - onlookers see that the community is intolerant of criminality. This message counteracts the inferences that point social influence in the direction of crime." 69

64. Id. (emphasis added).

65. Lessig, supra note 16, at 949; see also id. at 949 n.19.

66. Id. at 952 (emphasis omitted). Social meaning is somewhat similar, then, to what Clifford Geertz refers to as culture - the code through which we interpret each others' actions. See ClifFord GeERTz, Thick Description: Toward an Interpretive Theory of Culture, in THE INTERPRETATION OF CULTURES 10-13 (1973).

67. "When these understandings or expectations become uncontested and invisible, social meanings derived from them appear natural, or necessary. The more they appear natural, or necessary, or uncontested, or invisible, the more powerful or unavoidable or natural social meanings drawn from them appear to be." Lessig, supra note 16, at 960-61 (internal citations omitted).

68. Kahan, Social Influence, supra note 12, at 371 (emphasis added and omitted).

69. Id. 


\section{Social Norms}

To take advantage of social influence, the social norm of orderliness has to be enhanced. The idea is, as the previous passage suggests, that social influence may sway citizens to "obey norms of orderliness."70 The norm of orderliness operates through social meaning to influence the kind of good behavior on the part of disorderly and honest people that will reduce crime. Social influence then has a feedback effect on social norms, influencing people to act in a more orderly manner. In this way, changing a social meaning may change social norms.

Lawrence Lessig illustrates this point in his discussion of New York City's various approaches to panhandling. During the late 1980 s and early 1990 s, the city sought to ban panhandling by passing a law prohibiting loitering for the purpose of begging. ${ }^{71}$ That law was struck down by the federal courts under the First Amendment and, as a result, was not given the chance to change the social meaning associated with giving to panhandlers. ${ }^{72}$ The transit authority then took a different tack and, through an advertising campaign, communicated to passengers that it was wrong to give money to panhandlers because it made them less likely to go seek help. That campaign, Lessig reports, was effective and succeeded in changing the social meaning associated with giving to beggars. Lessig writes:

Before the Transit Authority started this poster campaign, the refusal of a passenger to give any money to a panhandler had a relatively unambiguous meaning - identifying the passenger as coldhearted, or cheap, or uncaring. Thus, the refusal to give was costly for the passenger. But the Authority's poster campaign ambiguated this meaning. Now, the refusal could either be because the passenger is coldhearted, etc., or because the passenger is concerned to do what is best for the panhandler. What is best for the panhandler is for the passenger to say no to the panhandler. Thus the posters succeeded in making it less costly for the passers,er not to give to the panhandler by ambiguating the social meanin, of a refusal to give. ${ }^{73}$

70. Id. (émphasis added).

71. See Lessig, supra note 16, at 1039.

72. This account is somewhat simplified. In fact, there was a ban on panhandling in the subways. The federal courts upheld that ban, and it continued in effect throughout the period. See Supren:e Cnurt Refuses to Hear Challenge to Anti-Begging Law, N.Y. L.J., Nov. 27, 1990, at 1. Lessig does recognize this in a footnote. See Lessig, supra note 16, at 1040 n.329. What it suggests, though, is that a full account of the change in social meaning would have to take into consideration whether it was the prohibition or the education campaign that affected the amount of panhandling. This fuller account would have to look at arrest rates for panhandling in the subways, deployment of police force in the subways and the effect of that deployment on the behavior of subway riders.

73. Lessig, supra note 16 , at 1040. 
By changing the social meaning (through ambiguation), the transit authority attempted to change the patterns of giving to panhandlers and thereby reduce the number of panhandlers. ${ }^{74}$

The relationship between social meaning, social influence and social norms is illustrated in the following figure:

FIGURE 1:

The Social Influence Conception of Deterrence

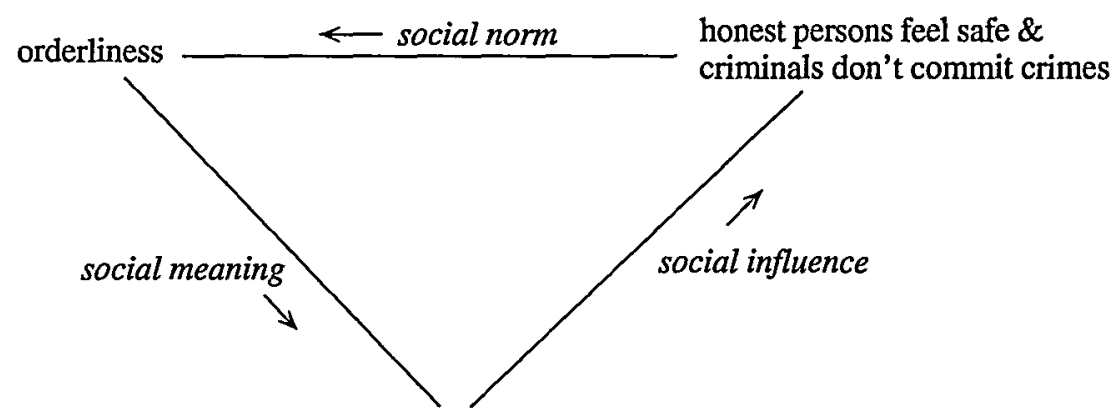

community is in control \& criminals are in check

In the context of order-maintenance policing, this suggests that, by encouraging the social norm of orderliness, major crime may decline because (a) the social meaning of orderliness is that the disorderly cannot get away with crime and (b) this social meaning will favorably influence the behavior of the disorderly and law abiders. According to Kahan, this is the best explanation for the success of New York City's quality-of-life initiative.

\section{The Lack of Social Science Evidence}

The broken windows theory and the social influence conception of deterrence - the two theoretic justifications underlying ordermaintenance policing and, more specifically, the quality-of-life initiative - rest on a claim of deterrence. The theories suggest that, by eliminating minor misdemeanors and disorderly behavior, a neighborhood can deter serious crime. Claims of deterrence are, of course, empirical in nature. Proponents of order-maintenance policing principally deploy two arguments in support of the deterrence claim. The first is Wesley Skogan's study, Disorder and Decline:

74. In conversation, Toni Massaro suggested, correctly I believe, that the social meaning was always ambiguous, as evidenced by the fact that few people gave money before the media campaign anyway. 
Crime and the Spiral of Decay in American Neighborhoods. ${ }^{75}$ Kahan relies heavily on Skogan's study, arguing that it "supplies empirical support for the 'broken windows' hypothesis."76 George Kelling, the co-author of Broken Windows and Fixing Broken Windows, similarly states that Skogan "empirically verif[ied] the 'Broken Windows' hypotheses."77 According to Kelling, Skogan demonstrated "a direct link between disorder and crime: in other words, 'disorder and crime problems go together in a substantial way." "78 The second argument in support of the deterrent effect is that crime in New York City has declined at a far greater pace than most anywhere else in the country, and, therefore, that the difference must be attributable to the new policing strategy. "The forces conventionally assumed to drive crime rates don't explain much," Kahan argues. "What has changed significantly is New York's lawenforcement strategy." 79 Neither of these two arguments, however, is persuasive. Skogan's study does not verify the broken windows hypothesis, and the causes of the decline in crime in New York City are far too contested to lend themselves to such simplistic analysis.

\section{A. Replicating Skogan's Study}

Working with Skogan's data, which is available through the Inter-University Consortium for Political and Social Research at the University of Michigan, I was able to assess his data and replicate his analysis. ${ }^{80} \mathrm{I}$ found that his data do not support the claim that crime is related to disorder. The data in fact suggest that certain crimes, like purse snatching, pocket-picking, and rape are not related to disorder at all. Certain crimes, like physical assault and burglary, are significantly related to disorder; however, the statistical relationship vanishes when neighborhood poverty, stability, and race are taken into account. Finally, robbery is also significantly

75. Skogan, Disorder and Decirne supra note 9, at 75; Wesley G. Skogan, Disorder and Community Decline in Forty Neighborhoods of the United States, 1977-1983, in INTERUNIVERSITY CONSORTIUM FOR POL. AND SOC. RES. (ICPSR No. 8944) (1988) [hereinafter ICPSR Codebook]; Skogan, Final Report, supra note 22.

76. Kahan, Social Influence, supra note 12, at 369. See also Kahan, New Path, supra note 12 , at $2488 \&$ n.62.

77. Kelling \& Coles, supra note 10, at 24.

78. Id. at 25 .

79. Kahan, Social Influence, supra note 12, at 368.

80. I thank and commend Wesley Skogan for making his data publicly available through the ICPSR, without which it would be nearly impossible to replicate his work. See Wesley G. Skogan, Disorder and Community Decline in Forty Neighborhoods of the United States, 19771983 (last modified Apr. 20,1998) <http://www.icpsr.umich.edu/cgi/ab.prl?file=8944> [hereinafter Skogan's Data]. 
related to disorder, but that statistical relationship disappears when the five Newark observations are set aside and the same explanatory variables are held constant. Overall, my reservations about the data set and certain design decisions undermine my confidence in Skogan's conclusions.

\section{Skogan's Study: Method and Findings}

On the basis of data collected in five separate studies between 1977 and 1983, Skogan found, inter alia, that neighborhood disorder had a statistically significant relationship with the level of neighborhood robbery victimization. Skogan discusses and verifies a number of other hypotheses in his work - for instance, that there is a link between disorder and fear of crime victimization ${ }^{81}$ as well as a link between disorder and perception of crime problems ${ }^{82}$ but in this Article I will treat exclusively the disorder-crime nexus.

Skogan's data come from five previously existing studies, which Skogan aggregates and merges to produce neighborhood-level data of disorder, crime levels, and socioeconomic factors. ${ }^{83}$ The five existing data sets consist of 13,000 personal and telephone interviews conducted between 1977 and 1983.84 The respondents were residents of forty different neighborhoods in the following six cities: Chicago, Newark, Houston, Philadelphia, San Francisco, and Atlanta. The respondents were selected at random, using randomdigit-dialing telephone techniques for the telephone interviews and random selection from address lists for the personal interviews. ${ }^{85}$

Skogan performs two analyses to assess the disorder-crime nexus. First, he regresses the rate of robbery victimization on the level of disorder. Second, he regresses the rate of robbery victimi-

81. See SKogan, Disorder and Decline, supra note 9, at 77. Skogan acknowledges, however, that fear of crime is more strongly correlated with crime than with disorder and that, when levels of crime are controlled for, "the relationship between disorder and fear no longer is significant." Id. at 77.

82. See id. at 74. Skogan also argues that this "document[s] that disorder and crime problems go together in a substantial way." Id. The reliability of this finding and the validity of the conclusion are somewhat questionable given that the data for both variables were obtained by interviewing the same people. The same residents were asked if there is disorder in their neighborhood and if they perceive that there is a crime problem in their neighborhood. It seems, though, that residents who believe there is a crime problem in their neighborhood will also perceive their neighborhood as disorderly. Perception of crime problems and disorder seem to go hand-in-hand. The fact that there is a strong correlation may be due to the fact that the data were collected from the same individuals.

83. See Skogan, Final Report, supra note 22, at 8.

84. See id. at 6, 97.

85. See Skogan, Disorder and Decline, supra note 9, at 190; Skogan, Final Report, supra note 22, at 99 fig.25 (listing random-digit-dialing for at least two of three phone interview surveys). 
zation on the level of disorder taking into account the level of poverty, residential stability, and the racial composition of the neighborhoods.

\section{a. The Disorder-Robbery Regression Analysis}

With regard to the simple regression of robbery victimization on the level of disorder, Skogan finds that "levels of crime victimization were strongly related $(+.80)$ to levels of disorder in the 30 areas for which robbery victimization was measured."86 Skogan does not report his coefficients, but does include a graph showing the regression line running through the observations on a scatter-plot ( $\mathrm{x}$-axis level of disorder; $y$-axis percent victims of robbery). ${ }^{87}$ The scatterplot communicates a positive relationship between disorder and robbery victimization.

\section{b. The Other-Explanatory-Variables Analysis}

Skogan then conducts further analysis to take into account the effect of neighborhood poverty, stability, and race. The measures of poverty and stability are indices composed of weighted factors like average length of residence, percent rental dwellings, and percent incomes over $\$ 20,000.88$ Race is measured by the variable corresponding to respondents' answers about their race, and reflects the percentage of minorities in the community. ${ }^{89}$ Skogan finds that the correlation between robbery victimization and disorder remains high $(+.54)$ even when these three other explanatory variables are taken into account. 90

\section{c. Skogan's Conclusion}

Skogan prefaces his findings with a significant caveat. In effect, he begins by saying that the data shed little light on the causal relationship. He writes:

Ironically, the data from the 40 neighborhoods cannot shed a great deal of light on the details of the relationship between disorder and crime, for the measures all go together very strongly. With only 40

86. Skogan, Final Report, supra note 22, at 53; see also SkogAn, Disorder AND DECLINE, supra note 9, at 73 .

87. See Skogan, Disorder ANd Decline, supra note 9, at 74 fig.4-2. I replicate and reproduce this scatter-plot infra.

88. See id. at 192 tbl.A-3-1; Skogan, Final Report, supra note 22, at 22 fig.4.

89. See ICPSR Codebook, supra note 75, at 14; Skogan, Final Report, supra note 22, at 25-29.

90. See Skogan, Disorder ANd Decline, supra note 9, at 73-74; Skogan, Final Report, supra note 22 , at 53. 
cases to untangle this web, the high correlation between measures of victimization, ratings of crime problems, and disorder make it difficult to tell whether they have either separate "causes" or separate "effects" at the area level. ${ }^{91}$

But, in response to the broad question "Does Disorder Cause Crime?," Skogan ultimately concludes: "These data support the proposition that disorder needs to be taken seriously in research on neighborhood crime, and that both directly and through crime it plays an important role in neighborhood decline. 'Broken windows' do need to be repaired quickly."92

Despite his initial caveat, then, Skogan asserts that there is a causal relationship between levels of neighborhood disorder and rates of crime, and so concludes:

The evidence suggests that poverty, instability, and the racial composition of neighborhoods are strongly linked to area crime, but a substantial portion of that linkage is through disorder: their link to area crime virtually disappears when disorder is brought into the picture. This too is consistent with Wilson and Kelling's original proposition, and further evidence that direct action against disorder could have substantial payoffs. ${ }^{93}$

Not surprisingly, Skogan's study has been consistently interpreted by the order-maintenance proponents as establishing the disordercrime nexus.

\section{Skogan's Findings: A Replication}

Before turning to a critique of Skogan's study, I will first set forth his findings in greater detail. In order to do this, it is necessary to replicate the study because Skogan does not provide most of the quantities of interest in either the more technical Final Report or in his book Disorder and Decline. ${ }^{94}$

\section{a. The Disorder-Robbery Regression}

Although Skogan does not share his regression coefficients or standard errors, it is possible to estimate them by replication, and verify them by comparing the scatter-plot that he published in Disorder and Decline (Figure 4-2 at page 74) with the one that I obtain using his data. The scatter-plot that I obtain is, in all pertinent re-

91. Skogan, Disorder AND DeCline, supra note 9, at 73; see also Skogan, Final Report, supra note 22, at 49.

92. SKogan, Disorder ANd Decline, supra note 9, at 75; see also Skogan, Final Report, supra note 22 , at 53 (finding "a strong tendency for crime and disorder to 'go together").

93. Skogan, Disorder and Decline, supra note 9, at 75.

94. See Skogan, Final Report, supra note 22, at 52-53; SKOGAN, Disorder ANd DeCline, supra note 9, at 73-75. 
spects, identical to Skogan's Figure 4-2.95 The replicated graph is reproduced below:

FIGURE 2:

Replication of Skogan's Figure 4-2

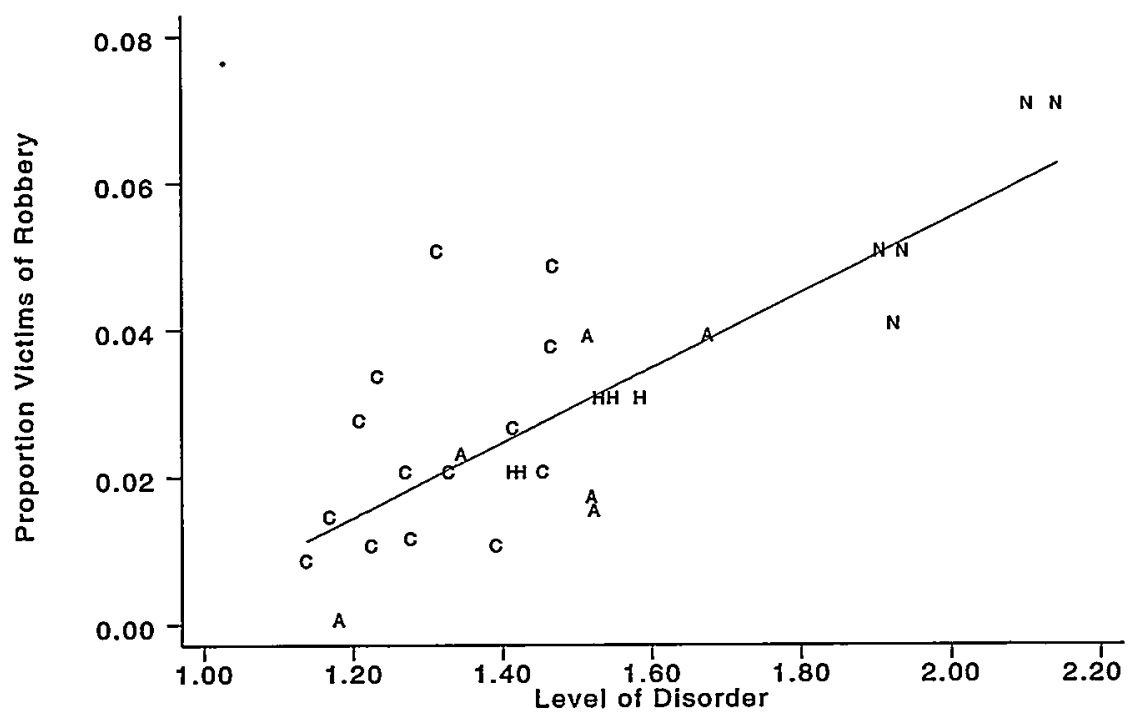

Given that the scatter-plots are identical, I am comfortable using my replication to estimate the coefficients and standard errors of Skogan's analysis. What the regression reveals is that, for every one unit increase in the level of disorder (where a unit is one of three unit measures of the level of disorder felt by the respondents (discussed below)), the proportion of victims of robbery in the neighborhood can be expected to increase by .05 (five percent) on average, with a standard error of plus or minus 0.007 . The ninetyfive percent confidence interval has, as a result, a small range, with a lower bound of 0.036 and an upper bound of 0.066 . The p-value (which is the probability of observing a t-statistic of 6.953, assuming that the null hypothesis is true) is extremely small in this case less than 0.001 - which means that it is extremely unlikely that

95. There are only two differences: first, I have labeled the y-axis "Proportion Victims of Robbery," rather than "Percent Victims of Robbery," as Skogan does on his Figure 4-2. "Proportion" seems more accurate since the robbery victimization variable in the data is measured by the proportion of respondents that answered "yes." ICPSR Codebook, supra note 74 , at 13 . Thus, in the data, the values of robbery victimization range from 0 to 0.07 (or 0 to $7 \%$ ) for the neighborhoods surveyed, not from 0 to 0.07 of $1 \%$ as Figure $4-2$ might suggest. Second, I use letters in the graph for abbreviations of the neighborhood locations by city (A for Atlanta, $\mathrm{C}$ for Chicago, $\mathrm{H}$ for Houston, and $\mathrm{N}$ for Newark). 
there is no statistical relationship. As a result, we can conclude from this that there is a near-zero probability that an estimate of .05 could have arisen by chance alone if there truly were no linear relationship between Skogan's variables for disorder and crime. ${ }^{96}$

\section{b. The Other-Explanatory-Variables Analysis}

Skogan's second analysis takes account of the level of poverty, stability and racial composition of the neighborhoods. In this case, Skogan did publish his coefficients and levels of significance, and I have been able to substantially reproduce them..$^{97}$ Skogan's and my results compare:

\section{Table 1: Replication of Skogan's Table A-4-1:}

\section{ROBBERY VICTIMIZATION}

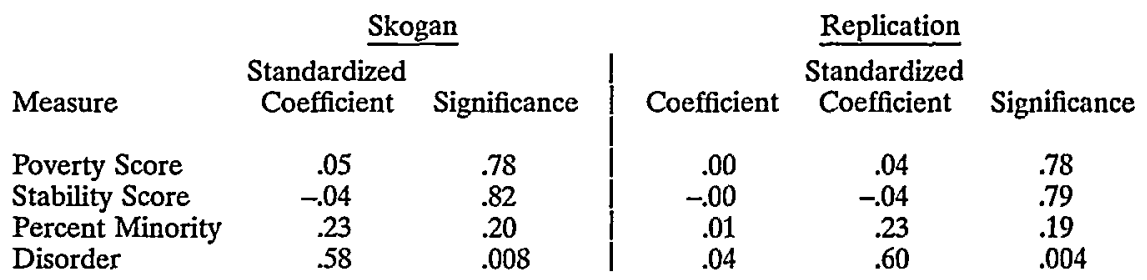

Skogan interprets his results as follows: "The correlation between residual values for robbery victimization and disorder, once the effects of poverty, stability, and racial composition had been removed statistically from each, was still high (+.54)."98 $\mathrm{He}$ concludes that "ignoring these demographic factors, there still was quite a strong tendency for crime and disorder to 'go together." 99

96. It is important to get a sense of these findings. All of the values for Skogan's index of neighborhood disorder were located between 1.20 and 2.20 on a 1 to 3 scale - where a score of 1 would have meant that respondents indicated that disorder was "no problem," a score of 2 would have meant that respondents indicated that disorder was "some problem," and a score of 3 would have meant that respondents indicated that disorder was "a big problem." See Skogan, Final Report, supra note 22, at 106; ICPSR Codebook, supra note 75, at 6 . In other words, the entire spectrum of observations of neighborhood disorder was located between something slightly more than "no problem" and something slightly more than "some problem" - a one unit increase in level of disorder. Therefore, what the analysis suggests is that, going from the lowest observed level of disorder in 30 neighborhoods all the way to the highest observed level of disorder in those 30 neighborhoods - neighborhoods which incidentally were chosen to refiect both disorderly and orderly neighborhoods, both high-crime and low-crime neighborhoods - the expected increase in the proportion of robbery victimization is on average five percent. See SKOGAN, Disorder AND DeCline, supra note 9, at 188 ("All of the areas were in the nation's largest cities. They were selected for a variety of reasons - among them, because they were high or low-crime areas, because programs were about to be started in them, and because they were stable or undergoing racial transition.").

97. See SKogAN, Disorder AND DeCLINE, supra note 9, at 193 tbl.A-4-1.

98. Id. at 73 .

99. Id. at 74; see also Skogan, Final Report, supra note 22, at 53. 
The replication confirms that Skogan's disorder index remains statistically significant when multiple regression is conducted with Skogan's indices for poverty, stability, and race. The replicated regression indicates that, holding those three other variables constant, for every one unit increase in the level of disorder, the proportion of victims of robbery in the neighborhood can be expected to increase by .038 on average ( 3.8 percent), with a standard error of plus or minus .012 . The ninety-five percent confidence interval has, as a result, a small range, with a lower bound of .014 and an upper bound of .062 .

\section{The Problems with the Data and Certain Design Decisions}

Nevertheless, certain problems with the data and some design decisions undermine my confidence in Skogan's findings and conclusions. I will begin with the issue of missing values.

\section{a. Missing Values}

A number of the underlying surveys are missing values for most of the important variables relating to the disorder-crime nexus. For instance, the Skogan and Maxfield study from $1981^{100}$ — which is the only study that covers neighborhoods in Philadelphia and San Francisco - does not have any values for the variables "noise," "litter," "trash," "gangs," "public drinking," and "insults," which are several of the main variables in Skogan's index of physical and social disorder. ${ }^{101}$ With a few rare exceptions, missing values actually plague all of the studies and all of the relevant variables to different degrees, as evidenced in the following table: 
Table 2: Missing Values in Skogan's Data Set

\begin{tabular}{lccccc} 
& \multicolumn{3}{c}{ PHYSICAL DISORDER } & & \\
& noise & abandon & litter & trash & total \\
number missing & 20 & 0 & 24 & 16 & 60 \\
percent missing & 50 & 0 & 60 & 40 & 37.5
\end{tabular}

SOCIAL Disorder

\begin{tabular}{lccccccc} 
& loitering & drugs & vandalism & gangs & $\begin{array}{c}\text { public } \\
\text { drinking }\end{array}$ & insults & total \\
number missing & 8 & 6 & 24 & 24 & 24 & 10 & 96 \\
percent missing & 20 & 15 & 60 & 60 & 60 & 25 & 40 \\
& \multicolumn{8}{c}{ CRIME VICTMIZATION } \\
& purse-snatching & assault & burglary & robbery & rape & total \\
number missing & 24 & 10 & 0 & 10 & 16 & 60 \\
percent missing & 60 & 25 & 0 & 25 & 40 & 30
\end{tabular}

As this table reflects, the data are missing values, on average, for between thirty and forty percent of the variables, which is a high percent given the small sample size (forty neighborhoods in all).

The more traditional way of dealing with this problem of missing values would be to disregard completely the neighborhoods that have missing values. But that is not possible with this data set. In the case of Skogan's indices of physical and social disorder, it is impossible because there is not one single neighborhood that has all the values for the relevant variables. As a result, Skogan does not disregard any neighborhood, but rather constructs his indices "by summing the component items which were available for each area and then dividing that sum by the number of available items."102 In other words, Skogan simply averages the values that are available. ${ }^{103}$ Aggregation, however, does not resolve the problem of missing values.

It is equally difficult to disregard the observations where crime victimization data are missing because it would leave us with only sixteen neighborhoods - only forty percent of our original small sample. This, however, is essentially what Skogan does with regard to victimization, using only the robbery victimization variable and therefore narrowing his study to just thirty available observations. ${ }^{104}$ The result is that, at least with regard to the disorder-crime

102. ICPSR Codebook, supra note 75, at 8 ; see also Skogan, Final Report, supra note 22, at 108.

103. This decision raises another problem discussed infra section II.A.3.b.

104. See Skogan, Disorder ANd Decline, supra note 9, at 73-75; Skogan, Final Report, supra note 22, at 50-53. 
nexus, Skogan's is a study of only thirty neighborhoods with many missing values of disorder.

\section{b. Selecting the Independent Variable}

The independent variable that Skogan employs is also problematic and may include, in my opinion, elements of the dependent variable. Skogan's independent variable is called "disorder" and it is constructed by averaging two multi-item scales, "social disorder" and "physical disorder."105 "Social disorder" and "physical disorder" are both constructed by averaging the values of a number of variables, each of which corresponds to respondents' answers (on a scale of one to three) to a question assessing the extent to which a certain type of disorder is perceived by them as a problem in their neighborhood. ${ }^{106}$ The variables included in the two multi-item scales are the following:

$\begin{array}{ll}\text { Social Disorder } & \text { Physical Disorder } \\ \text { Loitering } & \text { Noise } \\ \text { Drug Use \& Sale } & \text { Abandoned Buildings or Vehicles } \\ \text { Vandalism } & \text { Litter } \\ \text { Gang Activity } & \text { Trash in Vacant Lots } \\ \text { Public Drinking } & \\ \text { Insulting Language } & \end{array}$

So, for instance, in the case of the variable "litter," respondents would have been asked to assess the extent to which "garbage or litter on the streets and sidewalks" is a problem in the neighborhood. ${ }^{109}$ For all of these variables, the possible values range from 1 ("no problem"), to 2 ("some problem"), to 3 ("a big problem").110 The two multi-item scales were constructed "by summing the component items which were available for each area and then dividing that sum by the number of available items."111

Using respondents' assessment of drug trafficking or gang activity, however, presents a significant problem given that the depen-

105. See ICPSR Codebook, supra note 75 , at 7-8.

106. See id. at 6-8.

107. See id. at 7. Skogan's treatment of these variables is inconsistent. Compare Skogan, Final Report, supra note 22, at 16 (gangs and insults variables not listed as part of index) with id. at 107 (gangs and insults variables included in the index). I believe that the ICPSR Codebook and the Final Report at 107 are correct.

108. See ICPSR Codebook, supra note 75 , at 8.

109. See id. at 7.

110. See id. at 6.

111. Id. at 8. 
dent variable is supposed to be the level of serious criminal activity. In effect, the analysis may be slightly tautological, because some of these disorderly activities - like drug trafficking or certain gang activities - would be considered by respondents to be major crimes in themselves and are likely to trigger responses that assess the level of crime in the neighborhood. It is important to eliminate, as much as possible, the overlap between the independent and the dependent variable.

To be precise, the broken windows theory suggests that minor disorder, both physical (in the sense of litter and broken windows) and social (in the sense of minor misdemeanor offenses) is causally related to serious crime. Therefore, the independent variable (disorder) should not include - or should minimize as much as possible - serious criminal activity. Some degree of overlap is inevitable, given that the respondents may be thinking about criminal activity when they assess, for instance, the problem of abandoned buildings which today are a symbol of the crack house. It is crucial, however, to reduce the overlap as much as possible. Accordingly, it would probably be best to eliminate drug trafficking and gang activity from the independent variable.

A second problem with Skogan's independent variable results from missing values. Creating the index by simply averaging the existing values for the set of variables may produce bias. For instance, the mean for the variable "noise" is 1.3.112 The mean for the variable "public drinking" is 1.8.113 As a result, neighborhoods for which there is no value for "noise" may end up having higher values for the index "disorder" than they would otherwise, whereas neighborhoods for which there is no value for "public drinking" may end up having lower values for the "disorder" index than they would otherwise. This presents the possibility of potential bias and could be resolved by standardizing the variables on their means.

Thirdly, Skogan excluded from his indices of disorder four measures of disorder that were available from the data - these measures were the variables "smut" (adult movies and bookstores); "prostitution"; "dogs" ("barking loudly or relieving themselves near your home"); and "garbage" ("[p]eople not disposing of garbage properly or leaving litter around the area"). ${ }^{114}$ Skogan compiled these four variables under the heading "Measures of

112. See Skogan's Data, supra note 80.

113. See id.

114. See ICPSR Codebook, supra note 75, at 6-7. 
Disorder," but did not include them in his index for two reasons. First, with regard to the commercial sex variables, Skogan discovered that they were independent measures of disorder. Skogan writes:

At the individual level, reactions to these problems [prostitution and smut] formed a separate factor in every area in which they were included. A separate index of the extent of commercial sex problems was formed, but - as the status of the items as a separate factor hints - it was correlated only +.18 with the summary disorder measure and was not related to other neighborhood factors in the same fashion as either social or physical disorder. . . . As a result, this cluster of (very interesting) problems will not be considered in any detail in this report. ${ }^{115}$

Second, Skogan suggests that the questions were asked in too few cases. Neither of these reasons for excluding the commercial sex variables from the index of disorder is compelling. The fact that the commercial sex variables are independent of the other indices of disorder is not a reason to ignore those variables. The broken windows theory includes prostitution in its conception of disorder. In fact, the Broken Windows essay repeatedly refers to prostitutes and street prostitution - they are an integral part of the disorderly and of disorder. The fact that these very interesting - I would say, fascinating 116 - findings about commercial sex are at odds with the broken windows theory is not a reason to discard the variables, particularly when testing the theory's validity. Moreover, the "smut" and "prostitution" variables contain sixteen observations each, which is the same number as, for instance, "litter," "public drinking" or "vandalism." The "dogs" and "garbage" variables are only missing two more values. ${ }^{117}$ I therefore would not exclude those variables.

\section{c. Selecting the Dependent Variable}

Another reservation concerns the selection of the dependent variable. Skogan is interested in measuring the impact of disorder on crime and, throughout his book, he claims to be studying the rela-

115. Skogan, Final Report, supra note 22, at 19.

116. This is a fascinating finding. What Skogan found was that there is an independent commercial sex factor distinct from social and physical disorder: that these measures of disorder do not hang together. Using the data, I find that the correlation between prostitution and robbery victimization is -.10 ; and that there is no statistically significant relationship (pvalue of .712). Smut and robbery victimization are correlated at -.27 and the regression produces a p-value of .304 . This is a fascinating challenge to the broken windows theory and puts into serious question the essay's emphasis on prostitutes.

117. See Skogan's Data, supra note 80. 
tionship between disorder and crime. The passage in his book is, after all, entitled "Disorder, Crime, and Fear."118 The principal paragraph is captioned "Disorder and Common Crime."119 The repeated reference to the statistical findings are to the "crimedisorder connection" or the "relationship between disorder and crime."120 Another caption reads "Does Disorder Cause Crime?"121 It would appear from all this that Skogan's study relates to general crime levels. However, Skogan selects as the dependent variable only one crime, namely robbery - even though the data contain a number of other crimes, such as purse snatching, physical assault, burglary, and sexual assault. This is especially troubling because robbery victimization, it turns out, is one of the crime victimization variables with the highest relationship to neighborhood disorder, and, even more importantly, is the only crime victimization variable that remains statistically significantly related to disorder when neighborhood poverty, stability, and race are held constant.

With regard to the crime-disorder regression, robbery, burglary and physical assault have extremely low p-values, which suggests that they are statistically significantly related to disorder. Sexual assault has a very high p-value $(0.66)$, which signifies that in all likelihood it is not related to disorder; purse-snatching/pocket-picking appears to be only marginally related to disorder, but in an inverse relationship, suggesting that, if anything, it might be inversely related to disorder. This is demonstrated in the following table:

\section{Table 3: Coefficients for Skogan's Index of Disorder AND INDIVIDUAL CRIMES}

SKOGAN'S INDEX OF DISORDER

\begin{tabular}{|c|c|c|c|c|c|}
\hline \multirow{2}{*}{ CRIME } & \multirow[t]{2}{*}{ Coefficient } & \multirow[t]{2}{*}{ Standard Error } & \multirow[t]{2}{*}{$\underline{P \text {-value }}$} & \multicolumn{2}{|c|}{$95 \%$ Conf. Interval } \\
\hline & & & & & \\
\hline Purse snatching & -0.025 & 0.017 & 0.16 & -0.06 & 0.01 \\
\hline Physical Assault & 0.055 & 0.014 & 0.000 & 0.027 & 0.083 \\
\hline Burglaty & 0.076 & 0.025 & 0.004 & 0.026 & 0.126 \\
\hline Robbery & 0.051 & 0.007 & 0.000 & 0.036 & 0.066 \\
\hline Sexual Assault & 0.001 & 0.003 & 0.659 & -0.005 & 0.008 \\
\hline
\end{tabular}

What is even more troubling, however, is that the statistical relationships regarding physical assault and burglary vanish if neighborhood poverty, stability, and race are held constant. Robbery

118. See Skogan, Disorder ANd Decline, supra note 9, at 73 (emphasis added).

119. See id.

120. See id. at 73-74 (emphasis added).

121. See id. at 75. 
victimization is the only variable that remains related to disorder if we take socioeconomic factors into account. The coefficients are reproduced in the following table:

Table 4: Coefficients for Skogan's Index of Disorder ANd INDIVIdUAL CRIMES HOLdING CONSTANT NeIGHBORHOOD Poverty, StaBILITY, AND RACE

SKOGAN'S INDEX OF DISORDER

\begin{tabular}{|c|c|c|c|c|c|}
\hline & \multirow[t]{2}{*}{ Coefficient } & \multirow[t]{2}{*}{ Standard Error } & \multirow[t]{2}{*}{ P-value } & \multicolumn{2}{|c|}{$95 \%$ Conf. Interval } \\
\hline & & & & & \\
\hline aatching & -0.013 & 0.027 & 0.639 & -0.072 & 0.046 \\
\hline Physical Assault & 0.014 & 0.019 & 0.459 & -0.025 & 0.054 \\
\hline Burglary & -0.006 & 0.035 & 0.875 & -0.078 & 0.066 \\
\hline Robbery & 0.038 & 0.012 & 0.004 & 0.014 & 0.062 \\
\hline Sexual Assault & 0.006 & 0.006 & 0.341 & -0.007 & 0.019 \\
\hline
\end{tabular}

As this table demonstrates, it would be improper to conclude from the data that, as a statistical matter, general levels of crime or common crime - and disorder are related. Even setting aside all the problems with the data set, the data suggest that one particular crime, namely robbery, may be statistically related to disorder.

Skogan justifies using robbery victimization exclusively as an index of local levels of crime for the following reasons: "methodological research suggests it is reliably measured; it tends to correspond better than many other victimization measures with comparable official crime statistics; aggregate city-level studies indicate it is linked to fear of crime; and comparable measures of robbery victimization were included in 30 of the areas surveyed."122 On close scrutiny, however, these reasons are not entirely persuasive. The reasons, in part, touch on a hotly contested area in criminology and it is somewhat daunting, in this respect, to criticize Skogan given that he is a recognized expert in the area of victimization surveys. As Gove, Hughes, and Geerken suggest in their 1985 article, "[t]he person who has perhaps done the most work with the victimization surveys is Skogan."123 Nevertheless, there are reasons to be skeptical of the arguments.

First, robbery victimization is not the only measure that corresponds well with comparable official crime statistics. Burglary does

122. Skogan, Disorder and Decline, supra note 9, at $195 \mathrm{n} .1$ (Ch. 4) (internal citations omitted); Skogan, Final Report, supra note 22, at 52 n.7 (internal citations omitted).

123. Walter R. Gove et al., Are Uniform Crime Reports a Valid Indicator of the Index Crimes? An Affirmative Answer with Minor Qualifications, 23 CRTMINOLOGY 451, 468 (1985). 
too. 124 This is generally explained by the fact that the most powerful predictor of whether a crime is reported to the police appears to be the seriousness of the offense. ${ }^{125}$ Second, with regard to rape and physical assault, victimization surveys substantially underreport incidences among acquaintances, friends, and relatives, ${ }^{126}$ and they therefore measure very different things than the Uniform Crime Reports. ${ }^{127}$ But this does not address the cross-jurisdictional reliability of victimization surveys for rape or physical assault. The same biases might affect cross-jurisdictional comparisons of victimization surveys and of official crime statistics. ${ }^{128}$ In sum, the issue presented here is not the comparability of victimization surveys and official crime statistics, which is what Skogan discusses. The issue is the comparability of victimization surveys across neighborhoods. It is the cross-jurisdictional reliability of victimization surveys. ${ }^{129}$

Moreover, as a technical matter, there are no missing values for burglary victimization in the data, whereas there are ten missing values for robbery - and there are as many missing values for robbery as there are for physical assault. ${ }^{130}$ This would militate in favor of using burglary as the dependent variable. This is especially true given that it appears, from the Final Report and the Codebook, that the measure of robbery victimization is not neighborhoodspecific. Whereas the typical purse-snatching question ${ }^{131}$ and assault question ${ }^{132}$ specifically referred the interviewee to acts committed "in the neighborhood where you live now," and whereas the typical burglary question is by definition neighborhood specific, the

124. See id. at 479.

125. See id. at 468.

126. See id. at $464-65$.

127. See id. at 465.

128. See id. at 466.

129. Skogan's 1981 article, On Attitudes and Behaviors, does not address the crossjurisdictional reliability of victimization surveys either. See Wesley G. Skogan, On Attitudes and Behaviors, in ReActions to CRTME 19 (Dan A. Lewis ed., 1981).

130. See Skogan's Data, supra note 80.

131. "During the past year, in the neighborhood where you live now, has anyone picked your pocket or taken a bag or package directly from you without using force or threatening you?" ICPSR Codebook, supra note 75, at 13 (emphasis added); Skogan, Final Report, supra note 22 , at 115 (emphasis added).

132. "During the past year, in the neighborhood where you live now, has anyone physically attacked you or has anyone threatened or tried to hurt you even though they did not actually hurt you?" Skogan, Final Report, supra note 22, at 115; ICPSR Codebook, supra note 75 , at 13 . 
robbery question ${ }^{133}$ and the rape question ${ }^{134}$ apparently did not specify the location of the attack. In other words, it is possible that the robbery and rape questions could have been interpreted by the interviewee as referring to incidents that happened outside their neighborhood. This militates even more in favor of using the burglary variable.

Skogan's arguments do not fully address these concerns. ${ }^{135}$ In my opinion, if we are going to draw conclusions about the effect of disorder on common crime or general levels of crime, it may be more conservative to look at each substantive crime for which we have data and make a more nuanced assessment of the disordercrime relationship. ${ }^{136}$

\section{d. The Newark Effect}

As noted above, all of the statistically significant relationships between disorder and the individual substantive crimes vanish when neighborhood poverty, stability, and race are held constant, except robbery. The only reason robbery remains statistically significant, it turns out, is Newark. If you look at Skogan's Figure 4-2, you will notice that the five Newark neighborhoods, in contrast to the other city neighborhoods, are clustered together. ${ }^{137}$ If you put your hand over those five Newark observations and look only at the other twenty-five neighborhoods, the relationship between disorder and robbery victimization seems much less obvious. And, in fact, it is. Holding constant the same three explanatory variables (poverty, stability, and race), there is no significant relationship between disorder and robbery victimization when the five Newark neighborhoods are excluded. I call this the Newark Effect and it is summarized in the following table: ${ }^{138}$

133. "Since the first of this year, has anyone stolen something directly from you by force or after threatening you with harm? PLUS: Other than that, has anyone tried to take something from you by force even though they did not get it?" ICPSR Codebook, supra note 75, at 13; Skogan, Final Report, supra note 22, at 115.

134. "Has anyone sexually attacked you, or tried to, since the first of this year?" ICPSR Codebook, supra note 75, at 13; Skogan, Final Report, supra note 22, at 115.

135. See supra note 122 and accompanying text.

136. This is, incidentally, what Sampson and Cohen do. See infra note 146 and accompanying text. They look at both burglary and robbery and publish their findings about burglary, even though those findings do not support their position. See Robert Sampson \& Jacqueline Cohen, Deterrent Effects of the Police on Crime: A Replication and Theoretical Extension, 22 L. \& Socy. Rev. 163, 175-79 (1988).

137. See Skogan, Disorder ANd Decline, supra note 9, at 74 fig.4-2.

138. I am indebted to Mike Gottfredson for this insight. Gottfredson eye-balled Skogan's Figure 4-2 and immediately suggested to me that the correlation likely was almost entirely due to Newark. 
Table 5: The Newark EFfect: Coefficients for Skogan's INDEX OF DISORDER AND ROBBERY VICTIMIZATION EXCLUDING Newark NeIghborhoods and Holding Poverty, Stability, AND RACE CONSTANT

\begin{tabular}{lrccccc} 
& \multicolumn{3}{c}{ ROBBERY } \\
& Coef & SE & & P-val & & \multicolumn{2}{c}{ 95\% Conf. Interval } \\
EXPL. VARIABLES & & & & & & \\
Disorder & .011 & .025 & .670 & -.042 & .063 \\
Poverty & .001 & .003 & .741 & -.006 & .008 \\
Stability & -.002 & .003 & .517 & -.008 & .004 \\
Race & .014 & .008 & .109 & -.003 & .03
\end{tabular}

In fact, without the Newark neighborhoods, the relationship between robbery victimization and disorder vanishes if race alone is held constant:

TABle 6: The Newark EfFect: Coefficients for Skogan's INDEX OF DISORDER AND ROBBERY VICTIMIZATION EXCLUDING Newark NeIgHborhoods aND Holding ONLy Race Constant

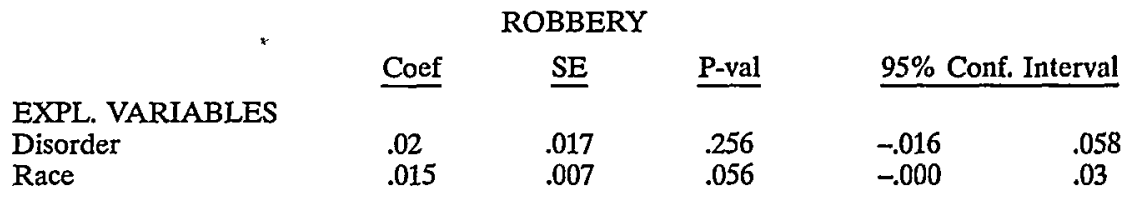

As Tables 5 and 6 demonstrate, the statistically significant relationship between disorder and robbery in the data is principally due to the five Newark neighborhoods that are all clustered together. In contrast, the other neighborhoods from the three other available cities (Atlanta, Chicago, and Houston) are pretty well distributed in the remaining group of observations. What this means is that, when all five Newark neighborhoods are included in a data set that contains only twenty-five other neighborhoods, Newark has a significant impact on the equation. Is it fair then to exclude the Newark neighborhoods, given that there are only thirty observations in all? I think so. Given the small number of observations, it is especially important to eliminate cases that exert too much influence on the findings. ${ }^{139}$ Newark seems to do just that. The point here is that it is not an individual neighborhood per se, but the Newark cluster

139. Skogan recognizes this and writes, in his methodological appendix, that "[t]he small size of the neighborhood and project-level samples examined here raises the spectre that a few cases exerted excessive influence on the statistical findings." SKOGAN, DisORDER AND DECLINE, supra note 9, at 191; Skogan, Final Report, supra note 22, at 117. Skogan ran a number of tests to defend against this problem, see Skogan, Final Report, supra note 22, at 
that excessively influences the results. What would it mean to have the relationship between disorder and robbery depend entirely on whether Newark is in or out of the data set? In my opinion, it suggests that the neighborhoods in Newark are skewing the results. ${ }^{140}$ Alternatively, it may suggest that there is a city effect, rather than a neighborhood effect, but that would stretch the theory too far. In the end, it is more conservative to exclude the Newark neighborhoods than it is to conclude from this data that disorder and crime are causally related. ${ }^{141}$

\section{Making the Best of the Data}

I will attempt here to redress some of the design decisions that I disagree with - at least those that can be corrected - in order to test the broken windows hypothesis. With regard first to the independent variable, disorder, I propose to create a new multi-item index of neighborhood disorder that incorporates only those variables that are not serious criminal activities (in other words that are not part of the dependent variable). I will therefore exclude the variables related to drug trafficking and gang activity. I will follow Skogan's lead and create a corrected index for social disorder and one for physical disorder and then average the two. ${ }^{142}$ I will refer to the new multi-item index as "corrected disorder." In addition, I will include the four other measures of disorder that were available from the data but that Skogan omitted from his indices - the first

117-18, but may have focused excessively on single observations tather than city-wide clusters like Newark.

140. The five Newark neighborhoods have the highest levels of disorder of the thirty observations. Excluding those five neighborhoods could be interpreted as selecting on the explanatory variable. That, however, should cause no inference problems. See GARY KING ET AL., Designing Social Inouiry 137 (1994) ("By limiting the range of our key causal variable, we may limit the generality of our conclusion or the certainty with which we can legitimately hold it, but we do not introduce bias."). Since the five neighborhoods do not have the highest levels of robbery victimization, their exclusion does not amount to selecting on the dependent variable, which in contrast would be problematic. See id. at 129.

141. I have one final reservation - though it is something that could be tested by going back to the data tapes. The study relies on self-reporting by the same people for the variables of disorder and crime victimization. In other words, the same people were asked to give their impression of the level of disorder in their neighborhood and to indicate whether they had been victimized by crime. The question I have is whether this might bias the study. After all, there is good reason to believe that persons who have been the victim of crime in their neighborhood are likely to perceive their neighborhood as disorderly. In fact, this is something that Skogan himself recognizes in another context. See Skogan, supra note 129, at 20-23. It is possible that the correlation Skogan identifies is due in some part to the fact that an individual's assessment of neighborhood disorder will be affected by that person's experience as a victim of crime - even though non-victimized respondents constituted more than $90 \%$ of the interviewees. Again, this is something that could be tested and controlled for.

142. I am following Skogan's lead and weighing equally physical and social disorder. See ICPSR Codebook, supra note 75, at 8; Skogan, Final Report, supra note 22, at 19. 
two ("smut" and "prostitution") in the social disorder index and the second two ("dogs" and "garbage") in the physical disorder index. The variables included in the two corrected multi-item scales thus consist of:

$\begin{array}{ll}\text { Social Disorder } & \text { Physical Disorder } \\ \text { Loitering } & \text { Noise } \\ \text { Vandalism } & \text { Abandoned Buildings or Vehicles } \\ \text { Public Drinking } & \text { Litter } \\ \text { Insulting Language } & \text { Trash in Vacant Lots } \\ \text { Smut } & \text { Dogs } \\ \text { Prostitution } & \text { Garbage }\end{array}$

With regard to the problem of missing values, I propose to standardize these twelve variables on their respective means. ${ }^{\mathbf{1 4 3}}$ This will avoid the problem of bias resulting from missing values (discussed supra). It is, of course, impossible to determine what the missing values would really have been. In this case, I am not entirely comfortable imputing values by means of multiple imputation because of the large number of missing values. I hesitate to possibly inject additional biases into this already weak data set.144 Standardizing the variables on their means is a more conservative approach.

In effect, what standardizing the variables does is to turn them into comparable measures of relative disorder. Let's take, for instance, two variables in the social disorder index, "public drinking" and "insults." At present, the values for each observation correspond to the respondents' perception of whether these are problems in the neighborhood on a scale of 1 to 3. The mean for the variable public drinking is 1.8 . The mean for the variable insults is 1.3. A neighborhood for which there is no data on public drinking, but data on insults, is likely to have a lower value for social disorder because of the missing data. However, by standardizing the two variables on their means, we create, instead of an absolute value for the variable, a relative weight of disorder. So, a neighborhood for which there is no data on public drinking will have a value for social disorder equal to the relative order or disorderliness of the neighborhood in terms of insults. Each variable will become a comparable relative indicator of the level of disorder. By averaging

143. In order to standardize the values for each variable, I will (1) calculate the mean of the variable; and (2) conduct the following calculation: standardized value $=($ value - mean $) /$ mean.

144. I surmise that Skogan may have felt the same way, which may explain why he did not impute values for the missing data. 
the available values, we will obtain a good indicator of the relative level of disorder in each neighborhood. In addition, the use of standardized values essentially substitutes for multiple imputation, insofar as it does similar work as the algorithms commonly used for imputation.

\section{The Corrected Results Using Skogan's Data}

a. The Corrected Disorder-Crime Regression Analysis

Looking only at "corrected disorder" and the various crimes, it appears that the corrected disorder variable continues to be statistically significantly related to three of the five crimes: physical assault, burglary, and robbery. At this preliminary stage, however, we can already conclude that purse-snatching/pocket-picking and rape are not significantly related to disorder. This is reflected in the following table:

\section{TABle 7: Regression Coefficients For CORRECTED Disorder AND INDIVIDUAL CRIMES} CORRECTED DISORDER

CRIME

Purse snatching

Physical Assault

Burglary

Robbery

Sexual Assault
Coef

-.05
.11
.14
.11
.001

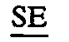

.03

.03

.05

.01

.007
P-val

.126

.001

.011

.000

.901
$95 \%$ Conf. Interval

$-.125$

.053

.033

.077

$-.013$
.017

.17

.24

.137

.015

\section{b. The Other-Explanatory-Variables Analysis}

With the single exception of robbery, however, these statistically significant relationships between individual crimes and disorder simply disappear when the socioeconomic factors are taken into account. 145

Physical Assault: using Skogan's indices for poverty, stability, and race, and holding these variables constant, neighborhood disorder is no longer statistically significantly related to the number of residents victimized by physical assault in their neighborhood. When we hold these three variables constant, a one unit increase in corrected disorder tends to increase physical assault by .007 on average, with a standard deviation of .04. The ninety-five percent confidence interval therefore has a lower bound of -.08 and an up-

145. With regard to purse-snatching, if stability alone is held constant, the p-value is 0.978 . 
per bound of .09 - suggesting that a good portion of estimated values will be inversely related to increases in disorder. The $\mathrm{p}$ value is very high, standing at .873 . This is reflected in the following table:

Table 8: Regression Coefficients for Physical Assault AND OTHER EXPLANATORY VARIABLES

Corrected Disorder PHYSICAL ASSAULT

Poverty

Stability

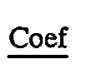

$\underline{\mathrm{SE}}$

P-val

$95 \%$ Conf. Interval

Race

$\begin{array}{rrrrr}.007 & .042 & .873 & -.08 & .09 \\ .013 & .005 & .014 & .003 & .022 \\ -.013 & .005 & .009 & -.024 & -.004 \\ -.002 & .013 & .856 & -.028 & .024\end{array}$

Burglary: the relationship between burglary victimization and corrected disorder also disappears when neighborhood poverty, stability, and race are taken into account. Holding these variables constant, neighborhood disorder is no longer significantly related to the number of residents victimized by burglary in their neighborhood. This is reflected in the following table:

TABLE 9: Regression CoEFFICIENTS FOR BURGLARY AND OTHER EXPLANATORY VARIABLES

Corrected Disorder

Poverty

Stability

Race

\begin{tabular}{|c|c|c|c|c|}
\hline \multirow[b]{2}{*}{ Coef } & \multicolumn{2}{|c|}{ BURGLARY } & & \\
\hline & SE & P-val & \multicolumn{2}{|c|}{$95 \%$ Conf. Interval } \\
\hline-.059 & .069 & .401 & -.2 & .081 \\
\hline .022 & .007 & .004 & .008 & .036 \\
\hline-.029 & .007 & .000 & -.043 & -.014 \\
\hline-.009 & .02 & .636 & -.05 & .031 \\
\hline
\end{tabular}

As a result, it is only robbery that remains significantly related to disorder holding constant Skogan's other explanatory variables. However, when we exclude the five Newark neighborhoods and hold constant the explanatory variables, even the robbery relationship vanishes. This is reflected in the following table: 


\section{Table 10: The Newark Effect: Coefficients for Robbery AND OTHER EXPLANATORY VARIABLES EXCLUDING NEWARK NEIGHBORHOODS}

EXPL. VARIABLES

Corrected Disorder

Poverty

Stability

Race

\begin{tabular}{|c|c|c|c|c|}
\hline \multirow[b]{2}{*}{$\mathrm{Cos}$} & \multicolumn{4}{|c|}{ ROBBERY } \\
\hline & SE & P-val & $95 \%$ & erval \\
\hline .06 & .04 & .141 & -.022 & .141 \\
\hline-.000 & .003 & .988 & -.006 & .006 \\
\hline .001 & .003 & .794 & -.006 & .008 \\
\hline .014 & .008 & .089 & -.002 & .03 \\
\hline
\end{tabular}

\section{Conclusion}

My findings using the corrected disorder index essentially track my earlier replication using Skogan's index for disorder. They suggest that, in the final analysis, there are no statistically significant relationships between disorder and purse-snatching, physical assault, burglary, or rape when other explanatory variables are held constant, and that the relationship between robbery and disorder also disappears when the five Newark neighborhoods are set aside. In the end, the data do not support the broken windows hypothesis.

\section{B. The Sampson and Cohen Study}

When pushed on the details of Skogan's analysis, social norm proponents cite one other quantitative study, Robert Sampson and Jacqueline Cohen's Deterrent Effects of the Police on Crime: A Replication and Theoretical Extension. ${ }^{146}$ This study, however, is by no means a silver bullet for the social influence conception of deterrence. To the contrary, the study takes a far more nuanced approach and, in the end, supports the argument that the social scientific evidence for the broken windows theory is still lacking.

Sampson and Cohen acknowledge that research on the relationship between disorder and crime is "sparse"147 and that the results thus far have been "mixed." 148 Their study focuses on two possible mechanisms - only one of which is the broken windows hypothesis - by which aggressive, proactive policing strategies might relate to lower crime rates. The first mechanism, which they refer to as "indirect," operates by increasing the arrest/offense ratio. ${ }^{149}$ Aggres-

146. Sampson \& Cohen, supra note 136. Tracey Meares brought this study to my attention; Dan Kahan also refers to the study in his work. See Kahan, Social Influence, supra note 12 , at $372 \& \mathrm{n} .82-83$.

147. See Sampson \& Cohen, supra note 136, at 167.

148. See id. at 166.

149. See id. at 164 . 
sive, proactive policing results in a greater number of police-civilian exchanges, during which the police are more likely to solve crimes. "By stopping, questioning, and otherwise closely observing citizens, especially suspicious ones, the police are more likely to find fugitives, detect contraband (such as stolen property or concealed weapons), and apprehend persons fleeing from the scene of a crime."150 Under the first hypothesis, aggressive policing affects crime "by changing the actual probability that an arrest is made (e.g., by increasing the arrest/offense ratio)."151 The second mechanism, which they refer to as "direct," operates by influencing community perceptions regarding the certainty of punishment. ${ }^{152}$ The heightened police presence and interventions that accompany proactive policing communicate to potential criminals that they are more likely to be caught if they commit a crime. This second mechanism is the one that is explicitly linked to the broken windows theory and the social influence conception of deterrence. The authors make this link by using, as the measure of aggressive policing, "the number of arrests per police officer for disorderly conduct and driving under the influence (DUI)."153

Sampson and Cohen report the following results. With regard to the indirect effect, proactive policing appears to have a significant effect on robbery and burglary arrest certainty rates. Robbery arrest certainty appears to have a significant inverse effect on the rate of robberies - second only to that, believe it or not, of the divorce rate. ${ }^{154}$ Burglary arrest certainty has only a marginally significant effect on burglary rates. With regard to the direct effect, proactive policing appears to have a very weak effect on burglary and, for that reason, the authors focus the remainder of their study on robbery, where there appears to be, in contrast, a significant inverse effect. ${ }^{155}$ With regard to robbery, "[t]he magnitude of the effect is clearly much less than that of divorce, but it is similar to that

150. Id. (quoting James Q. Wilson \& Barbara Boland, The Effect of the Police on Crime, 12 L. \& SocY. Rev., 367, 373 (1978)).

151. Id.

152. See id. at 165.

153. Id. at 169 (emphasis omitted).

154. See id. at 176. The authors do not explain why the divorce rate would have such an important effect, see id. at n.10, but it does, not only here, but also with regard to the next findings.

155. The authors acknowledge that other studies have found no relationship between indices of aggressive policing (number of traffic citations issued) and robbery rates, see id. at 167 (referring to Herbert Jacob \& Michael Rich, The Effects of the Police on Crime: A Second Look, 15 L. \& Socx. REv. 109, 113 (1981)), although Sampson and Cohen join Wilson and Boland in criticizing these findings. 
of region, income, and size."156 The direct effect also varies by age and race of the offender. "[P]olice aggressiveness has a much larger (inverse) effect on black adult robbery offending than on white adult robbery offending. . . . Similarly, the effect of police aggressiveness on white juvenile robbery is insignificant, while the corresponding effect for black juvenile robbery is significant and almost double in magnitude." 157

However, in the end, the authors acknowledge that their study does not establish whether aggressive policing affects the robbery rate by means of the direct or the indirect mechanism:

It is true, however, that our analysis was not able to choose definitively between the two alternative scenarios [indirect or direct] posed by Wilson and Boland (1978). One cannot determine empirically the direct effects of both police aggressiveness and the arrest/offense ratio on crime in a simultaneous equation model because such a model is unidentified. ${ }^{158}$

Sampson and Cohen favor the direct mechanism interpretation, in large part because of the sharp criticisms that have been leveled against the indirect deterrence literature. But, in the final analysis, the study is inconclusive.

\section{New York City's Falling Crime Rates}

Social norm proponents marshal still other evidence in support of the quality-of-life initiative. This consists of the remarkable fact that crime rates in New York City have plummeted in recent years - years that have coincided, in large part, with the implementation of the quality-of-life initiative. Kahan tallies the numbers as follows: "Since 1993, the murder rate [in New York City] has come down nearly 40 percent, the robbery rate more than 30 percent, and the burglary rate more than 25 percent."159 Former Police Commissioner William J. Bratton also emphasizes "the turnaround that has been accomplished in New York City. Crime is down by more than 50 percent from 1990. Murders are down by 63 percent." As a result, Bratton observes, "[t]here will be 200,000 fewer victims of ma-

156. Sampson \& Cohen, supra note 136, at 176.

157. Id. at 177 .

158. Id. at 185. The authors explain how a model can be unidentified by defining the alternative: "[t]he crime function in such a model is 'identified' when an instrumental variable is selected (e.g., police aggressiveness) that is both highly correlated with the sanction variable (e.g., arrest certainty) and at the same time does not have a direct effect on crime." Id. at $165 \mathrm{n}$.1. In their case study, the model is unidentified because the instrumental variable (police aggressiveness) apparently has a direct effect on crime. See id. at 175-76.

159. Kahan, Social Influence, supra note 12, at 367. 
jor crimes this year than there were in 1990."160 Moreover, the crime rates in New York City have fallen much more than in other large cities. Kahan emphasizes that "[t]hese drops are more than double the national average," 161 and, he argues, the only thing that can account for this difference is the quality-of-life initiative. Kahan reports, though citing only Bratton and Kelling, that "[c]ity officials and at least some criminologists credit the larger reduction in crime rates to [the] recent emphasis on 'order maintenance." 162

Here again, though, the devil is in the details. Criminologists have suggested a number of possible factors that may have contributed to the declining crime rates in New York City. These include a significant increase in the New York City police force, a general shift in drug use from crack cocaine to heroin, favorable economic conditions in the 1990s, new computerized tracking systems that speed up police response to crime, a dip in the number of eighteento twenty-four-year-old males, an increase in the number of hardcore offenders currently incarcerated in city jails and state prisons, the arrest of several big drug gangs in New York, as well as possible changes in adolescent behavior. ${ }^{163}$ Many of these factors are significant. None may single-handedly account for the trend. But each one must be taken seriously.

Kahan suggests, for instance, that "New York City has increased its investment in law enforcement over the course of a decade, but no more so than other cities around the country, none of which has

160. Bratton, supra note 8 . The statistics regarding the drop in the crime rate in New York City are from the FBI's Uniform Crime Reports and the FBI's numbers are compiled using local police data. See generally Gove et al., supra note 123. Police statistics are more susceptible to human manipulation than are victimization surveys. It is important to keep this in mind, particularly during periods of intensive policing initiatives. See, e.g., For One NYC Captain, Crime Reductions Are a Numbers Racket, Law ENFORCEMENT News (Dec. 15, 1996) <http://www.lib.jjay.cuny.edu/len/96/15dec/html/6.html (reporting that the commander of a high-crime precinct in the South Bronx is under investigation for falsifying reports to show huge reductions in crime); Fox Butterfield, As Crime Falls, Pressure Rises to Alter Data, N.Y. Times, Aug. 3, 1998, at A1 (reporting that, "[s]o far this year, there have been charges of falsely reporting crime statistics [in Philadelphia], in New York, Atlanta and Boca Raton, Fla."). Unfortunately, victimization survey data from the National Crime Victimization Survey are not available at the city level. Telephone Interview with Ann Pastore, Editor, Sourcebook of Criminal Justice Statistics, The Hindelang Criminal Justice Research Center, State Univ. of N.Y. at Albany (June 15, 1998).

161. Kahan, Social Influence, supra note 12, at 367-68.

162. Id. at 368-69.

163. See Fagan et al., supra note 11; Butterfield, supra note 11; Andrew Karmen, What's Driving New York's Crime Rate Down?, LAw ENFORCEMENT News (Nov. 30, 1996) <http:/l www.lib.jjay.cuny.edu/len/96/30nov/html/feature.html $>$. For discussions of the leading explanations of the national drop in crime rates, see generally Campbell, supra note 24, at 24; Alexis Chiu, Crime Rate at 29-year Low in City, Boston Globe, Aug. 28, 1997, at A1; Kaplan, supra note 45, at E1; Witkin, supra note 7, at 30-37. 
seen reductions in crime as dramatic as New York's."164 Kahan notes, in the margin, that "[i]n the decade ending in 1994, New York increased its spending on police by $74 \%$; the nation's nine largest cities excluding New York increased police spending by $70 \%$ on average."165 The difference between seventy-four and seventy percent may not, at first blush, seem very important. However, it has had a significant impact on the number of police officers per capita in New York City. A close inspection of the number of police officers per capita in the ten largest cities in the country reveals that, whereas New York City was among the top players in the previous decades, New York City has jumped in front of the pack in the mid-1990s. Throughout the 1960s, 1970s, and 1980s, New York City was elbow-to-elbow in a close cluster among the top-ranked largest cities in terms of its police force. This is illustrated in the following table: ${ }^{166}$

\section{Table 11: Police Officers Per 10,000 citizens IN tHe five LARGEST CITIES (RANKED BY ORDER)}

1960

1. Chicago (33)

2. New York (32)

3. Philadelphia (30)

4. Detroit (28)

5. Los Angeles (24)
1970

Chicago (47)
Philadelphia (44)
New York (44)
Detroit (37)
Los Angeles (32)

1980

1990

Philadelphia (49)
Chicago (45)
New York (38)
Detroit (38)
Los Angeles (31)

Detroit (50)

New York (50)

Chicago (49)

Philadelphia (48)

Dallas (36)

However, in the last few years for which data are available, New York City has led its peers. The sustained additional spending over many years, plus the accelerated investment in police officers since 1994, has had a significant impact on the numbers. This is reflected in the following table: 167

164. Kahan, Social Influence, supra note 12, at 368.

165. Id. at 368 n.68.

166. The number of police officers are derived from FedERAL BurEaU of INVESTIGAtion, U.S. Depr. of Justice, Uniform CRIMe Reports: Crime in the UnIted States ("UCR") for each respective year. See UCR-1960 (Table 36); UCR-1970 (Table 57); UCR-1980 (Table 71); and UCR-1990 (Table 72). The population numbers are derived from U.S. Census Bureau, Annual Time Series of Population Estimates, 1991 to 1996, and 1990 Census Population for Places (last revised August 20, 1998) <http://www.census.gov/ftp/ pub/population/www/estimates/cityplace.html $>$ [hereinafter Annual Time Series] for the population figure for 1990; and, respectively, the U.S. DEPT. OF COMMERCE, 1960 CENSUS OF Population, 1970 Census of Population and Housing, and 1980 Census of PopulaTION AND HOusing for the years 1960, 1970, and 1980.

167. See UCR-1993 (Table 78); UCR-1994 (Table 78); UCR-1995 (Table 78); and UCR-1996 (Table 78) for the number of police officers. See Annual Time Series, supra note 166, for the population estimates for 1993, 1994, 1995, and 1996. 
Table 12: Police Officers Per 10,000 citizens in the five LARGEST CITIES (RANKED BY ORDER)

1993

1. New York (54)

2. Chicago (51)

3. Philadelphia (45)

4. Detroit (43)

5. Houston (39)
1994

Chicago (55)
New York (54)
Philadelphia (46)
Detroit (44)
Houston (41)

1995

New York (66)

Chicago (57)

Philadelphia (49)

Detroit (43)

Houston (42)
1996

New York (66)

Chicago (58)

Philadelphia (50)

Detroit (45)

Houston (42)

Former Mayor Dinkins hired thousands of new police officers under the Safe Streets, Safe City program in 1992, and, since then, Mayor Giuliani has hired another four thousand officers and merged about six thousand Transit and Housing Authority officers into the ranks of the NYPD. ${ }^{168}$ The increased investment in law enforcement, it appears, has had a tangible effect on the number of police officers per capita.

Kahan also argues that "[s]imilarly, demographic shifts - including changes in the size of the teenage male population - are far too small to account for New York's drop in crime and are no different from those in other cities." 169 The raw numbers do indeed suggest that demographics may not account primarily for the drop in crime or for the difference in the rate of the drop in New York City. According to Jeffrey Fagan, Franklin Zimring, and June Kim, the highest at-risk population for homicides - non-white males ages fifteen to twenty-nine - has been declining since the mid1980s and the decline therefore does not correspond to the trend in overall homicides. ${ }^{170}$ "Accordingly," they write, "it is tempting to dismiss demography as a correlate of the homicide decline. However, the relationship of population to a changing behavioral pattern may be nonlinear."171 Researchers of youth violence and epidemiologists have suggested that long-term population declines may not affect rates of violence until certain thresholds or tipping points have been reached. The question that such a hypothesis would pose is "did the population decline reach a threshold where it could lead to a decline in the incidence of firearm homicides?"172

168. See Bratton, supra note 8.

169. Kahan, Social Influence, supra note 12, at 368.

170. See Fagan et al., supra note 11. When Fagan, Zimring, and Kim distinguish between firearm homicides and nonfirearm homicides, see infra text accompanying notes 191-97, they do find a strong relationship between the at-risk population decline (including white and black males) and the long-term decline in nonfirearm homicides. See Fagan et al., supra note 11.

171. Id.

172. Id. 
Further research would need to be conducted to answer this question. Fagan and Zimring suggest that this hypothesis is unfalsifiable and conclude, with regard to the demographic contribution, that "the contraction in the highest risk population is an important but unknowable influence on the decline in firearm homicides [in New York City] from 1992-1996."173 I am not entirely persuaded that the hypothesis is unverifiable and believe that further research needs to be conducted on this contributing factor.

There are other reasons too that may account for the sharp drop in crime in New York City. For instance, the substitution by drug users of heroin for crack cocaine may have contributed to the decline. One of the more authoritative studies on the relationship between crack cocaine and homicides in New York City found that, in the late 1980s, crack dealing significantly contributed to the homicide rate. ${ }^{174}$ In fact, twenty-six percent of the homicides in New York City in 1988 were estimated to have been crack-related systemic events - systemic to crack dealing. ${ }^{175}$ During an eightmonth period in 1988, 52.7 percent of homicides in New York City were projected to have been drug related, and, of those, sixty percent involved the use or trafficking of crack. ${ }^{176}$ In contrast, only three of the 414 homicides in the study were primarily related to the use or trafficking of heroin. ${ }^{177}$

The study suggested that the contribution of crack to the homicide rate was primarily through trade-related, or systemic, effects, including territorial disputes among crack dealers. ${ }^{178}$ Of the 118 homicides that were traced primarily to crack involvement, 100 (eighty-five percent) were attributed to the crack trade. ${ }^{179}$ Three of the crack-related homicides were attributed to the psychopharmacological consequences of ingesting crack, i.e. increased violence, excitability, and irrationality produced by crack; and eight homicides were attributed to economic compulsion, i.e. persons feeling compelled to engage in crime in order to subsidize drug use. The fact that the crack homicides were predominantly related to the crack trade, rather than to the psychopharmacologi-

173. Id.

174. See Paul J. Goldstein et al., Crack and Homicide in New York City, 1988: A Conceptually Based Event Analysis, 16 CONTEMP. DRUG PROBs. 651, 681-82 (1989).

175. See id. at 682 .

176. See id. at 681.

177. See id. at 683.

178. See id. at 656 (describing hazards of the drug trade).

179. See id. at 656, 664 tbl.2. 
cal consequences of using crack, however, does not minimize the contrast between crack-related and heroin-related homicides in New York City during that period: 118 to three. The stark contrast is illustrated well in the following table: ${ }^{180}$

\section{TABle 13: DRUg-Related Homidides IN Four Representative Patrol Zones in New York City (MARCH 1, 1988 - October 31, 1988)}

\begin{tabular}{|c|c|c|c|c|c|}
\hline & Number & $\begin{array}{l}\text { Psycho- } \\
\text { pharm. }\end{array}$ & $\begin{array}{c}\text { Economic } \\
\text { compulsive }\end{array}$ & Systemic & $\begin{array}{c}\text { Multi- } \\
\text { dimension }\end{array}$ \\
\hline Total number of homicides: & 414 & & & & \\
\hline Primarily Drug-related Homicides $\mathbf{1 8 1}$ & 218 & 31 & 8 & 162 & 17 \\
\hline \multicolumn{6}{|l|}{ Primary drug: } \\
\hline Crack & 118 & 3 & 8 & 100 & 7 \\
\hline Cocaine & 48 & 1 & 0 & 44 & 3 \\
\hline Alcohol & 21 & 21 & 0 & 0 & 0 \\
\hline Marijuana & 7 & 1 & 0 & 6 & 0 \\
\hline Heroin & 3 & 0 & $\mathbf{0}$ & 2 & 1 \\
\hline Combinations (non-heroin) & 18 & 5 & 0 & 7 & 6 \\
\hline Combinations (with heroin) & 0 & 0 & 0 & 0 & 0 \\
\hline Unknown & 3 & 0 & 0 & 3 & 0 \\
\hline
\end{tabular}

The important corollary is that cocaine use is down sharply in New York City, and some suggest that it is being substituted with heroin. Since the early 1990s, the consumption of cocaine in large cities, including New York, has been waning. ${ }^{182}$ In Manhattan, "the proportion [of youthful arrestees testing positive for cocaine] fell from 70 percent in 1987 to 21 percent in 1996."183 In addition, "a variety of studies also suggest that today's crack market is increasingly dominated by an older, mostly male group of heavy users."184 This may result in fewer homicides "because this age group is less prone to violence, and many of these users have long-term, stable relationships with their suppliers."185

180. See id. at 663-64 (Table 1 and 2).

181. This is a conservative estimate. Any case for which there was not sufficient evidence was classified "not drug-related" even if the police suggested that the case probably was drug related. See id. at 662 .

182. See Study by Andrew Golub and Bruce Johnson of the National Development and Research Institutes in New York (showing steep decrease in crack use among people being sent to jail in Manhattan), discussed in Fox Butterfield, Drop in Homicide Rate Linked to Crack's Decline, N.Y. TIMEs, Oct. 27, 1997, at A12 (documenting these trends in other cities); Witkin, supra note 7, at 36; see also generally Neal Kumar Katyal, Deterrence's Difficulty, 95 Mich. L. Rev. 2385, 2402-08 \& nn.63-65 (1997) (citing studies). But see Fagan et al., stupra note 11 (suggesting that the incidence of drug-positive arrestees has been stable and is unrelated to homicide trends).

183. Witkin, supra note 7, at 36; see also Butterfield, supra note 182, at A12 (discussing Golub \& Johnson, supra note 182).

184. Witkin, supra note 7 , at 36 .

185. Id. 
In contrast to New York City, mid-size cities - cities with populations of several hundred thousand, like Louisville, Kentucky, or Nashville, Tennessee - are now suffering from the effects of increased crack use and, as a result, are defying the national downward trend in crime rates. These smaller cities are apparently going through the urban crisis that hit the bigger cities in the 1980s and are experiencing a resulting crime wave. In Louisville, for instance, according to federal and local authorities, homicides in 1997 jumped to a seventeen-year high. ${ }^{186}$

Another important factor contributing to declining crime rates in New York City is the use of new computer technology to compile crime statistics and to convert the data into maps and charts that inform the police about crime patterns in different precincts. The data allow the police to target their enforcement to changing crime trends. A sergeant at the NYPD explains: "Let's say we're having a problem with Laundromat robberies in Brooklyn. I can pull from the $\mathrm{CD}$ all the listed Laundromats in Brooklyn, map them, shade in color the ones that are already robbed and see if we can spot a pattern. There's a lot of possibilities."187 According to experts like David Kennedy, senior researcher with the Program in Criminal Justice at Harvard's John F. Kennedy School of Government, these new technologies have contributed to the falling crime rates in New York City. ${ }^{188}$

The most thorough analysis to date on the relationship between New York City's policing initiative and serious crime is the forthcoming study by Jeffrey Fagan, Franklin Zimring, and June Kim entitled Declining Homicide in New York City: A Tale of Two Trends. ${ }^{189}$ In their study, the authors analyze a large number of potential explanations for the sharp, fifty-two percent drop in homicides in New York City during the five-year period 1992-1996. As a

186. See Michael Janofsky, Missing Trend, Some Cities See Murders Rise, N.Y. Times, Jan. 15,1998 , at A1; see also Witkin, supra note 7, at 36 ("Experts believe that the link between crack, guns, and crime can also be demonstrated in places where crime hasn't dropped smaller cities in the heartland where crack has only recently arrived.").

187. Tod Newcombe, Crime Drops 38 Percent in New York City, Government TechNOLOGY (Mar. 1997) <http://www.govtech.net/1997/gt/mar/march97-crimedropsinnyc/ march97-crimedropsinnyc.shtm $>$ (quoting Sgt. John Yohe, NYPD).

188. See id; see also Peter C. Dodenhoff, LEN salutes its 1996 People of the Year, the NYPD and its Compstat process, LAw ENFORCEMENT News (Dec. 31, 1996) <http://www.lib. jjay.cuny.edu/len/96/31dec/html/feature.html>; Eli Silverman, Mapping Change: How the New York City Police Department Re-engineered Itself to Drive Down Crime, LAw ENForCEMENT NEws (Dec. 15, 1996) <http://www.lib.jjay.cuny.edu/len/96/15dec/html/12.html> ("Perhaps the most significant aspect of the department's organizational changes within the past few years has been the process known as Compstat.").

189. Fagan et al., supra note 11. 
preliminary matter, the authors observe that New York's decline in homicides is the third highest decline for major cities in the United States, behind the decline in Pittsburgh and equal to that in Houston. ${ }^{190}$ The major finding of the study is that the trend in homicide rates has been different for firearm and nonfirearm homicides. Whereas firearm homicides first increased in the late 1980s and early 1990s and then declined sharply, nonfirearm homicides have steadily declined since $1987 .{ }^{191}$

The study suggests that the new policing initiative in New York City may not have affected the category of nonfirearm homicides. The authors indicate that the explanation for the long-term decline in nongun killings may lie elsewhere than in post-1990 interventions. ${ }^{192}$ It is worth emphasizing that nonfirearm homicides is not a trivial category of major crime. In 1995, there were 675 nongun killings, in contrast to 834 firearm homicides. ${ }^{193}$

With regard to firearm homicides, the study is less conclusive. The authors observe that "[t]he temporal fit between policing [strategy] changes and gun homicide declines is a good one."194 The authors suggest a number of factors that may also have contributed to the decline, including a certain amount of regression from peak rates in 1990, an increase in the police force, and social trends. The primary competing explanation for the sharp decline in gun killings is regression from abnormally high rates. ${ }^{195}$ Nevertheless, the authors write, "while the entire gun homicide drop of 1991 to 1996 is within the boundaries of regression possibility, the more prudent view is to regard the convergence of cyclical variation, social trends in risk and exposure, and law enforcement changes as jointly responsible" for the decline.196 Overall, the authors conclude on a cautionary note:

190. See id.

191. See id. ("What the gun trends obscure is the steadiest long-term trend in New York City - a downward movement in homicides by all means other than gun that begins after 1986 and gathers momentum steadily throughout the late 1980s and early 1990s.").

192. See id. ("Changes in policing were untelated to the long-term decline in non-gun homicides. This is a secular trend whose explanations lie beyond the hypotheses raised here about post-1990 interventions."); id. ("The consistent decline in nongun homicide . . . starts too early and continues too evenly throughout the period under study to have any plausible linkage to changes that come into the city two or three years into the 1990s."); $i d$. ("The nongun declines are in all probability not the consequence of policing changes or any other process that was not in effect until the 1990s.").

193. See id.

194. See id.

195. See id.

196. Id. A further complication, the authors point out, is that there have been many changes in policing, not just aggressive enforcement. Other changes include "gun interven- 
We have already learned that attributing nongun homicide declines to law enforcement changes was premature and unjustified. Rather than risk more precipitous error in the interpretation of the city's homicide trends, our current understanding of the period from 1985 to 1996 suggests caution. If the downward trend in gun killings continues far past the 1978 and 1985 levels, the probable role of the mid-1990s changes will loom larger with each further decline. If the nongun homicides also continue in their post-1986 pattern, however, even the best statistical views about New York homicide will not yield easy answers on causation. 197

In sum, there are a number of significant factors pushing down the crime rate in New York City. Criminologists, public policymakers and legal scholars are engaged in a hotly contested debate about the causes of the decline in New York City and nationally. 198 Some experts, including Dean James Alan Fox of the College of Criminal Justice at Northeastern University, argue that the crime rate in New York City would have dropped regardless of the quality-of-life initiative. ${ }^{199}$ Kahan may be right that no one force conventionally assumed to drive down crime rates in New York City is solely responsible for the drop in crime; however, the combined effect of numerous causal factors - like increased police, shifting drug use, new computerized tracking systems, demographics, and other factors - may account for the rate of the decline. Our present understanding of the causes of the decline is too tentative - and contested - to suggest that the quality-of-life initiative accounts for the difference in New York City's rates.

\section{An Alternative Mechanism of Order-Maintenance Policing: Enhanced Surveillance}

This is not to suggest that the quality-of-life initiative has had no effect whatsoever on crime rates in New York City, nor that it has had no deterrent effect whatsoever. The turnstile jumper who is going to commit greater offenses once he is in the subway is certainly

tions, general increases in police enforcement resources, strategic targeting of police efforts through computer mapping, and precinct-level management accountability for crime trends." Id.

197. Id.

198. See 88 J. CRIM. L. \& CRIMINology, supra note 11 (consisting of articles from conference focusing on declining crime rates); see also Witkin, supra note 7, at 28-33 (discussing the numerous proposed causes for the decline in crime nationally, and advocating the crack explanation). 40.

199. See Vince Beiser, Why the Big Apple Feels Safer, Maclean's, Sept. 11, 1995, at 39- 
deterred when he is arrested and detained.200 What is missing from the social influence explanation, however, is the brute fact that misdemeanor arrests in the city of New York have increased dramatically since Mayor Giuliani took office. As of 1996, misdemeanor arrests in New York City were up by more than fifty percent from 1993 levels: misdemeanor arrests in New York City reached 205,277 in 1996, up from 133,446 in 1993.201 The upward trend continued in 1997, with arrests for the first six months of 1997 standing at $117,698 .{ }^{202}$ In contrast, the number of misdemeanor complaints recorded for this period has remained remarkably stable - with 421,116 misdemeanor complaints recorded in 1993 compared to 424,169 in 1996.203

Misdemeanor arrests have increased, not only in number, but also in severity. The quality-of-life initiative has changed the procedures for those arrested. "Previously, most people accused of minor offenses were given desk appearance tickets, which included a court date, and then released."204 Under Mayor Giuliani's administration, desk appearance tickets became less common. The practice shifted to detaining, in jail, persons accused even of minor misdemeanor offenses for purposes of checking their identity and determining whether any outstanding warrants existed. ${ }^{205}$ Most recently, the New York City Police Department has implemented a new policy of detaining anyone arrested for even a minor misdemeanor offense "until a computerized fingerprint check verifies the person's identity."206 An apparently valid form of identification - like a driver's license - will no longer suffice: the police in New York City are now going to verify each person's identity by means of his or her fingerprints. This is "a process that takes up to eight hours in many cases." 207

200. See E.J. Dionne Jr., A Broken-Windows Approach to Crime, Wash. Post, Dec. 29, 1996, at C7.

201. See Letter from Michael J. Farrell to Jenna Karadbil, supra note 36; see also Purdy, supra note 11; Criminal Justice Indicators, New York City: 1992-1996 (last modified Dec. 10, 1997) <http://criminaljustice.state.ny.us/crimnet/ojsa/areastat/areastat.cgi>.

202. See Letter from Michael J. Farrell, Deputy Commissioner, City of New York Police Department to Author (Apr. 10, 1998) (on file with author).

203. See Letter from Michael J. Farrell to Jenna Karadbil, supra note 36.

204. Purdy, supra note 11; see also Cooper, supra note 11.

205. See Cooper, supra note 11; Purdy, supra note 11.

206. David Kocieniewski \& Michael Cooper, Police to Tighten the Scrutiny of All Suspects Under Arrest, N.Y. Times, May 28, 1998, at A1 ("Police Commissioner Howard Safir said yesterday that anyone arrested for even minor offenses, such as fare beating or drinking in public, must now remain in police custody until a computerized fingerprint check can verify the person's identity.").

207. Id. 
An alternative mechanism of order-maintenance policing then may be the enhanced power of surveillance offered by a policy of aggressive misdemeanor arrests and identification. What ordermaintenance policing gives law enforcement is a legitimate reason to seize, search, and run checks on persons committing or suspected of committing minor offenses, which may have important consequences for the detection and prevention of crime. This was powerfully demonstrated in the now-famous case of John Royster. Royster is accused of fatally beating a flower shop owner on Park Avenue - as well as several brutal assaults on women, including an infamous assault on a piano teacher in Central Park that left her severely impaired. Royster was fingered, literally, when he was arrested for turnstile jumping in the New York subways. Upon arrest, Royster was fingerprinted and a computer matched his prints with fingerprints left at the scene of the Park Avenue murder. ${ }^{208}$

The first quality-of-life experiment in the New York subways demonstrated early on the benefits of aggressive misdemeanor arrests. "As it turned out, many of those caught committing these small crimes were also guilty of larger crimes. One out of seven fare evaders had prior warrants out for their arrest. One out of 21 was carrying a handgun."209 With misdemeanor arrests up more than fifty percent in New York City and with routine fingerprinting and record checking, order-maintenance policing has "led to a 39 percent increase in arrests on outstanding warrants."210

Misdemeanor arrests may also be used as a way to take custody of a suspicious person where there may not otherwise be sufficient cause. This occurred recently when police officers arrested a suspicious person for jaywalking. Since he was not carrying identification, he was transported back to the police station, where he was put in a lineup and identified by two robbery victims. ${ }^{211}$

Order-maintenance policing also enhances surveillance by facilitating the transfer of information. Having patrol officers walk a beat makes it easier for citizens to pass information on to them.

208. See Purdy, supra note 11, at A1 (Royster "was identified by a fingerprint taken when he was arrested for jumping a subway turnstile.").

209. Kaplan, supra note 45 , at E1.

210. Purdy, supra note 11. Mayor Giuliani in fact recalls this well. "Very shortly into our program of dealing with squeegee operators - and I remember this - after the first group of arrests, Police Commissioner Bratton came back to me and said that some very large percentage - I don't remember the exact percentage - of the squeegee operators had warrants for other crimes, a number of them being violent crimes." See Onishi, supra note 11 (quoting Mayor Giuliani at a press conference on February 20,1998).

211. See Onishi, supra note 11. 
This is the sense in which, as Wilson and Kelling observed, "[t]he essence of the police role in maintaining order is to reinforce the informal control mechanisms of the community itself."212 Wilson and Kelling wrote:

Our experience is that most citizens like to talk to a police officer. Such exchanges give them a sense of importance, provide them with the basis for gossip, and allow them to explain to the authorities what is worrying them .... Y You approach a person on foot more easily, and talk to him more readily, than you do a person in a car. Moreover, you can more easily retain some anonymity if you draw an officer aside for a private chat. Suppose you want to pass on a tip about who is stealing handbags, or who offered to sell you a stolen TV. In the inner city, the culprit, in all likelihood, lives nearby. To walk up to a marked patrol car and lean in the window is to convey a visible signal that you are a "fink." 213

Order-maintenance policing not only facilitates communication, it may also create more potential informants by criminalizing more people.

In the final analysis, New York City's quality-of-life initiative has probably contributed to the decline in crime. But the mechanism may not be primarily a reduction in litter, fixing broken windows, or beautifying neighborhoods - though all of these may have some positive neighborhood effects. The primary engine of community policing in New York may be the enhanced power of surveillance offered by a policy of aggressive misdemeanor arrests. To be sure, this alternative hypothesis is also based, in large part, on anecdotal evidence, and it is essential that it too be operationalized and empirically verified. Like the broken windows theory, it is at present an untested hypothesis. But the empirical evidence does suggest that the quality-of-life initiative enables the police to collect more identifying information; that the policing strategy increases the opportunity for checking records, fingerprints, DNA, and other identifying characteristics; and that it also facilitates information gathering from informants. These mechanisms have little to do with fixing broken windows and much more to do with arresting window breakers - or persons who look like they might break windows, or who are strangers, or outsiders, or disorderly.

212. Wilson \& Kelling, supra note 2, at 34.

213. Id. at 34. 


\section{The Categories Underlying Order-Maintenance Policing}

The disorderly are, after all, the usual suspects under a regime of order-maintenance policing. The squeegee man, the panhandler, the homeless person, the turnstile jumper, the unattached adult, the public drunk - these are apparently the true culprits of serious crime. Wilson and Kelling refer to them as "disreputable or obstreperous or unpredictable people."214 They are the ones, Wilson and Kelling argue, who turn a stable neighborhood into "an inhospitable and frightening jungle."215 Skogan refers to them as "[u]nattached males, the homeless, and the aimless [who] live in boarded up buildings, seedy residential hotels and flophouses."216 Kahan rehearses the same categories. He writes:

Disorder is ... pregnant with meaning: Public drunkenness, prostitution, aggressive panhandling and similar behavior signal not only that members of the community are inclined to engage in disorderly conduct, but also that the community is unable or unwilling to enforce basic norms. ... In this environment, individuals who are otherwise inclined to engage in crime are much more likely to do so.

The meaning of disorder can also influence the behavior of committed law-abiders in a way that is likely to increase crime. If they can, law-abiding citizens are likely to leave a neighborhood that is pervaded by disorder. Their departure increases the concentration of law breakers, thereby multiplying their interactions with each other and accentuating their mutually reinforcing propensities to engage in crime. Law-abiders who stick it out, moreover, are more likely to avoid the streets, where their simple presence would otherwise be a deterrent to crime. ... The law-abiders' fear of crime thus facilitates even more crime. ${ }^{217}$

These categories divide the world into two distinct realms. But the line may not be so clear.

\section{A. Who Are the Disorderly?}

The Broken Windows essay betrays itself. Look closely at the essay. How do the police deal with the disorderly person? "In the words of one officer," the authors report, "We kick ass." "218 Or, as Wilson and Kelling explain elsewhere, the police "rough up" young

214. Id. at 30 .

215. Id. at 31-32.

216. Skogan, Final Report, supra note 22, at 86.

217. Kahan, Social Influence, supra note 12, at 370-71 (emphasis added, second emphasis in original).

218. Wilson \& Kelling, supra note 2, at 35. 
toughs, and arrest on suspicion. ${ }^{219}$ On close inspection, the desired order and regularity depend on irregularity and brutality.

"We kick ass.' Project residents both know and approve of this," the essay contends. "None of this is easily reconciled with any conception of due process or fair treatment,"220 the authors concede. It is, however, vital to the order-maintenance function. That function, after all, harkens back to the 1950s, when police officers assisted neighborhoods in asserting control over delinquency "sometimes violently."221 It looks back to a time when "[y]oung toughs were roughed up, people were arrested 'on suspicion' or for vagrancy, and prostitutes and petty thieves were routed. 'Rights' were something enjoyed by decent folk, and perhaps also by the serious professional criminal, who avoided violence and could afford a lawyer."222

The order-maintenance strategy also depends on arresting people on meaningless charges. What makes the system work is the availability of broad criminal laws that allow the police to take someone off the streets because they look suspicious. "Until quite recently in many states, and even today in some places, the police make arrests on such charges as 'suspicious person' or 'vagrancy' or 'public drunkenness' - charges with scarcely any legal meaning," Wilson and Kelling write. "These charges exist not because society wants judges to punish vagrants or drunks but because it wants an officer to have the legal tools to remove undesirable persons from a neighborhood when informal efforts to preserve order in the streets have failed." 223 In these situations, the desire for order excuses the questionable legality of the arrests. Returning to police officer Kelly on the Newark beat, the authors state: "Sometimes what Kelly did could be described as 'enforcing the law,' but just as often it involved taking informal or extralegal steps .... Some of the things he did probably would not withstand a legal challenge."224 These are, after all, euphemisms for the word "illegal."

The essay refers to many rules, especially the "informal but widely understood rules" of police-civilian encounters. ${ }^{225}$ The text seems to privilege regularity, but, in fact, it is irregularity that un-

219. See id. at 33.

220. Id. at 35 .

221. Id. at 33.

222. Id.

223. Id. at 35 .

224. Id. at 31.

225. Id. at 30. 
dergirds the analysis, because it is precisely the application of universal rules that most clearly undermines the order-maintenance function. The rigidity of rules, even rules that may be perfectly appropriate in individual cases, deprives police officers of needed flexibility. " $[\mathrm{N}] \mathrm{o}$ universal standards are available to settle arguments over disorder," 226 the essay contends. This explains why "a judge may not be any wiser or more effective than a police officer" in resolving street disputes.227 In fact, the text goes on to say, "[a] particular rule that seems to make sense in the individual case makes no sense when it is made a universal rule and applied to all cases." 228

In effect, regularity on the street rests on irregularity in police practice - mixed, of course, with the regularity of the persons targeted. The need for irregularity, in turn, triggers a demand for police discretion and expertise. Instead of burdening the police with rules of engagement, the article relies on training and selection. " $[\mathrm{H}]$ ow do we ensure that age or skin color or national origin or harmless mannerisms will not also become the basis for distinguishing the undesirable from the desirable?" the essay asks. ${ }^{229}$ The response: "We can offer no wholly satisfactory answer to this important question. We are not confident that there is a satisfactory answer, except to hope that by their selection, training, and supervision, the police will be inculcated with a clear sense of the outer limit of their discretionary authority."230

Brutality and irregularity are inscribed in the Broken Windows essay. They are linked to order, rules, and regularity. And, ironically, they operate at cross-purposes. For if, as the essay suggests, there is such a clear line separating order from disorder, then why do the police need so much discretion? Wouldn't disorder be immediately apparent to anyone? To a review board? To a court?

Order-maintenance policing embraces an aesthetic of order, cleanliness, and sobriety. But it also embraces irregularity, illegality, and brutality. Perhaps this is no accident. To borrow a phrase from Wilson and Kelling, "disorder and crime are usually inextricably linked, in a kind of developmental sequence."231 The authors were referring, of course, to disorder in the streets, not disorder in

226. Id. at 35.

227. $I d$.

228. Id.

229. Id.

230. Id.

231. Id. at 31. 
the police station house; yet the disorder that the authors seek to repress may return to haunt them.

Ultimately, order-maintenance policing rests on categories that are misleading. After all, who are the disorderly? Speeding is a crime. So is avoiding sales tax by paying cash, underestimating taxes, paying a housekeeper under the table, or taking office supplies home. The category of the disorderly is unstable. It triggers an aggressive response to the disorderly - reflected in the idea of "cracking down" on disorderly people - despite a lack of empirical evidence. ${ }^{232}$

At the same time, the categories self-deconstruct. This is illustrated well, in both Kahan's and Wilson and Kelling's articles, by their discussion of a particular social science experiment conducted in 1969 by Philip Zimbardo, a Stanford University psychologist. Both Kahan and Wilson and Kelling rely heavily on this study. Zimbardo arranged to have an abandoned automobile placed in a public space to see whether it would be vandalized. Zimbardo conducted the study twice, placing the automobile once on the campus of Stanford University and once in the Bronx in New York City. In the Bronx, the car was promptly vandalized. At Stanford, the abandoned car remained intact for a week. After a week, Zimbardo smashed the windshield, whereupon passers-by then began vandalizing the car.

Yet the vandals in Zimbardo's study did not fit the bill of "disorderly persons." Wilson and Kelling describe the Bronx suspects as follows:

The car in the Bronx was attacked by "vandals" within ten minutes of its "abandonment." The first to arrive were a family - father, mother, and young son - who removed the radiator and battery. Within twenty-four hours, virtually everything of value had been removed. Then random destruction began - windows were smashed, parts torn off, upholstery ripped. Children began to use the car as a playground. Most of the adult "vandals" were well-dressed, apparently clean-cut whites. ${ }^{233}$

These vandals do not seem to fall in the category of the "disreputable or obstreperous or unpredictable people."234 They do not seem to be drunks, addicts, rowdy teenagers, or unattached adults. Dan

232. See Kahan, Social Influence, supra note 12, at 351 ("Cracking down on aggressive panhandling, prostitution, open gang activity and other visible signs of disorder may be justifiable on this ground, since disorderly behavior and the law's response to it are cues about the community's attitude toward more serious forms of criminal wrongdoing.").

233. Wilson \& Kelling, supra note 2, at 31.

234. $I d$. at 30 . 
Kahan describes the vandals as "clean-cut passersby, many of whom gratuitously inflicted damage upon [the car]."235 Similarly, Wilson and Kelling describe the experiment at Stanford University: "The car in Palo Alto sat untouched for more than a week. Then Zimbardo smashed part of it with a sledgehammer. Soon, passersby were joining in. Within a few hours, the car had been turned upside down and utterly destroyed. Again, the 'vandals' appeared to be primarily respectable whites." 236 Kahan writes:

Zimbardo placed the car, hood up, on the campus of Stanford University, where it remained in pristine condition for over a week. Zimbardo then smashed the windshield with a sledgehammer. At that point, passersby spontaneously joined in the carnage, gleefully visiting further destruction upon the car and (over time) stripping it of valuable parts. The sight of others openly pillaging the car, Zimbardo concluded, had released passersby from their inhibitions against vandalism and theft. ${ }^{237}$

In what category do we place these "vandals"? Wilson and Kelling characterize them as "people out for fun or plunder," and even "people who ordinarily would not dream of doing such things and who probably consider themselves law-abiding."238 Are they "individuals who are inclined to commit crime"? Or are they respectable "law-abiders"? The point is, of course, that these may be the wrong questions. The proper question may be, why have these categories in the first place?

\section{B. Tracing the Problem Back to Social Theory}

It is somewhat jarring to uncover what appears to be a straightforward policy of aggressive misdemeanor arrests masquerading as a neighborhood beautification program or as an innocent phenomenon of social influence. It is especially jarring given, first, that social norm proponents want to find alternatives to the traditional devices of arrest and incarceration, and second, that the social science evidence does not support the policy. Where did we go off track?

The difficulty, in my opinion, traces back to these categories of honest persons and the disorderly, of order and disorder. These categories were borrowed from a traditional sociological approach developed in the work of Emile Durkheim. It is there, I would sug-

235. Kahan, Social Influence, supra note 12, at 356 n.27.

236. Wilson \& Kelling, supra note 2, at 31.

237. Kahan, Social Influence, supra note 12, at 356.

238. Wilson \& Kelling, supra note 2, at 31. 
gest, that we need to return in order to work our way out of the difficulty. I applaud the social influence conception of deterrence for enriching the discussion of public policy with sociology; however, what is still missing is a more theorized discussion of the sociology. Public policy and sociology need to be supplemented by an inquiry into social and political theory.

\section{Emile Durkheim on Legitimation and Legal Regulation}

The categories along the new path of deterrence resemble certain categories in the work of Emile Durkheim. Durkheim's discussion of criminal sanctions, especially his legitimation theory, rests on a similar distinction between honest and disorderly persons. Durkheim's discussion of anomie and, more generally, of the role of law in society, also reflects a similar privileging of order over disorder. These similarities are not entirely coincidental. The social norm scholarship in fact claims Durkheim as an intellectual predecessor, especially in relation to punishment and social construction. 239

Durkheim's theory of legitimation receives its most lucid treatment in his early work, On the Division of Labor in Society. ${ }^{240}$ Durkheim explores there the issue of social solidarity - that is, the issue of the moral cohesiveness of society. He argues that repressive criminal sanctions play a declining role in the production of social solidarity in modernity. In their place, legal regulations in the private law context - restitutionary principles in contract, property, and commercial law - increase in modern times and eventually offer the prospect of a healthy, in fact more robust, social solidarity.

Although criminal sanctions contribute less to the formation of social cohesion in modern times than in earlier periods, it is nevertheless the moral dimension of punishment that remains central to Durkheim's analysis. It is, in fact, this moral dimension of social cohesion that Durkheim identifies as the function of criminal punishment. According to Durkheim, criminal sanctions in modern society play the role of legitimating social norms and reinforcing solidarity within the community. Writing against the tradition of

239. Dan Kahan's discussion of the expressive dimension of punishment and his argument for shaming penalties explicitly trace back to the work of Emile Durkheim. See Kahan, supra note 18, at 594-96. See also Lessig, supra note 16, at $949 \mathrm{n} .19$ (placing Durkheim at the start of the tradition of constructivism that underlies social meaning).

240. Emile Durkheim, The Division of LABor IN Society (W.D. Halls trans., Free Press 1984) (1893). 
utilitarian theories of punishment, Durkheim argues that criminal punishments play a very small role in deterring crimes and an equally minimal role in rehabilitating offenders. It is, instead, legitimation of society that criminal sanctions achieve. ${ }^{241}$

Despite the fact that Durkheim was writing against the tradition of punishment theory that gives rise in part to the social influence conception of deterrence, Durkheim's work shares certain categories with social norm proponents. Underlying Durkheim's theory of legitimation are honest persons, the disorderly, and criminals. This is reflected most poignantly in the now-famous passage on legitimation from the Division of Labor:

[The role of punishment] is not the one commonly perceived. It does not serve, or serves only very incidentally, to correct the guilty person or to scare off any possible imitators. From this dual viewpoint its effectiveness may rightly be questioned; in any case it is mediocre. Its real function is to maintain inviolate the cohesion of society by sustaining the common consciousness in all its vigour. If that consciousness were thwarted so categorically, it would necessarily lose some of its power, were an emotional reaction from the community not forthcoming to make good that loss. Thus there would result a relaxation in the bonds of social solidarity.... This is why it is right to maintain that the criminal should suffer in proportion to his crime, and why theories that deny to punishment any expiatory character appear, in the minds of many, to subvert the social order. . . . Thus, without being paradoxical, we may state that punishment is above all intended to have its effect upon honest people. Since it serves to heal the wounds inflicted upon the collective sentiments, it can only fulfil this role where such sentiments exist, and in so far as they are active. ${ }^{242}$

The characters are all here: the honest person, the disorderly, the imitator. They play an integral role in Durkheim's analysis. For Durkheim - as well as for social norm proponents - the criminal sanction exerts social influence on the honest person and on the disorderly in different ways. Honest persons bond, develop richer social solidarity, a thicker social fabric. Criminal imitators, the disorderly, are deterred and sent on their way. These are the very characters that reappear along the new path of deterrence and these are their pathways.

There is also a striking parallel between Durkheim's emphasis on legal regulation and the new path's emphasis on order. For

241. For an extensive and comprehensive review of Durkheim's writings on punishment, see David Garland, Puntshment and Modern Society 23-46 (1990); David Garland, Durkheim's Theory of Punishment: A Critique, in THE POwer TO PUnsh (David Garland \& Peter Young eds., 1983); Steven Lukes \& Andrew Scull, Introduction to DuRKHEIM ON THE LAw 1-27 (Steven Lukes \& Andrew Scull eds.,1983).

242. Durkheim, supra note 240 , at $62-63$ (emphasis added). 
Durkheim, the social cohesion of modern society is at its optimal level when there is proper and sufficient legal regulation of commercial transactions on the basis of restitutionary principles. In contrast to societies that achieve healthy social solidarity by means of legal regulation, societies that become pathological suffer either from insufficient legal regulation - a state of anomie - or from the wrong kind of legal regulation - a state of forced division of labor. The categories of healthy social solidarity versus pathological anomic conditions bear a sharp resemblance to the privileging of order over disorder in the social influence conception of deterrence. This interpretation of Durkheim emphasizes substance over method, ${ }^{243}$ and his earlier work over his later work. ${ }^{244}$

At the substantive level, law, regularity, and order reign in Durkheim's enterprise. Not just any law, but an "iron law . . . against which it would be absurd to revolt."245 The primacy of legal regulation is clearly reflected in Durkheim's diagnosis of the pathological condition which he calls "the anomic division of labor." Anomie - from the Greek anomia, without law ${ }^{246}$ - represents for

243. In sharp contrast to Durkheim's substantive argument discussed in the body of this Article, Durkheim's method treats law as an evidentiary fact that is entirely derivative of the social phenomenon of the division of labor. At the methodological level, law is merely an effect, a consequence of social phenomena. This is the core of Durkheim's methodological insight: to use positive law as the measure with which to evaluate his dual hypotheses that (a) the function of the division of labor is to produce social solidarity, and (b) that the organic solidarity produced by the division of labor in modern societies is more robust than the mechanical solidarity produced by collective consciousness in ancient societies. Durkheim states this explicitly in the first chapter of the Division of Labor, which is dedicated to method. See Durkreim, supra note 240, at 24 . He there refers to positive law as an "external" datum which "symbolizes" the phenomenon of social solidarity. Law is the "perceptible effects" of social solidarity. It is "nothing more than this very organisation [the organisation of social life] in its most stable and precise form." Id. at 24-25. To use Durkheim's words, law symbolizes, reproduces, mirrors, corresponds, and provides an external interpretation of the moral phenomenon of social solidarity. See id. at 24-25, 27-28. Thus, at the methodological level, law is portrayed as a pure consequence: the collective consciousness and similarities of "lower" societies produce repressive laws and a mechanical form of solidarity, whereas the division of labor in modern society produces restitutionary laws and a more robust, organic solidarity. Law has no real autonomy and is not a force for change. And so Durkheim's principal texts on punishment - On the Division of Labor in Society and his article in L'Année Sociologique (1899-1900) entitled Deux lois de l'évolution pénale - recite a story about the declining role of repressive law in modern society. This is in sharp contrast to Durkheim's substantive argument about the modern regulation of society through private law principals.

244. Durkheim's later works, in particular his work on Moral Education, can be interpreted as placing greater emphasis on repressive sanctions - and expressive punishment as necessary for social solidarity. See Emile Durkhem: A Study in the Theory AND Application of the Sociology of Education (Everett K. Wilson ed., Free Press 1961) (1925); John Bratthwatte, Crime, Shame and Reintegration 178 (1989); Thomas J. Scheff, Review Essay: A New Durkheim, 96 AM. J. Soc. 741, 743 (1990).

245. DURKHEM, supra note 240 , at 122.

246. See Webster's Third New International Dictionary of the English Lan. GUAGE UNABRIDGED 89 (1986). 
Durkheim the primary pathology of modern society. It may take the form of the complete lack of regulation resulting in economic crises and bankruptcies. Or, it may take the form of inappropriate regulation, as in the case of the forced division of labor and the resulting class war. But in all events, it is the lack of regulation that "does not allow the functions to perform regularly and harmoniously."247

Under normal circumstances, human exchange produces "a body of rules":248 "[T]he division of labour gives rise to rules ensuring peaceful and regular co-operation between the functions that have been divided up."249 The lack of such rules - anomie - is pathological, and arises only in "exceptional and abnormal circumstances."250 Thus, for Durkheim, the division of labor takes on a heavily regulated nature. His is an idea of social organization based on the paradigm of rulemaking and obedience - what we might call today the rule of law.251

Durkheim posits a hierarchy between modern society and more primitive societies.252 Throughout his work, Durkheim disparages premodern societies, even borrowing from the discipline of phrenology to support his speculations about the greater homogeneity of early peoples.253 According to Durkheim, non-pathological modern societies demonstrate not only more robust social solidar-

247. DURKHEIM, supra note 240 , at 303.

248. Id. at 304 .

249. Id. at 338 .

250. Id. at 307 .

251. This was foreshadowed by Durkheim's use of metaphor. At the level of metaphor, law reigns in Durkheim's enterprise. Throughout the Division of Labor, Durkheim refers to social phenomena using metaphors of laws and duties. Durkheim describes the increase of organic solidarity in modernity as structural, necessary and universal. He writes, "this phenomenon is linked not to some accidental cause ... but to what is most vital in the structure of our societies .... So the law we established in the preceding chapter proves doubly useful to us. Besides confirming the principles on which our conclusion is based, it enables us to establish its universality." Id. at 102 (emphasis added). From the first page of his introduction onward, Durkheim characterizes the division of labor as a "law," as "the higher law of human societies," a "law of nature," and as necessary. Id. at 1,3 .

Law plays an equally important metaphoric role in Durkheim's essay - as evidenced by the very title - Deux lois de l'évolution pénale. The project of that essay is precisely to establish and explain certain "laws" about law - "deux lois qui nous paraissent dominer l'évolution du système répressif." See Emile Durkheim, Deux lois de l'évolution pénale, in L'ANNÉ SOCIOLOGIQUe 1899-1900, at 65 (1901). These two "laws" are (a) that the intensity of punishment increases in lower societies, as well as in authoritarian societies; and (b) that deprivation of liberty alone is tending to become the normal type of punishment. See id. at $65,78$.

252. See Durkheim, supra note 240 , at 92 . He calls the latter "les sociétés tout à fait inférieures." Emile DuRkheim, De La Division du Travail Soctal 108 (4th ed., Quadrige 1996) (1893).

253. See DURKHeIm, supra note 240 , at $89-92$. 
ity, but also greater individualism. Individual personality "develops with the division of labour," 254 which is one of the reasons that specialization becomes a moral duty. This hierarchy of modern over ancient societies reflects Durkheim's preference for legality and regulation. With regard to the enforcement of morals, for Durkheim, cooperation trumps coercion.

There is, consequently, a strong similarity between Durkheim and the social influence conception of deterrence - beyond merely the shared categories of honest persons and disorderly. Durkheim privileges regulation and minimizes repressive sanctions. Similarly, the new path of deterrence presents itself as an "alternative[] to the severe punishments that dominate contemporary criminal law."2s5 Rather than punish severely to deter, the new path seeks to enforce, in part, order or rules of civilian conduct that are geared to producing a more harmonious social environment with stronger moral bonds. In sum, the new path similarly endorses a form of social solidarity based on ordered relations.

\section{The Problem of Subject Creation}

The problem with Durkheim's distinction between honest and disorderly persons is that it fails to take into account that the categories themselves may be the product of the very processes that are supposedly being legitimated and that are legitimating society. The practices of punishment may participate in creating the categories of law abider and disorderly. But if, in fact, the processes of punishment not only create social solidarity among honest people, but simultaneously create the very category of honest people, then the legitimating effect on society is undermined. The same is true of the social solidarity produced by extensive legal regulation. Under Durkheim's theory, ordered legal regulations serve and uphold the natural division of labor, which in turn produces social solidarity. But what if the legal regulations, instead of merely upholding the social division of labor, actually divide society into the different social strata and create the division of labor that marks modern society? Certainly the division of labor would be less "organic," to use Durkheim's terminology. It would be less natural and healthy, and would instead resemble far more the "mechanical," imposed social solidarity achieved by pre-modern systems of repressive criminal sanctions.

255. Kahan, New Path, supra note 12, at 2478. 
Similar questions arise in the context of social influence theory. Under the social influence conception of deterrence, ordermaintenance policing influences the behavior of individuals who are inclined to engage in crime and of committed law abiders. It reduces law abiders' fear of crime and thereby induces them to engage in conduct that discourages crime - like walking the streets at night. At the same time, it dissuades the disorderly from engaging in crime by communicating that offenses will be punished. But what if order-maintenance policing, instead of merely influencing these categories of individuals, actually helps shape or create these categories? What if the order itself - the order privileged by order-maintenance policing - not only upholds the community norms that result in greater moral cohesion and lower crime rates, but instead creates those community norms? What if the order imposes norms on the community?

These challenges to Durkheim's hypotheses and, similarly, to the social influence conception of deterrence, have surfaced on a number of different occasions, in different guises, during the course of the late nineteenth and twentieth centuries. They are most often associated with the enfants terribles of their epoch. Friedrich Nietzsche, Jean-Paul Sartre, and Michel Foucault challenged, in different ways, the causal reasoning underlying Durkheim's sociology. They excavated and exposed, underneath the commonly accepted framework of causal explanations, other histories and processes.

Nietzsche attacked, among other things, the ideal of progress embodied in Christian morality, vociferously arguing that, rather than ennobling modern man, Christian morality had enfeebled man to a condition of vile servitude. Were God not dead, Nietzsche would have had him cry out to modern men: "O you dolts, you presumptuous, pitying dolts, what have you done! Was that work for your hands? How have you bungled and botched my beautiful stone! What presumption!"256 Nietzsche evoked here the plasticity of human nature - the way in which human nature is shaped like a work of art or, alternatively, a work of adultery. Nietzsche's genealogical enterprise aimed precisely at tracing the mechanisms, conflicts, and deceptions that produced the formidable changes in human nature from the original, forgetful, robust animal to the calculable, regular, and promise-keeping individual of modernity. ${ }^{257}$

256. Friedrich NIETzSCHE, Beyond GoOd ANd Evil 75 (Walter Kaufmann trans., Vintage Books 1966) (1886).

257. See Friedrich Nietzsche, ON the Genealogy of Morals 58-60 (Walter Kaufmann trans., Vintage Books 1967) (1887). 
Nietzsche did not accept the commonplace categories of virtuous and disorderly. Instead, he challenged the value of those categories, and attempted to unearth how processes, like punishment or sociability, shaped the modern soul. ${ }^{258}$ Sartre also exposed the brute and nauseous plasticity of the subject, perhaps nowhere better than in his first novel, La Nausée. ${ }^{259}$ For Sartre, there could be no fixed categories of disorderly and law abider, since human beings have the radical ability to redefine themselves at any moment in time. 260 In their different ways, Nietzsche and Sartre opened a space for an alternative vision of the human subject, in each case a vision that emphasized the malleability of the human subject and pointed to different forces that shaped the subject. ${ }^{261}$

\section{Michel Foucault and Subject Creation}

In relation to Durkheim, though, it is Michel Foucault's work that presents the most direct challenge. Foucault wrote Discipline and Punish against Durkheim's sociology. ${ }^{262}$ In the very first pages

258. On punishment, see, e.g., id. at 61 and 82 (punishment as a mnemotechnic device; and as hindering the feeling of guilt); on sociability, see, e.g., id. at 84-85 (socialization disvalued the instincts and turned man against himself, creating the modern soul).

259. JeAN-PAUl SARTRe, La NAusée 178-81 (1938).

260. See generally Jean-Paul SARTRe, L'eXISTENTLALISME EST UN hUManisme 58 (1958) ("Ce que nous voulons dire, c'est qu'un homme n'est rien d'autre qu'une serie d'entreprises, qu'il est la somme, l'organisation, l'ensemble des relations qui constituent ces entreprises.").

261. This is not to suggest that they were the first to offer such challenges. Others preceded them. They were foreshadowed, for instance, in the eighteenth century, by thinkers like Jean-Jacques Rousseau. Contrary to popular opinion, Rousseau argued passionately, the flowering of the arts and sciences in eighteenth-century Europe had eviscerated man's natural virtue. See Jean-Jacques Rousseau, The First Discourse, in The FIrst and SECOND DisCourses 36-38 (Roger D. Masters \& Judith R. Masters trans., Roger D. Masters ed., 1964). By exposing man's natural goodness, Rousseau offered an alternative vision of unalloyed freedom through participation and assent in the general will. See Jean-Jacques Rousseau, $O_{n}$ the Social Contract, in ON THE Social ConTRACT 52-54 (Judith R. Masters trans., Roger D. Masters ed., 1978). Rousseau's vision was, to be sure, marred by prescriptions for an authoritarian civil religion and, perhaps to a lesser extent, for an all-knowing legislator. See $i d$. at 124-32 (on Civil Religion); id. at 67-70 (on the Legislator). However, Rousseau thereby initiated a genealogical project that exposed the historical stages of human nature and revealed the ways in which society could transform the subject - though Rousseau ultimately held on to a fixed notion of genuine human nature corresponding to man in his natural state.

262. I think that the extent to which Foucault's work on punishment is a reaction against Durkheim's is underestimated in the secondary literature. Even David Garland, who provides a thorough and comprehensive review of Foucault's theory of punishment in Punish. ment and Modern Society does not, I believe, give adequate emphasis to this interpretation of Foucault. See, e.g., GARLAND, supra note 241, at 132 ("Foucault's analysis of punishment is quite distinct from Durkheim's, appearing to contradict it at a number of points, and, for the most part, dealing with phenomena which hardly appear in Durkheim's work."). The result is that the conventional readings of Foucault overestimate the place of power in the analysis and focus on social construction rather than subject creation. I believe that even Garland, to a certain extent, overemphasizes the theme of power in his discussion of Foucault and underemphasizes subject creation. See id. at 134-36. By focusing on the critical relationship be- 
of his genealogy of the prison, Foucault defines his project in opposition to Durkheim's. It is really only Durkheim he criticizes:

This book is intended as a correlative history of the modern soul and of a new power to judge. ...

But from what point can such a history of the modern soul on trial be written? . . By studying only the general social forms, as Durkheim did (cf. Bibliography), one runs the risk of positing as the principle of greater leniency in punishment processes of individualization that are rather one of the effects of the new tactics of power, among which are to be included the new penal mechanisms. ${ }^{263}$

Foucault appropriates Durkheim's celebrated concepts the better to distance himself from Durkheim's method. Foucault's reference point is Durkheim; and so, immediately following the preceding passage, Foucault writes (I will italicize the words that refer to Durkheim's thought):

This study obeys four general rules:

1. Do not concentrate the study of the punitive mechanisms on their 'repressive' effects alone, on their 'punishment' aspects alone, but situate them in a whole series of their possible positive effects, even if these seem marginal at first sight. As a consequence, regard punishment as a complex social function.

2. Analyze punitive methods not simply as consequences of legislation or as indicators of social structures, but as techniques possessing their own specificity in the more general field of other ways of exercising power. Regard punishment as a political tactic.

3. ... [M]ake the technology of power the very principle both of the humanization of the penal system and of the knowledge of man.

4. Try to discover whether this entry of the soul on to the scene of penal justice, and with it the insertion in legal practice of a whole corpus of 'scientific' knowledge, is not the effect of a transformation of the way in which the body itself is invested by power relations. ${ }^{264}$

As this passage makes clear, Foucault sets out to reinterpret the emergence of what Durkheim called "la personalité individuelle,"265 and which Durkheim attributed to the increasing social division of labor, by exploring the modern reconfiguration of the human body, the birth of the soul ("l'ame"), and the correlative

tween Foucault and Durkheim, this Article highlights Foucault's concern with subject creation.

263. Foucault, Discipline and Punish, supra note 34 , at 23 (emphasis added) (translation of Foucault, Surveiller ET PUNIR, at 27-28). In contrast, Foucault affiliates himself somewhat with the Frankfurt School, especially Rusche and Kirchheimer's Punishment and Social Structures (1939), see Foucault, Discrmline ANd Punish, supra note 34, at 24, and with the work of Gilles Deleuze and Felix Guattari.

264. Foucault, Discipline and Punish, supra note 34, at 23-24 (translation of Foucault, Surveiller Et PUnir, supra note 34 , at 28).

265. DURKHEIM, supra note 252 at 399. 
changes in the way that we judge others. Whereas Durkheim treats punishment as evidence of the function of other social phenomena, like the social division of labor, Foucault instead sets out to explore discipline as the object itself of a Durkheimian functional analysis. By explicitly citing only Durkheim and by appropriating Durkheim's concepts, like the "repressive" and the "social function," Foucault readily acknowledges Durkheim's preeminent place in the tradition. But when Foucault prescribes, as the first tenet of his method, "regard punishment as a complex social function," Foucault is essentially claiming to turn Durkheim's enterprise on its head. ${ }^{266}$ The principal deficiency of Durkheim's work, according to Foucault, is the failure to take account of the enabling effects of punishment on the subject. This critique may apply with equal force to the social influence conception of deterrence.

\section{A. Foucault on the Categories}

Foucault's genealogy of the prison addresses both strands of Durkheim's analysis. With regard first to the categories, Foucault's discussion of the role of the delinquent in the modern carceral society illuminates, by analogy, the role of the disorderly in the social influence conception of deterrence. The delinquent and the disorderly have much in common and it is, for this reason, crucial to rehearse Foucault's analysis. But the categories are also different in important ways. Whereas delinquency correlates with treatment, psychotherapy, and correction, the category of the disorderly is more closely associated with a militaristic method of rectification. The broken windows theory by no means advocates the more rehabilitative or psychotherapeutic remedies that characterize certain of the institutions described in Discipline and Punish. The broken windows theory borrows instead from the classical method of deterrence through excessive punishment, as well as the drill sergeant model of discipline.

266. Recall that Durkheim was very careful to differentiate the concept of function from that of effects or results and that he set out to investigate the function of the division of labor. See DurkheIm, supra note 240, at 11. He writes:

We cannot use "aim" or "purpose", and speak of the goal of the division of labour, because that would suppose that the division of labour exists for the sake of restults that we shall determine. To use "results" or "effects" cannot satisfy us either, because no idea of correspondence is evoked. On the other hand, the term "role" or "function" has the great advantage of implying that idea, but in no way prejudges the question of knowing how that correspondence has been established, or whether it arises from some intended and preconceived adaptation or from some adjustment after the event.

Id. Durkheim realizes his project - to investigate the function of the division of labor - by treating law (and punishment) within the category of effects. Foucault flips this by treating, as his principal object of study, the function of punishment. 
For this reason, the category of the disorderly offers an opportunity to refine Foucault's diagnosis of the modern carceral society. Insofar as we are living today - inescapably, at present - within a paradigm of the penitentiary, the differences between the delinquent and the disorderly open a window into the different subtypes of possible disciplinary practices. The social influence theory attempts to normalize the offender along the axis of order and disorder. However, if there is no evidence to support this axis of normalization, then it might be better to reform along a different axis, such as, for instance, poverty or stability. By refining Foucault's analysis, we may be able to draw its policy implications.

Foucault's description of the modern carceral society draws on a number of different mechanisms of disciplinary practice - for instance, discipline in the hospital, army, workplace, school, court, or home - and his discussion benefits from grouping these strategies together and highlighting their kinship. However, the consolidation may detract from a more nuanced discussion of the different modalities of discipline that characterize modern penalty - the differences precisely between discipline in the hospital and discipline in the workshop. By selecting from those different approaches within the larger rubric of discipline, we can begin to differentiate between ways of disciplining, between techniques of punishment. This may allow us to evaluate the quality-of-life initiative.

First, however, let me turn to the details of Foucault's analysis. In Discipline and Punish, Foucault explores three very different ways in which punishment has created the subject - how punishment has fundamentally altered the subject's self-understanding, habits, emotions, and desires. The three different modalities correspond to three different stages in the history of punishment: first, the brutal, torturous corporal punishments of the seventeenth and early eighteenth centuries; second, the representational and theatrical aspirations of the eighteenth century reformers; and third, the disciplinary mechanisms of spatial, temporal, and bodily control that capture the modern carceral system. Foucault suggests that these three modalities are not entirely distinct. Certain techniques from earlier historical periods are incorporated into later modalities. ${ }^{267}$ Foucault also suggests that the three mechanisms share important features. They each operate on the body of the convicted: the body is the intermediary between society and the subject.268 They each relate, idiosyncratically, to truth formation: they each

267. See infra note 283 (discussing Mettray).

268. Foucault writes: 
help constitute the truth. "The truth-power relation," Foucault suggests, "remains at the heart of all mechanisms of punishment."269 And they each seek to induce obedience among subjects 270 - but through very different operations on the body.

The severe, brutal techniques of dismembering, quartering, or branding convicts that characterize the seventeenth and early eighteenth centuries - what Foucault refers to as "les supplices" - inscribed the sovereign's power on the body of the condemned. The mark of punishment on the body of the convict served to confirm the truth of the crime and to rectify sovereign power. ${ }^{271}$ It signified to the people that the convicted subject, who was often led by torture to confession, had committed the crime, and it expressed the consequence of that crime. ${ }^{272}$ It also served to reconstitute the sovereign's power. The dissymmetry between the criminal act and the torturous punishment reflected the gross imbalance of power between the subject and the sovereign, and served as a spectacle of that very imbalance and excess. Punishment functioned as an example that demonstrated both the crime's existence, but also the sovereign's ability to master it. 273 In terms of prevention, it operated through terror.

In contrast, the eighteenth century reformers dreamt of another modality of punishment - one that, ultimately, would not be realized except through its faint reflections in the modern carceral system. Drawing first on themes of the eighteenth-century Enlightenment period - themes of equality, humanity, lenience, autonomy, and universality - and, second, on utilitarian principles of prevention and correction, the reformers imagined a system of coded penalties that would speak directly to the general public.

[1] $\mathrm{n}$ our societies, the systems of punishment are to be situated in a certain "political economy" of the body: even if they do not make use of violent or bloody punishment, even when they use "lenient" methods involving confinement or correction, it is always the body that is at issue - the body and its forces, their utility and their docility, their distribution and their submission.

Foucault, Disctiline and Punish, supra note 34, at 25 (translation of Foucault, SURVEILler ET PUNIR, supra note 34, at 30).

269. Id. at 55 (translation of Foucault, Surveiller ET Punir, supra note 34, at 59). 132).

270. See id. at 129 (translation of Foucault, SuRVeIller ET PunIR, supra note 34, at

271. See id. at 47 (translation of Foucault, Surveiller et Punir, supra note 34, at 50).

272. See id. at 43 (translation of Foucault, SURveIrler et PUNIR, supra note 34, at 47) ("It was the task of the guilty man to bear openly his condemnation and the truth of the crime that he had committed. His body, displayed, exhibited in procession, tortured, served as the public support of a procedure that had hitherto remained in the shade; in him, on him, the sentence had to be legible for all."). 96).

273. See id. at 93 (translation of Foucault, Surveiller et Punir, supra note 34, at 95 - 
Punishment was to be effectuated through countless different symbolic or "picturesque"274 sanctions scattered throughout all walks of life. Each penalty was to represent to the observer, in a more muted way than the classical model, the lesson to be learned. The idea was that of a "punitive city":

At the crossroads, in the gardens, at the side of roads being repaired or bridges built, in workshops open to all, in the depths of mines that may be visited, will be hundreds of tiny theatres of punishment. ... It will be a visible punishment, a punishment that tells all, that explains, justifies itself, convicts: placards, different-coloured caps bearing inscriptions, posters, symbols, texts read or printed, tirelessly repeat the code. ${ }^{275}$

This humanized spectacle was to serve, primarily, as a constant morality play, intended to teach a lesson to schoolchildren and adults about the consequences of vice. ${ }^{276}$ By reaching into all facets of everyday life, the reformist ideal sought to extend the reach of the example of punishment throughout the social body in a more egalitarian, regular, effective, constant, yet economic manner.277 Their project depended on publicity as a way to deeply reinforce the immediate association of crime and punishment - to "reactivat [e] the signifying system of the code."278

The modern carceral system operates by training the body with an arsenal of coercive techniques. These techniques include the strict control of time and space; the ranking of individuals and activities; the forced repetition of exercises; the examination and its accompanying comparisons, measures, hierarchies, and classifications; and the forced internalization of control through panoptic mecha-

274. Id. at 114 (translation of Foucault, Survemler Et Punir, supra note 34, at 116).

275. Id. at 113 (translation of FoUCAULT, SURVEILIER ET PUNIR, supra note 34, at 115). Foucault's description of the reformers' dreams bears some resemblance to the contemporary efforts to introduce shaming penalties into the law. It would be a fascinating project to explore the eighteenth-century debates concerning representational punishment in light of the contemporary debate over the use of emotions in criminal law. See James Q. Whitman, What Is Wrong with Inflicting Shame Sanctions?, 107 Yale L.J. 1055 (1998); Toni M. Massaro, The Meanings of Shame: Implications for Legal Reform, 3 Psychol. PUB. PoLY. \& L. 645 (1997); Dan M. Kahan \& Martha C. Nussbaum, Two Conceptions of Emotion in Criminal Law, 96 Colum. L. REv. 269 (1996); Kahan, supra note 18; Toni M. Massaro, Shame, Culture, and American Criminal Law, 89 Mich. L. Rev. 1880 (1991).

276. See Foucault, Discipline and Punish, supra note 34, at 113 (translation of Foucault, SURVeILler Et PUNIR, supra note 34, at 115) ("[T]he essential point, in all these real or magnified severities, is that they should all, according to a strict economy, teach a lesson: that each punishment should be a fable.... Around each of these moral 'representations,' schoolchildren will gather with their masters and adults will learn what lessons to teach their offspring.").

277. See id. at 80 (translation of Foucault, Surveiller et Punir, supra note 34, at 83).

278. Id. at 128 (translation of Foucault, Surveiller et Punir, supra note 34, at 131). 
nisms of surveillance. ${ }^{279}$ Unlike the reformers' emphasis on signs, the modality of modern punishment focuses on exercises like "timetables, compulsory movements, regular activities, solitary meditation, work in common, silence, application, respect, good habits."280 These exercises alter the subject's behaviors and habits, but also operate on the subject's desires and self-understanding. They correspond to the emergence of the subject as an object of knowledge. ${ }^{281}$ It is here, in the words of Foucault, "in these 'ignoble' archives" that can be found "the birth of the sciences of man."282

Discipline is a multi-faceted phenomenon composed of several different subsidiary clusters of techniques, corresponding to at least six primary social structures: the family, the school, the military, the workshop, the hospital, and the court. ${ }^{283}$ The modern carceral techniques are premised on the idea that subjects need to be trained in order to be improved; subjects need to be "normalized" - to be made more like the norm that society aspires to - rather than selected, with pre-existing habits and behaviors, from a fixed pool of individualities. ${ }^{284}$ By improving the subject, the techniques

279. See id. at 141-67, 167 (translation of FouCAult, SURVEILLER ET PUNIR, supra note 34, at 143-69, 169) ("[Discipline] operates four great techniques: it draws up tables; it prescribes movements; it imposes exercises; lastly, in order to obtain the combination of forces, it arranges 'tactics." "). 32).

280. Id. at 128 (translation of Foucault, Surveiller ET Punir, supra note 34, at 131 -

281. See, e.g., id. at 251 (translation of Foucault, Surveiller Et Punir, supra note 34, at 255) ("[T] he offender becomes an individual to know. This demand for knowledge was not, in the first instance, inserted into the legislation itself, in order to provide substance for the sentence and to determine the true degree of guilt. It is as a convict, as a point of application for punitive mechanisms, that the offender is constituted himself as the object of possible knowledge.").

282. Id. at 191 (translation of Foucault, SuRveIller ET PUNIR, supra note 34, at 193).

283. Foucault illustrates this point by means of a detailed discussion of Mettray, a juvenile center opened in $\mathbf{1 8 4 0}$ that housed not only juvenile delinquents, but also juveniles acquitted for mental health reasons and boarders. Mettray was a combination of prison, mental institution, and boarding school - what Foucault called "the carceral archipelago," $i d$. at 297 , or, elsewhere, "the first training college in pure discipline," id. at 295. Foucault characterizes Mettray as the crowning moment of the carceral system: "[T] he date of completion of the carceral system." Id. at 293. "Why Mettray?" Foucault asks. "Because it is the disciplinary form at its most extreme, the model in which are concentrated all the coercive technologies of behavior." Id. Mettray combined several disciplinary clusters, replicating the authority of the big brother, the inspections of the military superior, the supervision of the factory foreman, the examination of the school instructor, and the punishment meted out by the judge. The authorities at Mettray combined all these features: "They were in a sense technicians of behavior: engineers of conduct, orthopaedists of individuality." Id. at 294. Mettray is the picture perfect illustration of the carceral system. It is important to note, for our purposes here, that the juridical model formed a part of the disciplinary model - that it was incorporated as one element of the larger carceral system and not entirely discarded. See id. 172).

284. See id. at 170 (translation of Foucault, Surveiller ET Punir, supra note 34, at 
serve not only the negative function of preventing crime, but also the positive function of increasing utility and social wealth. This is the "functional inversion of the disciplines": "At first, they were expected to neutralize dangers, to fix useless or disturbed populations, to avoid the inconveniences of over-large assemblies; now they were being asked to play a positive role, for they were becoming able to do so, to increase the possible utility of individuals."285 These techniques reflect a fundamental shift in the object of judgment. Whereas in the classical period a crime was judged, in the modern period something else is being judged: "the passions, instincts, anomalies, infirmities, maladjustments, effects of environment or heredity."286 The judge no longer passes judgment on the criminal act, but on the soul of the convicted criminal and on his delinquence. ${ }^{287}$ These techniques are all embodied in the prison, the institution that colonized punishment during the late eighteenth and nineteenth centuries. ${ }^{288}$

What differs then in the three modalities of punishment - the monarchical law, the reformers' dreams, and the carceral society is not the theoretic basis of the right to punish, nor the leniency of the punishment, nor even its effectiveness on the subject. It is, instead, the way in which the punishment operates on the body and shapes the subject.

The difference is to be found in the procedure of access to the individual, the way in which the punishing power gets control over him, the instruments that it uses in order to achieve this transformation; it is in the technology of the penalty, not in its theoretical foundation; in the relation that it establishes with the body and with the soul, and not in the way that it is inserted within the legal system. ${ }^{289}$

285. Id. at 210 (translation of FouCAult, SURVEILler ET PUNIR, supra note 34, at 211); see also id. at 24 (translation of Foucault, SURveiller Et PUNIR, supra note 34, at 29).

286. Id. at 17 (translation of Foucault, Surverller ET Punir, supra note 34, at 23).

287. See id. at 18-19 (translation of Foucaurr, SuRveiller ET PUNIR, supra note 34, at 23-24).

288. Foucault argues, in Discipline and Punish, that the triumph of the prison in the modern period is a symptom of larger disciplinary processes that have infiltrated all aspects of life. See, e.g., id. at 231 (translation of Foucault, SurveIller ET PunIR, supra note 34, at 233) ("At the turn of the eighteenth and nineteenth centuries, there was, it is true, a penality of detention; and it was a new thing. But it was really the opening up of penality to mechanisms of coercion already elaborated elsewhere."). In effect, then, it is discipline, not just the prison, that colonized punishment in the modern period. See, e.g., id. at 209 (translation of Foucault, SurveIller ET PUNIR, supra note 34, at 211) ("The movement [to the prison] rests on a historical transformation: the gradual extension of the mechanisms of discipline throughout the seventeenth and eighteenth centuries, their spread throughout the whole social body, the formation of what might be called in general the disciplinary society.").

289. Id. at 127 (translation of Foucault, SuRvemler ET PUNIR, supra note 34, at 130). 
The three modalities differ as techniques, as arts of punishment. ${ }^{290}$ In their trilogy, they comprised: "[T] he sovereign and his force, the social body and the administrative apparatus; mark, sign, trace; ceremony, representation, exercise; the vanquished enemy, the juridical subject in the process of requalification, the individual subjected to immediate coercion; the tortured body, the soul with its manipulated representations, the body subjected to training."291

It is within this framework that we can begin to assess New York City's quality-of-life initiative. The policy of aggressive misdemeanor arrests bears a close resemblance to the juridical model in a number of respects. First, it bears the mark of sovereign excess. The idea of subjecting someone who has been, for instance, drinking in a public space to several hours in a cramped police van, to a strip search, to overnight detention, and to a criminal record bears the trappings of that imbalance between the subject and the sovereign that marked the more brutal punishments of the seventeenth century. The theory of punishment mirrors the early seventeenth century reliance on dissymmetry. Second, it has the trappings of the juridical - rather than normalizing - judgment: an all or nothing, guilty or innocent dichotomy. Discipline and normalization operate by creating a spectrum of comparison along which individuals can be differentiated, classified, and compared. In contrast, the classical juridical model was binary. As Foucault explains, the essential function of classical juridical penalty

is to refer, not to a set of observable phenomena, but to a corpus of laws and texts that must be remembered; [it] operates not by differentiating individuals, but by specifying acts according to a number of general categories; not by hierarchizing, but quite simply by bringing into play the binary opposition of the permitted and the forbidden; not by homogenizing, but by operating the division, acquired once and for all, of condemnation. 292

The quality-of-life initiative is, in this sense, the quintessential penal mechanism at the core of the disciplinary process. It is the juridical element in the panoply of disciplinary techniques, the juridical model embedded in a cluster of discipline. Foucault writes, "At the

290. See, e.g., id. at 257 (translation of Foucault, Surveiller ET PUNiR, supra note 34, at 261) ("The transition from the public execution, with its spectacular rituals, its art mingled with the ceremony of pain, to the penalties of prisons buried in architectural masses and guarded by the secrecy of administrations, is not a transition to an undifferentiated, abstract, confused penality; it is the transition from one art of punishing to another, no less skilful one. It is a technical mutation.").

291. Id. at 131 (translation of Foucault, SURVeiller ET PuniR, supra note 34, at 134).

292. Id. at 183 (translation of Foucault, SURVEILlER ET PUNIR, supra note 34, at 185). 
heart of all disciplinary systems functions a small penal mechanism."293 The quality-of-life initiative is precisely that mechanism.

At the same time, however, the quality-of-life initiative feeds into the disciplinary project by producing a subject to normalize the disorderly. By normalizing along the axis of disorder, the quality-of-life initiative breaks down and blends together the line between disorder and crime. Disorder becomes a degree of crime: breaking a window, littering, jumping a turnstile become grades along a spectrum that leads to homicide. The analogy, from Foucault, is to the penitentiary technique:

This vast mechanism established a slow, continuous, imperceptible gradation that made it possible to pass naturally from disorder to offence and back from a transgression of the law to a slight departure from a rule, an average, a demand, a norm.... You will end up in the convict-ship, the slightest indiscipline seems to say; and the harshest of prisons says to the prisoners condemned to life: I shall note the slightest irregularity in your conduct. ${ }^{294}$

Just like the category of the delinquent, the category of the disorderly breaks down the lines between minor infraction, minor disorder, and major offense. Moreover, as we saw earlier, the quality-oflife initiative also feeds into the disciplinary project of surveillance.

To say, however, that the quality-of-life initiative is part of the disciplinary project is to say too little - everything is today, since we live, according to Foucault, in a disciplinary society. Until such time as another paradigm presents itself, what we have to do today is compare the different genres of discipline. It is here that we can refine Foucault's analysis for there are many things that the qualityof-life is not. It is not modeled on the rehabilitative ideal central to many disciplinary projects, especially that of the mental hospital, welfare, and social work institutions. It does not feed into the psychotherapeutic. It does not coddle the disorderly. It does not aim so much to reform the disorderly as it does to punish them and to exclude them in the sense of getting them off the street. Insofar as the strategy does seek to influence their behavior, it does not employ the traditional rehabilitative methods. Nor does the qualityof-life initiative incorporate the concept of examination - the call-

293. Id. at 177 (translation of Foucault, SURVeIller Et PunIR, supra note 34, at 180).

294. Id. at 298-99 (translation of Foucault, Surveiller Et PunIR, supra note 34, at $306)$. 
ing card of school discipline. These are different subtypes of disciplinary techniques. ${ }^{295}$

New York's order-maintenance policing seems to draw more heavily both on the juridical model and the military form of discipline: the juridical insofar as it utilizes punishment that may seem somewhat excessive; military in the sense that it is normalized along an axis of disorder with a type of military observation, inspection, and exercise. Military discipline is captured in the ideal model of the military camp: "In the perfect camp," Foucault writes, "all power would be exercised solely through exact observation."296 The military space is designed "to act on those it shelters, to provide a hold on their conduct, to carry the effects of power right to them, to make it possible to know them, to alter them."297

Under this analysis, the weakness of the quality-of-life initiative is that it normalizes in a militaristic way along an axis of disorder even though there is inadequate empirical support. The disorderly may be the wrong target - or at least, there is not sufficient evidence to suggest that they are the right target. As we saw earlier, Skogan's data suggests that poverty, stability, and race - rather than disorder - may account for the discrepancies in neighborhood crime levels. This hypothesis needs to be further operationalized and verified. If it is true, however, then our normalizing, disciplinary practices should be reoriented along the axes of income, employment, and stability - and the issue of race should be directly addressed. If true, our policing and enforcement strategies should focus on workshop discipline, rather than on the juridical or military models - regardless of the fact that workshop discipline is a target of Foucault's critique.

Foucault's contribution is to shed light on how the techniques of punishment associated with the quality-of-life initiative create the category of the disorderly. The quality-of-life initiative focuses on the biography of the disorderly, rather than on the criminal act. It too judges the soul of the disorderly. It shapes the subject not simply by giving the individual a criminal record, and not simply by convicting the person. It shapes the subject by turning the individual into someone that needs to be policed, surveyed, watched, relo-

295. See Hugh Baxter, Bringing Foucault into Law and Law into Foucaul, 48 STAN. L. REv. 449, 455 (1996), for a somewhat similar interpretation of the different disciplinary technologies that Foucault deploys.

296. Foucautt, Discipline AND Punish, supra note 34 , at 171 (translation of Foucault, Surveiller et Punir, supra note 34, at 173).

297. Id. at 172 (translation of Foucault, SuRveILler Et PUNIR, supra note 34, at 174). 
cated, and controlled. It is in this sense that Foucault writes, regarding the analogous delinquent, that

[i]t is said that the prison fabricated delinquents; it is true that it brings back, almost inevitably, before the courts those who have been sent there. But it also fabricates them in the sense that it has introduced into the operation of the law and the offence, the judge and the offender ... the non-corporal reality of the delinquency that links them together and, for a century and a half, has caught them in the same trap. ${ }^{298}$

To say that the quality-of-life initiative shapes the disorderly subject is not to say that it promotes more disorderly conduct by labeling the individual as disorderly - whether or not that is true. It is, instead, to suggest that the theory of deterrence and punishment focuses on the whole biography of the disorderly person, rather than the criminal act; and thereby facilitates a policy of surveillance, control, relocation, and exclusion of the disorderly. ${ }^{299}$ In other words, the category of the disorderly is the product of the qualityof-life initiative and it promotes and facilitates a policy of aggressive arrest and detention.

\section{B. Foucault on Law}

Foucault's writings also offer an alternative interpretation of the role of legal order - an antithesis to the second prong of Durkheim's work. Whereas, for Durkheim, ordered legal regulation produces healthy moral cohesion (through the intermediary of the division of labor), for Foucault it is the disciplines that enforce moral cohesion under the cover of legal order. As a result, Foucault's writings on law are critical to appraise the social influence conception of deterrence. 300

298. Id. at 255 (translation of Foucault, SURVEILlER ET PuNIR, supra note 34, at 258).

299. The relationship and important differences between labeling theory in criminology and subject creation theory are complex and, clearly, beyond the scope of this Article. For present purposes, it is enough that subject creation theory, in contrast to labeling theory, does not necessarily suggest that the category of the disorderly creates more disorderly behavior on the part of the disorderly persons. $C f$. HowARD S. BECKER, OUTSIDERS: STUDIES IN THE Sociology OF Deviance 34 (1963) ("Treating a person as though he were generally rather than specifically deviant produces a self-fulfilling prophecy. It sets in motion several mechanisms which conspire to shape the person in the image people have of him."). The focus of my deployment of subject creation theory here is instead on the apparatuses of punishment and discipline that naturally flow from the category of the disorderly. For a classic expression of labeling theory, see id. at 31-35; THE OTHER SIDE (Howard Becker ed., 1964).

300. A number of scholars suggest that Foucault lacks a theory of law. Duncan Kennedy, in his essay The Stakes of Law, or Hale and Foucault!, criticizes Foucault for not taking law seriously enough. He argues that Foucault has an antiquated, pre-realist view of juridical power - "a typically European but utterly misconceived picture of the legal system as a domain governed by rules (as opposed to standards), by individualist (as opposed to altruist) 
For Foucault, law and discipline are very different from each other, and the tension between them gives rise to the modern carceral system and a new form of law, le pouvoir normalisateur. Discipline is a form of counter-law,, 01 of dissymmetry and inequality, that operates beneath the discourse of juridical power to make possible claims of equality and universal rights. Just as the discipline of the workshop molded men into workers and thereby enabled the industrial revolution to take place, ${ }^{302}$ general discipline shapes individuals into ordinary citizens, non-delinquents, and thereby makes it possible to speak about universal rights. At the same time, juridical discourse about human rights serves as a cover that allows disciplinary power to grow.

The democratization of rights discourse-resulting in claims of equality, humanity, and universality - has fueled the growth of disciplinary power. Equality permeates the idea of one carceral punishment for all, with different lengths of time measured according to

definitions of legal rights, and by deductive (as opposed to 'policy-oriented') reasoning." Duncan Kennedy, The Stakes of Law, or Hale and Foucault!, in SEXY Dressing, ETc. 83, 118 n.* (1993). According to Kennedy, "law and legal discourse play superstructural and mystificatory roles in Foucault's disciplinary society analogous to their roles in Marx's political economy." Id. at 122. Similarly, Alan Hunt and Gary Wickham, in their recent book Foucault and Law, charge that "Foucault does not have a theory of law" and that he "tends to expel law from any major role in modern forms of government." ALAN HuNT \& GarY WICKHAM, FouCAult AND LAW viii, 22 (1994). Hugh Baxter agrees. "A straightforward reading of Foucault's writings on power suggests, as Hunt and Wickham observe, that Foucault tends to 'expel law from any significant role' in modern society." Baxter, supra note 295, at 461. Baxter continues: "Foucault's conception of law as sovereign command is too crude a tool for understanding modern law." Id. at 464.

Law, however, is by no means an untheorized concept for Foucault. To the contrary, law is at the heart of Foucault's project. In fact, in Foucault's stated purpose - "a genealogy of the present scientifico-legal complex from which the power to punish derives its bases, justifications and rules," Foucault, Discipline AND Punish, supra note 34, at 23 (emphasis added) (translation of Foucault, Surveiller ET Punir, supra note 34, at 27) - law and knowledge play equally important roles. The discussion in text will bear this point out. See also id. ("Instead of treating the history of penal law and the history of the human sciences as two separate series... see whether there is not some common matrix or whether they do not both derive from a single process of 'epistemologico-juridical' formation." Id. (translation of Foucault, Surveiller et Punir, supra note 34, at 28)).

301. Scholars have suggested that this idea of discipline as counter-law represents the expulsion of law in Foucault's work. See, e.g., Baxter, supra note 295, at 454 ("The opposition between law-as-sovereign-power, on one hand, and disciplinary power, on the other, is one of the key themes of Foucault's work on power. It will also turn out to be essential to Foucault's 'expulsion of law' from modernity."). However, as discussed infra, it is precisely this opposition that fuels both legal and disciplinary power. Law thus provides a critical mechanism in modernity.

302. See Foucault, Discipline ANd Punish, supra note 34, at 221 (translation of Fou. CAULT, SURVEILlER ET PUNIR, supra note 34, at 222) (discussing the industrial revolution). Foucault suggests that the infusion of disciplinary power in the industrial complex made possible the industrial revolution by shaping the modern worker. Foucault refers in a footnote to Marx's Das Kapital, and thereby indicates some economic implications of his study of disciplinary power. 
the delinquency of the individual. Humanity also permeates the idea of incarceration as reflected in the notion that "the penalty must be nothing more than the deprivation of liberty."303 And the claim of universality justifies the power to punish. Together, these juridical claims have empowered and facilitated the growth of the carceral system. Legal discourse has allowed the disciplines to flourish.

Foucault describes this interplay between juridical and disciplinary power in his Two Lectures as follows:

[T] he theory of sovereignty, and the organization of a legal code centred upon it, have allowed a system of right to be superimposed upon the mechanisms of discipline in such a way as to conceal its actual procedures, the element of domination inherent in its techniques, and to guarantee to everyone, by virtue of the sovereignty of the State, the exercise of his proper sovereign rights. The juridical systems - and this applies both to their codification and to their theorization - have enabled sovereignty to be democratized through the constitution of a public right articulated upon collective sovereignty, while at the same time this democratization of sovereignty was fundamentally determined by and grounded in mechanisms of disciplinary coercion. ${ }^{304}$

Modern society, for Foucault, is defined then by this conjunction of legal discourse - rights talk - and disciplinary coercion. The carceral system is constructed within a space constituted by both. ${ }^{305}$ The confrontation produces a new tendency, a process of normalization that simultaneously creates the delinquent and justifies the power to punish. ${ }^{306}$ This normalizing power defines and categorizes

303. Foucault, Disctpline AND PUnish, supra note 34, at 248 (translation of FouCAULT, SURVEILler ET PUNIR, supra note 34, at 251).

304. Michel Foucault, Two Lectures, in Power/Knowledge: Selected InTerviews AND Other WrTtings, 1972-1977, at 78, 105 (Colin Gordon ed., Colin Gordon et al. trans., Pantheon Books 1980) [hereinafter Foucault, Two Lectures]. Foucault makes the same point in Foucault, Discipline and PunIsh, supra note 34, at 221-22 (translation of Fou. CAULT, SURVEILLER ET PUNIR, supra note 34, at 223-24). This passage represents the crux of my difference with Hunt, Wickam, and Baxter. While these scholars dismiss this discussion, see HuNT \& WickraM, supra note 300, at 61-62; Baxter, supra note 295, at 462-63, I believe that it is at the center of Foucault's discussion of law.

305. See Foucault, Two Lectures, supra note 304, at 104-08. "The powers of modern society are exercised through, on the basis of, and by virtue of, this very heterogeneity between a public right of sovereignty and a polymorphous disciplinary mechanism." Id. at 106.

306. Foucault writes:

With this new economy of power, the carceral system, which is its basic instrument, permitted the emergence of a new form of "law": a mixture of legality and nature, prescription and constitution, the norm. This had a whole series of effects: the internal dislocation of the judicial power or at least of its functioning; an increasing difficulty in judging, as if one were ashamed to pass sentence; a furious desire on the part of judges to judge, assess, diagnose, recognize the normal and abnormal and claim the honour of curing or rehabilitating. ... The judges of normality are present everywhere. We are in the society of the teacher-judge, the doctor-judge, the educator-judge, the "socialworker"-judge. . . . The carceral network, in its compact or disseminated forms, with its 
the delinquent, surveys all aspects of his existence and gives rise to the human sciences whose object is that individual. This normalizing power is neither wholly disciplinary, nor entirely juridical. It is a mixture. It contains both elements, ${ }^{307}$ and it justifies the power to punish. ${ }^{308}$

\section{The Implications for the Social Influence Conception of Deterrence}

This reading of Foucault challenges us to rethink the social influence conception of deterrence. I will summarize here in brute simplicity the concrete implications. First, the quality-of-life initiative may create the category of the disorderly. Second, the category of the disorderly may facilitate a policy of aggressive arrests, with the possibility of attendant brutality, even though such a policy is unlikely to have the slightest effect on crime rates. Third, the interplay of the norm of orderliness (discipline) and the ideals of justice (law) may succeed in blinding us to the disorder that accompanies the quality-of-life initiative.

The social influence theory of deterrence concentrates on the construction of social meaning, ${ }^{309}$ but fails to pay enough attention to the way that social meaning constructs the subject and to the way that our understanding of the subject fosters certain forms of disciplinary strategies. It does not pay enough attention to the way that social meaning allows us to treat the disorderly as deviant and outside the realm of our legal ideals, or to the way that social mean-

systems of insertion, distribution, surveillance, observation, has been the greatest support, in modern society, of the normalizing power.

Foucault, Discipline AND PUNISH, supra note 34, at 304 (translation of Foucault, SURVEILler ET PUNIR, supra note 34, at 310-11).

307. It is important for Foucault that both juridical and disciplinary power be part of the new law. Thus, Foucault writes in Two Lectures:

I believe that the process which has really rendered the discourse of the human sciences possible is the juxtaposition, the encounter between two lines of approach, two mechanisms, two absolutely heterogeneous types of discourse: on the one hand there is the reorganisation of right that invests sovereignty, and on the other, the mechanics of the coercive forces whose exercise takes a disciplinary form. And I believe that in our own times power is exercised simultaneously through this right and these techniques and that these techniques and these discourses, to which the disciplines give rise invade the area of right so that the procedures of normalisation come to be ever more constantly engaged in the colonisation of those of law. I believe that all this can explain the global functioning of what I would call a society of normalisation.

Foucault, Two Lectures, supra note 304, at 107.

308. See Foucault, Discipline AND Punish, supra note 34, at 224 (translation of Foucault, Surveiller ET Punir, supra note 34, at 225) ("Ce qui généralise alors le pouvoir de punir, ce n'est pas la conscience universelle de la loi dans chacun des sujets de droit, c'est l'étendue régulière, c'est la trame infiniment serrée des procédés panoptiques."). 72.

309. See'Kahan, Social Influence, supra note 12, at 370-71; Lessig, supra note 16, at 962 - 
ing allows us to implement a policy of aggressive misdemeanor arrests without noticing it. This reading of Foucault explains how. In discussing modern society, Foucault writes:

$[P]$ erhaps the most important effect of the carceral system and of its extension well beyond legal imprisonment is that it succeeds in making the power to punish natural and legitimate, in lowering at least the threshold of tolerance to penalty. It tends to efface what may be exorbitant in the exercise of punishment. 310

This may explain why we so easily ignore what it would actually be like to be arrested, handcuffed, booked, transported, strip-searched, jailed, and given a criminal record for a minor misdemeanor offense. We have so internalized the norm of orderliness that even those among us who favor social norms and seek alternatives to incarceration disregard the fact that the quality-of-life initiative relies so extensively on law enforcement, arrest, and incarceration. We are blinded because, after all, the people being arrested are disorderly - they have committed crimes. ${ }^{311}$

This reading of Foucault differs from that of social norm proponents. Lawrence Lessig writes: "Michel Foucault's work is another example [of the evolution of social meaning], though his is an account focused less on meaning, and more on the 'meticulous observation of detail' constructing structures of power and discipline in social life." 312 Under my reading, Foucault is not so much concerned with the evolution of social meaning for its own sake, though the evolution of social meaning is crucial to his enterprise. Foucault is primarily concerned with the way that social meaning shapes the subject; his ultimate focus is not on social meaning, but on the subject. That is the sense in which he famously stated that all his writings were not about power, but rather an attempt "to

310. Foucault, Discipline AND PUNISH, supra note 34, at 301 (translation of Foucault, Surveiller et Puntr, supra note 34, at 308). "It does this by playing the two registers in which it is deployed - the legal register of justice and the extra-legal register of discipline - against one another." Id. at 301-02 (translation of FOUCAULT, SURVEILLER ET PuniR, supra note 34 , at 308 ).

311. After all, criminals continue to be, today, a class of people that many feel entitled to hate and exclude. See Kathlyn Taylor Gaubatz, Crime in the Public Mind (1995) (empirical data regarding public opinion about criminal justice); BONNIE HoNIG, POLITICAL THEORY AND THE Displacement OF Polmics 126-61 (1993) (Rawls excludes criminality from the original position and thereby marginalizes the criminal); Richard Posner, Emotion versus Emotionalism in Law, Paper Delivered Before the Conference on Emotions and the Law (May 23, 1998) ("I do not consider it immoral to hate criminals, philanderers, braggarts, or even beggars (who in today's America are mainly a species of con man).").

312. Lessig, supra note 16 , at 962 : 
create a history of the different modes by which . . . human beings are made subjects." 313

Now, to be sure, the new path of deterrence does overlap somewhat with subject creation. Under the social influence conception, law and the social environment affect - maybe even shape - the individual's conduct. "The decisions of individuals to commit crimes," Kahan writes, "are influenced by their perception of others' beliefs and intentions; the law shapes information about what those beliefs and intentions are."314 But social meaning influences persons differently depending on their category, and the difference is crucial to the social influence explanation: honest people leave the neighborhood, whereas the disorderly invade. Social influence operates on pre-existing categories.

The relationship between social influence theory and the critique that I have offered here can be illustrated in the following diagram. At the heart of the diagram is the social influence theory (from Fig. 1 supra). Superimposed over the social influence theory is my critique, with its three principal moments. Those moments are (1) subject creation: how the norm of order may create the categories of honest and disorderly; (2) facilitation: how the categories may promote a policy of arrest, despite the lack of evidence of deterrence; and (3) overpowering: how the interplay between discipline and law may blind us to disorder.

313. Michel Foucault, The Subject and Power, Afterword to Hubert L. Dreyfus \& Paul Rabinow, Michel Foucault: Beyond Structuralism and Hermeneutics 208, 208 (2d ed. 1983). Foucault makes this point, in fact, in the passage quoted by Lessig, where Foucault writes:

A meticulous observation of detail, and at the same time a political awareness of these small things, for the control and use of men, emerge through the classical age bearing with them a whole set of techniques, a whole corpus of methods and knowledge, descriptions, plans and data. And from such trifles, no doubt, the man of modern humanism was born.

Foucault, Discipline and Punish, supra note 34, at 141 (emphasis added) (translation of Foucault, Surveiller Et PunIR, supra note 34, at 143).

314. Kahan, Social Influence, supra note 12, at 351. 
FIGURE 3:

Challenging the Categories Underiying the Social Influence Conception of DeterRence

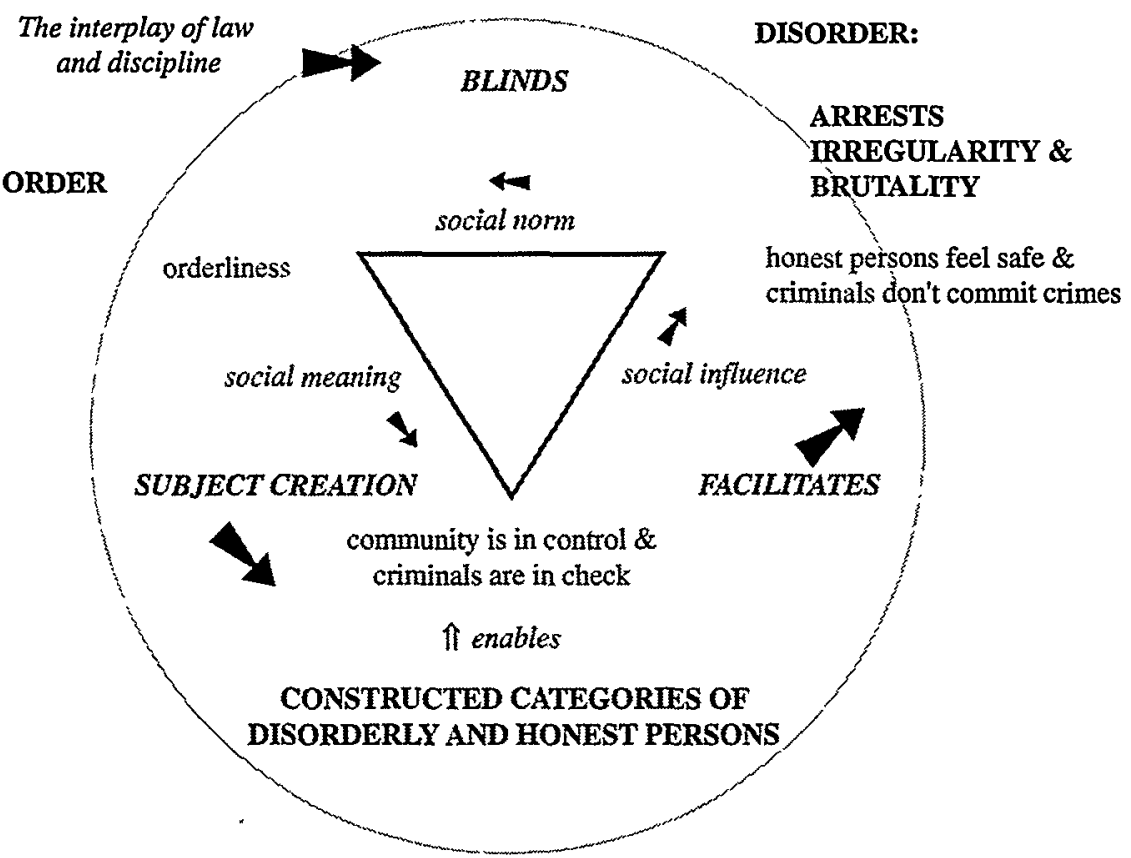

The diagram attempts to incorporate the principal implications and show how they relate to - and in effect enable - the social influence conception of deterrence. These implications, of course, raise a number of questions. Is it true, in fact, that the categories facilitate a policy of aggressive arrests? Is there evidence of police brutality? Are there alternatives to arrest?

\section{Subject Creation in Contemporary Criminal Law Scholarship}

Before answering these questions and suggesting policy implications, it may be worth pausing, for a moment, to see how this critique of Durkheim's sociological approach - and, correspondingly, of the social influence conception of deterrence - is reflected in contemporary scholarship in criminal law. While some scholars explicitly deploy subject creation theory, ${ }^{315}$ I would like to focus here

315. See, e.g., Dorothy E. Roberts, Crime, Race, and Reproduction, 67 TuL. I. REv. 1945 (1993); Dorothy E. Roberts, Punishing Drug Addicts Who Have Babies: Women of Color, Equality, and the Right of Privacy, 104 HARV. L. REv. 1419 (1991); Jonathan Simon, Ghosts of the Disciplinary Machine: Lee Harvey Oswald, Life-History, and the Truth of Crime, 10 YAlE J.L. \& Human. 75 (1998); Robert Weisberg, The New York Statute as Cultural Document: Seeking the Morally Optimal Death Penalty, 44 BuFF. L. REv. 283 (1996); Jonathan A. 
on two articles that rely on different intellectual traditions to show how pervasive the insight of subject creation is in the criminal law. The two articles are John Griffiths's Ideology in Criminal Procedure or A Third 'Model' of the Criminal Process ${ }^{316}$ and Carol and Jordan Steiker's Sober Second Thoughts: Reflection on Two Decades of Constitutional Regulation of Capital Punishment. ${ }^{317}$ This discussion may help illustrate how subject creation theory can be deployed in the context of the social influence conception of deterrence.

In Ideology in Criminal Procedure, John Griffiths challenges the categories of the criminal and the committed law abider. Griffiths approaches this task from a different intellectual tradition, namely from the tradition of critical theory of the Frankfurt School. His article was published in 1970, several years before the publication of Discipline and Punish, yet it reflects, in a number of ways, Foucault's critique. ${ }^{318}$

Griffiths's article is a critique of ideology in the traditional critical theory sense. ${ }^{319}$ His challenge to the underlying categories is framed as an attack on a certain form of ideology in criminal procedure. ${ }^{320}$ Griffiths's project is to expose the prevailing ideology in order to make possible alternative conceptions that are presently foreclosed by the operative categories that dominate present thinking. "American thought about criminal procedure," Griffiths writes, "is confined within a prevailing ideology. By describing an

Willens, Structure, Content and the Exigencies of War: American Prison Law After TiventyFive Years, 1962-1987, 37 AM. U. L. REv. 41 (1987).

316. John Griffiths, Ideology in Criminal Procedure or A Third "Model" of the Criminal Process, 79 YALE L.J. 359 (1970).

317. Carol S. Steiker \& Jordan M. Steiker, Sober Second Thoughts: Reflections on Two Decades of Constitutional Regulation of Capital Punishment, 109 HARv. L. REv. 357 (1995).

318. This discussion touches upon the larger issue of the relationship between Foucault and Critical Theory, a fascinating and complex topic that is beyond the scope of this Article. For entry into that discussion, see Habermas's dialogue with Foucault in CRITIQUe AND Power: Recasting the Foucault/Habermas Debate (Michael Kelly ed., 1994); see also Axel Honneth, The Critique of Power (Kenneth Baynes trans., 1991).

319. See Griffiths, supra note 316; see also RAymond Geuss, THE IDEA OF A Critical THEORY: HABERMAS AND THE FrankFuRT SCHOOL 22-26 (1981).

320. Griffiths explains:

I use the word [ideology] to refer to that set of beliefs, assumptions, categories of understanding, and the like, which affect and determine the structure of perception (not only of physical phenomena, like causation, which has consumed the interest of philosophers, but also, and most particularly here, of social facts, relationships and possibilities). Ideological beliefs are pre-logical because they determine the structure of perception and consciousness and therefore are enmeshed in the factual and linguistic premises of argument. It is only self-consciousness concerning the existence and nature of ideology which permits an appreciation of the extent to which it determines the contents of the world of experience and possibility. Self-consciousness is therefore the primary intellectual virtue.

Griffiths, supra note 316 , at 359 n.1. 
alternative, I shall seek to illustrate that our present assumptions are not the inevitable truths they often seem to be." 321

Griffiths describes the prevailing ideology of criminal procedure as premised on the assumption of an irreconcilable conflict between the state and the individual defendant. He calls this the "Battle Model" and suggests that it encompasses both of Herbert Packer's famous models of criminal process - both the Due Process Model, which insists on the priority of the individual and the limits on official power, and the Crime Control Model, which privileges law enforcement and speedy and efficient resolution of charges. The Battle Model, though, has built-in constraints. Like any other ideology, it reinforces certain categories that ultimately limit possible outcomes. So Griffiths writes:

[W]e can clearly see the ideological limits within which [Packer's] conception of two Models is confined: despite his intention to lay bare the entire spectrum of procedural possibility, the two Models in fact give us only that which is relevant to a particular and limited conception of the substantive function of criminal law - prevention and retribution. 322

As an alternative to the Battle Model, Griffiths offers an approach to criminal procedure based on the ideology of the family. ${ }^{323}$ Instead of assuming, as Packer does, "disharmony, fundamentally irreconcilable interests, a state of war" between the individual and the State, Griffiths proposes to "start from an assumption of reconcilable - even mutually supportive - interests, a state of love."324

Under a "Family Model," Griffiths suggests, there would be an entirely different conception of the criminal. Rather than the criminal being viewed as someone to be deterred or incapacitated, the Family Model would look upon him or her as a wayward son or daughter in need of guidance. The Family Model would trigger acceptance of the idea that criminals are just people who are deemed to have offended - that we are all of us both actual and potential criminals - that "criminals" are not a special kind and class of people with a unique relation to the state. So adherents to the Family Model would not talk (or think) about "offenders," or "criminals," or "people who commit crimes," as if these words referred to people in any other aspect than their exposure to the criminal process. ${ }^{325}$

321. Id. at 359-60.

322. Id. at 366 .

323. Griffiths's writings on the Family Model resonate strongly in contemporary criminology. See, e.g., BraIthwaITe, supra note 244, at 56-57; see generally Michael R. Gotifredson \& Travis Hirschi, A Generai Theory of Crime (1990).

324. Griffiths, supra note 316 , at 371.

325. Id. at 374. 
Griffiths draws attention to a number of implications. For example, the role of the criminal defense attorney would fundamentally change. Defense counsel would no longer stop representing their clients at sentencing, but would instead remain involved throughout the incarceration and during the transition back into the free world. ${ }^{326}$

Griffiths's article shares two central theses with subject creation theory: first, he suggests that, in the traditional Battle Model, the categories of criminals and honest persons are unexamined and prelogical conceptions that have broad and, again, unexamined, consequences for policymaking; and, second, that these categories are themselves constructed and reinforced by legal ideology. There is a self-reinforcing nature to the relationship between the categories and public policies. The public policies assume the categories, reinforce the categories, but also follow from the categories.

There are, of course, significant differences between Griffiths and Foucault, not the least of which concern the method of exposition. As noted earlier, Griffiths proposes, but disavows the Family Model. He claims to deploy it merely as a technical device. ${ }^{327}$ The underlying assumption is that, confronted with an alternative way of conceptualizing the world, the reader will become conscious of the limitations of the prevailing ideology. It is, in a sense, a shock therapy. The juxtaposition is supposed to jump-start our imagination..$^{328}$ His method differs from Foucault's intricate genealogical enterprise, but his critique of the categories plays a very similar role.

Griffiths's work is not primarily concerned with the interrelationship between discipline and law. ${ }^{329}$ This concern is reflected in

326. See id. at $380,383$.

327. See id. at 359-60 ("By describing an alternative, I shall seek to illustrate that our present assumptions are not the inevitable truths they often seem to be. The alternative presented is not especially novel, nor is it one to which I necessarily subscribe. My purpose is merely to explore the problem of ideology in criminal procedure, and to that end the selfconscious posing of an alternative is justified by its heuristic value."). One does get the impression, though, that Griffiths favors the Family Model. This is perhaps most clear in his conclusion. See id. at $410-17$.

328. Griffith explains:

This brings me to my ultimate conclusion, which is that speculation about fundamental change in criminal procedure must begin with the development of ideological selfconsciousness and speculation about the possibilities of ideological change.... [t] t seems to me that very little substanial [sic] progress is to be made in thinking about criminal procedure until we address ourselves to the ideological underpinnings of our thought.

The first step in doing that is simply to set our minds free to wonder.

Id. at 417.

329. Griffiths does, though, address the disciplinary aspects of legal ideology, in particular the effect of criminal procedure on the different classes in society. See id. at 414-16. 
Carol and Jordan Steiker's work on capital punishment, especially their most recent article, Sober Second Thoughts. ${ }^{330}$ The authors explore there the development of death penalty law over the past two decades. They suggest that today's intricate Eighth Amendment jurisprudence is deeply flawed in that it fails to offer substantive protection against arbitrariness or to fulfill the original aspirations of fairness, individualization, reliability, and just desert. They question why such a deeply flawed body of law would persist, despite its tragic failure as a regulatory mechanism, and come up empty handed. Ultimately, the authors conclude that they were simply asking the wrong question: "Instead of asking why the Court's doctrine has persisted despite its failure as regulation, perhaps we should be asking whether that doctrine has any effect $b e$ sides its failure as regulation." 331 The effect, it turns out, is legitimation. ${ }^{332}$ The authors explain:

Perhaps the Justices have retained current death penalty doctrine despite its failings as a house because at some level they appreciate its success as a facade. The Court's doctrine can be said to work as a facade to the extent that it is successful - and we argue below that it is - at making participants in the criminal justice system and the public at large more comfortable with the death penalty than they otherwise would be or should be. ${ }^{333}$

Drawing on the Weberian tradition of legitimation and the writings of Antonio Gramsci, Carol and Jordan Steiker explore how legitimation theory might explain, as an unintended consequence, the persistence of death penalty jurisprudence. The authors conclude that " $[t]$ he Supreme Court's death penalty law, by creating an impression of enormous regulatory effort while achieving negligible regulatory effects, effectively obscures the true nature of our capital sentencing system" and thereby "legitimates the imposition of capi-

330. Steiker \& Steiker, supra note 317.

331. Id. at 437.

332. Duncan Kennedy has contributed importantly to the tradition of legitimation theory. See DunCan Kennedy, A CRIrIoue of AdJudication (FIN DE SIEClE) (1997), where Kennedy develops what he calls "Pink Theory," or a chastened version of legitimation. See id. at 293 ("What is legitimated is the status quo, rather than capitalism or the relations of production understood as a structure. The status quo is an incoherent hodgepodge of heterogeneous elements, without a system logic. Whatever it may be at any given moment, that's what gets naturalized by the denial of the ideological element in judicial law making."). For an earlier contribution, see David M. Trubek, Complexity and Contradiction in the Legal Order: Balbus and the Challenge of Critical Social Thought About Law, 11 L. \& Socy. Rev. 529 (1977), where Trubek sketches a critical-socio-legal theory premised on a similar concept of legitimacy. According to Trubek, it is the myth of judicial neutrality that allows the modern soul to mediate the ideal of equality with the reality of inequality. So Trubek writes, "As members of a liberal society, we embrace the ideals and yet are aware of their negation. The idea of law offers the possibility of escape from this contradiction." Id. at 541.

333. Steiker \& Steiker, supra note 317, at 429. 
tal punishment both for participants in the legal system and for the public at large."334

Carol and Jordan Steiker's thesis has a lot in common with Foucault's writings on law, even though it traces to a very distinct intellectual tradition. In their article, law is a cover for the underlying micro-processes of politics. Like Foucault, law is the medium that allows the disciplines to thrive. Law is what reconciles participants to the reality of inequity despite shared ideals of equality and freedom. In sum, the authors suggest, law serves to bridge the gap between the coercive and inequitable micro-processes of discipline and the legal ideals of equality and fairness.

The Griffiths and Steiker articles bear a strong family resemblance to subject creation and, together, they make moves very similar to the two principal critiques discussed earlier: the critique of the underlying categories and the critique of law. These examples of contemporary criminal law scholarship suggest that subject creation is perhaps a more widely shared insight than commonly recognized. I have chosen two illustrations, but there are many other examples of criminal law scholarship that share this insight even though they may come from entirely different traditions, such as the emerging field of Therapeutic Jurisprudence ${ }^{335}$ or the writings of Elizabeth Schneider on the battered woman syndrome. ${ }^{336}$ Subject creation has significant implications for the criminal law. It is to

\section{4. $I d$. at 436 .}

335. Therapeutic Jurisprudence is an interdisciplinary approach to law developed by David Wexler and Bruce Winick. See generally LaW in a Therapeutic Key: Develop. MENTS IN Therapeutic Jurisprudence (David B. Wexler \& Bruce J. Winick eds., 1996) [hereinafter LAw IN A TherAPEUTIC KEY]. It is premised on the idea that "whether we realize it or not, law functions as a therapeutic agent, bringing about therapeutic or antitherapeutic consequences." Bruce J. Winick, The Jurisprudence of Therapeutic Jurisprudence, in LAW IN A THERAPEUTIC KEY, supra, at 645 , 648. The following questions are representative of the issues that Therapeutic Jurisprudence addresses:

Can a judge's colloquy with a criminal defendant at a plea hearing influence the defendant's acceptance of responsibility? Can a judge conduct a sentencing hearing in a manner likely to increase a criminal defendant's compliance with conditions of probation? Is "sentencing bargaining" less likely to interfere with later efforts at offender rehabilitation than "charge bargaining"? Can "teen courts" increase empathy in delinquent youths by having those youths serve as attorneys for victims in teen court proceedings?

Id. at 650. Allison Shiff and David Wexler's discussion of teen courts, a relatively recent development in the juvenile court system dating back to about 1983, is a good illustration of the possible overlap of subject creation theory and the Therapeutic Jurisprudence approach. See Allison R. Shiff \& David B. Wexler, Teen Courts: A Therapeutic Jurisprudence Perspective, in LAW IN A THERAPEUTIC KEY, supra, at 287, 293.

336. See Elizabeth M. Schneider, Describing and Changing: Women's Self-Defense Work and the Problem of Expert Testimony on Battering, 14 WOMEN's RTs. L. REP. 213, 232-34 (1992) (discussing how the battered woman syndrome can be deployed against women by placing them in the category of crazy, helpless, or both). 
these implications in the context of order-maintenance policing that I shall now turn.

\section{Revisiting Order-Maintenance Policing}

We are left with a disarming theory without empirical support - with a type of aesthetic policing that focuses on the disorderly. The social influence conception of deterrence and the broken windows theory appropriate the aesthetic of order and sobriety, and, at the same time, empower the police as the only rival to the disorderly. By commandeering the aesthetic categories, the theory leaves most of its interlocutors speechless. Very few contest the policing strategy - even though the broken windows theory, especially as implemented in New York City, leads to a false choice. No one in their right mind would choose the gangs, the criminals, or the disorderly. No reasonable person would advocate disorder, littering, panhandling, or prostitution. No one seriously would come out in favor of breaking windows - even if, as the Broken Windows essay playfully suggests, "It has always been fun."337

In the previous sections, I traced the problem back to the underlying category of the disorderly and suggested how that category is the product of the punitive strategy and simultaneously facilitates the law enforcement policy. I suggested that the category of the disorderly may blind us from seeing the irregularities that accompany the quality-of-life initiative - from seeing the disorder in the order. But what is the order masking?

\section{A. Complaints of Police Brutality and the NYPD}

The aesthetic of order has overshadowed, in New York City, a sharp increase in complaints of police brutality. At a theoretic level, this may not be entirely surprising. After all, the Broken Windows essay betrays itself. In place of the struggle between order and disorder, the text reveals two competing sources of power, two competing forces of social-control. The "police view," according to Wilson and Kelling, is that "the cops and the gangs are the two rival sources of power in the area, and that the gangs are not going to win." 338 This bears a striking resemblance to former Commissioner Bratton's statement that "criminals are our competition." 339 Bob Herbert of the New York Times reports a chilling ex-

337. Wilson \& Kelling, supra note 2, at 31.

338. Id. at 35 .

339. See Beiser, supra note 199 , at 39. 
change between a police officer from the Bronx and a commission investigating police misconduct:

"Did you beat people up who you arrested?"

"No. We'd just beat people in general. If they're on the street, hanging around drug locations. It was a show of force."

"Why were these beatings done?"

"To show who was in charge. We were in charge, the police."340

In New York City, complaints of police brutality have been on the rise since the inception of the quality-of-life initiative. According to the New York Times, "from 1994 to 1996, the city received 8,316 court claims of abuse by officers, compared with 5,983 for the three previous years." In addition, the Times reports, "from 1994 to 1996 , the city paid about $\$ 70$ million as settlements or judgments in claims alleging improper police actions - compared with about $\$ 48$ million in the three previous years." 341 The Times also reports that "accusations of misconduct filed with the Civilian Complaint Review Board have risen sharply during much of Mayor Giuliani's tenure." 342 Although the number of complaints filed with the CCRB fell by twenty-two percent in the first six months of 1997,343 the number appears to be on the increase again in 1998. Complaints lodged with the CCRB are up twenty percent for the first five months of 1998: the CCRB received 2,176 complaints against police officers for the period January through May 1998, in contrast to 1,818 complaints during the same period last year. ${ }^{344}$ The trend is reflected in the following table: ${ }^{45}$

\section{Table 14: CCRB Complaints and Allegations,} $1993-1998$

$\begin{array}{llllllc} & 1993 & \frac{1994}{4877} & \frac{1995}{5618} & \frac{1996}{5550} & \frac{1997}{4816} & \frac{\text { Jan - May 1988 }}{\text { Complaints }} \\ \text { Allegations } & 5580 & 8060 & 9356 & 9390 & 7183 & \mathrm{n} / \mathrm{a}\end{array}$

340. Bob Herbert, Connect the Dots, N.Y. Times, Aug. 24, 1997, § 4, at 13.

341. Purdy, supra note 11.

342. Id.

343. See id.

344. See Complaints Against Police Rise, N.Y. Tmes, June 11, 1998, at A25 (Digest: The New York Region) ("[A]ccording to the statistics released yesterday by the CCRB").

345. See id.; Fax from Sherman Jackson of the CCRB, supra note 38, at 4 (June 17, 1997) (on file with author); see also New York Civil Liberties Union, NYCLU Report: A Fourth Anniversary Overview of the Civilian Complaint Review Board, July 5, 1993 - July 5, 1997 tbl.2 (1997) [hereinafter NYCLU Report] (presenting data on the CCRB's disposition of complaints from July 1993 to December 1996). 
These trends are corroborated by a controversial report issued by Amnesty International in June 1996 entitled, Police Brutality and Excessive Force in the New York City Police Department. ${ }^{346}$ Some have questioned the accuracy of Amnesty's reporting;347 however, for the very limited purpose of this Article, Amnesty's report merely lends further support to the already well documented increase in complaints of police brutality. Amnesty reported that complaints of police brutality in New York City "have been rising steadily for some years." 348 According to Amnesty's statistics, "the number of people bringing claims for police misconduct against the City of New York has increased substantially in recent years, from 977 in 1987 to more than 2,000 in 1994." Furthermore, "[t]he amount paid out by the city each year in settlements or judgments awarded to plaintiffs in police abuse cases has also risen," from around $\$ 13.5$ million in 1992 to more than $\$ 24$ million in $1994 .{ }^{349}$ Amnesty also found an increase in complaints lodged with the $\mathrm{CCRB}$, as well as racial disparities among complainants. ${ }^{350}$

Police officials suggest that the increase in complaints of police brutality may be due to the increase in the number of arrests associated with the quality-of-life initiative. Former Commissioner Bratton minimizes the significance of the numbers, suggesting that "complaints always rise after there is a large influx of new police officers." 351 Police Commissioner Safir attributes the most recent upsurge in complaints filed with the CCRB in 1998 to the fact that the Abner Louima case has brought increased attention to the question of police brutality. ${ }^{352}$ Perhaps these explanations are cor-

346. Amnesty International, United States of America: Police Brutality and Excessive Force in the New York City Police Department (AI Index AMR 51/36/96 1996), available at <http://www.amnesty.org//ailib/airpub/1996/AMR/25103696.htm> [hereinafter Amnesty Report].

347. Tracey Meares has suggested to me that the report may be unreliable; however I have not located any published scholarship challenging the methodology of the report.

348. Amnesty Report, supra note 346, at 14.

349. Id. at 3, 14.

350. See id. ("The CCRB reported that it received 4,920 new complaints in 1994, an increase of $37.43 \%$ over the previous year. While the CCRB takes complaints covering a range of alleged abuses from deadly force to discourtesy, 1,670 complaints (the largest proportion) were for excessive force and these had also risen proportionately from 1993."). Amnesty also reports that "the large majority of the victims of police abuses are racial minorities, particularly African-Americans and people of Latin American or Asian descent. Racial disparities appear to be especially marked in cases involving deaths in custody or questionable shootings." Id. "Three-quarters (75.9\%) of the people who lodged complaints with the CCRB from January to June 1995 were African-American $(50.3 \%)$ and Latino $(25.6 \%)$, while the remainder were either white $(21.2 \%)$ or 'other' $(2.8 \%)$, including Asian." Id.

351. Bratton, supra note 8.

352. See Complaints Against Police Rise, supra note 344. 
rect; however, there are some reasons to be somewhat skeptical. The CCRB reported to Amnesty delegates that "most of the complaints arose from encounters with patrol officers that did not involve arrests or persons receiving summonses."353 Moreover, the $\mathrm{CCRB}$ also reported that "most complainants had no prior complaint history, thus discounting suggestions that many of those lodging complaints were 'chronic' complainers."354 In addition, although rookie police officers may account, in some part, for the rise in complaints of police brutality, the complaints seem to have increased at a greater pace than the rate of increase of incoming officers. ${ }^{355}$ In this regard, it would be crucial to determine empirically whether the increase in complaints involves new police officers.

I am not arguing, nor have I attempted to establish, that there is a causal link between the quality-of-life initiative and the increase in complaints of police brutality. Nor have I argued that there is an empirical link between order-maintenance policing and police brutality. The fact that order-maintenance policing in New York City has coincided with an increase in complaints of police brutality does not, in itself, establish a causal relationship. The possible explanations for the increase in the number of complaints are far too complex to lend themselves to such a conclusion. Moreover, even if such a causal relationship were empirically verified, it does not necessarily militate against order-maintenance policing. It could be that order-maintenance policing can be implemented without the attendant increase in complaints of police brutality. Or it could be that we are prepared to pay the price of police brutality for the benefits of the policing strategy.

What I am suggesting, though, is that the issue of increased complaints of police brutality may be overshadowed by the rhetoric of order and cleanliness surrounding the quality-of-life initiative. Why is it, after all, that the issue of police brutality and the causes of brutality are not on the research agenda along the new path of deterrence?356 Why is it that the police disorder within ordermaintenance policing is minimized in the Broken Windows essay?

353. Amnesty Report, supra note $346, \S 2.9$.

354. Id.

355. See, e.g., NYCLU Report, supra note 345, at 4 n.6 ("The 27 percent increase in the NYPD's complement of sworn officers in recent years (from approximately 30,000 to 38,000 ) does not begin to explain a 60 percent increase in police misconduct complaints.").

356. See, e.g., Kahan, Social Influence, supra note 12, at 367-73 (no mention). 


\section{B. Other Factors That Are Overshadowed by the Orderliness of Order-Maintenance Policing}

It would be crucial to further investigate the potential link between the policy of aggressive arrests and police brutality. Short of a causal link, the arrests themselves are a serious ordeal. "Handcuffed, fingerprinted and often strip-searched, defendants spend as much as a day in jail before seeing a judge, who generally considers that punishment enough."357 According to the New York Times, as recently as November 1996, "some people were held in cells for more than 60 hours waiting to see a judge for crimes like farebeating, sleeping on park benches and drinking beer in public."358 Transportation to the precinct, if by van, can take up to four or more hours. ${ }^{359}$ In addition, arrest creates a criminal record that may haunt people on future job and school applications.

The New York Times recently published a short self-help manual for dealing with arrest. The article chronicled the likely course of events and offered some tips. "While being handcuffed, cross one hand over the other. It's more comfortable." "Carry valid ID. It increases your chances of being released with an appearance ticket, instead of being held overnight." "If you are worried about being assaulted while in custody, sit near the front of the cell where guards can see you." 360 The ordeal of arrest can be a harrowing experience. A sample of cases reported in the papers illustrate this well. Chris $\mathrm{C}$. was at the wrong place at the wrong time. Looking for a friend's name on the mailbox in the lobby of an apartment building in the East Village, Chris fell into the hands of officers hunting drug activity. Accused of trespass, Chris was arrested, handcuffed, taken to jail, strip-searched, and held for nineteen hours; his case was dismissed two months later. ${ }^{361}$ Nancy T. was pulled over and arrested in Chinatown, handcuffed, taken to the station house, strip-searched, and locked up till early next morning, for driving without her license and talking back to a police officer ("failure to comply with an order"). ${ }^{362}$ Max M., a twenty-one-yearold college student "was accused of drinking a beer on the street on

357. Purdy, supra note 11.

358. Cooper, supra note 11.

359. See id.

360. Id. Note that, in light of the NYPD's new policy regarding checking identification by means of fingerprints, the second recommendation may no longer be that useful.

361. See Purdy, supra note 11.

362. See Sontag \& Barry, supra note 11. 
the Upper West Side and spent a day in jail."363 To be sure, these are just stories reported in the New York Times, but they help us to see what we so badly want to ignore. Misdemeanor arrests affect real people, not just statistics.

Misdemeanor arrests also have a disparate impact on minorities. The demographic breakdown of misdemeanor arrests reflects that a disproportionate number of minorities are arrested for misdemeanors - disproportionate in relation to the percentage of minorities in the population, though not necessarily in relation to the racial breakdown of persons committing misdemeanor offenses. The point is not that the police are disproportionately targeting black versus white misdemeanants. The point is that more blacks are arrested for misdemeanors than whites given their proportion in the overall population. The decision to arrest misdemeanants - rather than not arrest them - is a policy that has a disparate impact on minorities.

In cities throughout the United States, a high percentage of persons arrested for misdemeanors are black. This is reflected in the following table, which compiles the racial break-down for arrests in cities in 1995:364

TABle 15: Demographic Break-Down of Misdemeanor ARRESTS FOR CITIES IN 1995

$\underline{\text { Percent White }} \quad \underline{\text { Percent Black }}$

Population $(132,911,000)$

Misdemeanor Arrests:

Disorderly conduct

Drug abuse

Drunkenness

$61.2 \%$

$58.7 \%$

$79.4 \%$

Prostitution

Suspicion

Vagrancy

$59.9 \%$

$40.9 \%$

$50.9 \%$

Vandalism

$71.0 \%$

$36.9 \%$

$40.3 \%$

$17.7 \%$

$37.7 \%$

$58.7 \%$

$46.4 \%$

$26.3 \%$

The table reveals how misdemeanor arrests disproportionately impact blacks. It is particularly striking in the case of arrests for suspicion - where 58.7 percent of persons arrested are black. It is also striking in most other categories, give that the 1990 Census reported that African-Americans make up only $13 \%$ of the popula-

363. Purdy, supra note 11.

364. See SourCebook of CRIMINAL Justice STAtistics-1996, supra note 39, at 386 tbl.4.12 (listing racial breakdown of arrests in all cities, including cities with less than 10,000 inhabitants, see id., app. 3 at 595). I used the more conservative numbers of total arrests rather than the numbers for arrests 18 and older. It appears that adult misdemeanor arrests are even more skewed against blacks. 
tion inside metropolitan areas. ${ }^{365}$ A policing strategy that targets misdemeanors is likely to have a disproportionate effect on minorities. Such a strategy may also have a disproportionate impact on the homeless who, almost by definition, violate misdemeanor laws against loitering and public drinking., ${ }^{366}$

Moreover, the policy may facilitate an uncomfortable delegation of the power to define community standards. Recall, for a moment, police officer Kelly in Newark. One of his rules of ordermaintenance was that "[i]f a dispute erupted between a businessman and a customer, the businessman was assumed to be right, especially if the customer was a stranger." 367 There is reason to suspect, however, that this unwritten rule might not reflect the voice of all members of the community. It may in fact reflect none. The businessman may himself live in a completely different neighborhood.

Clyde Haberman of the New York Times recently asked, slightly facetiously, "a humble question" on the quality-of-life initiative: "Whose life is it, anyway, that we're talking about?"368 Referring to the campaign against squeegee men, Haberman remarked to himself,

Wait a minute, dummy, you don't own a car. No squeegee man ever ruined your day. And you know what? The same is true for most New Yorkers, since the city's Transportation Department says that 56 percent of them do not have access to a car, let alone even occasional contact with curbside window washers. ${ }^{369}$

Haberman's amusing comments must be taken in perspective; the quality-of-life initiative has also targeted the subway system and other pedestrian venues. But the humble question is still an important one. How do we define minor disorder? Clearly, we are not talking about arresting those who pay their house keeper in cash to knowingly benefit from IRS underreporting, or who pay their nannies under the table. The quality-of-life initiative focuses instead on the type of minor offenses - loitering, fare-beating, and panhan-

365. See 1990 Census of Population, at 7 tbl. 5 (listing racial breakdown inside metropolitan areas, defined as including urbanized areas with a minimum population of 50,000 , see id. at A-8).

366. I thank my colleague Andrew Silverman, who has worked extensively on issues of homelessness, for alerting me to this problem. See also Barnes, supra note 5, at 24-25 (reporting on a study in Austin, Texas, that found that "[a] third of the arrests for public order offenses were of repeat offenders, of whom two-thirds were homeless").

367. Wilson \& Kelling, supra note 2, at 30.

368. Clyde Haberman, Better Quality of Life Found Behind Wheel, N.Y. TIMEs, Jan. 16, 1998 , at B1.

369. Id. 
dling - that affect the poorer members of society, which, tragically, include a disproportionate number of minorities. Who gets to define disorder? By handing over the informal power to define deviance to police officers and some community members, we may be enabling the repression of political, cultural, or sexual outsiders in a way that is antithetical to our conceptions of democratic theory or constitutional principles. 370

Arrests and prosecutions are also very expensive. A typical prostitution prosecution - one of the offenses targeted by the quality-of-life initiative - costs upwards of $\$ 2,000.371$ That is a lot of money for a law-enforcement strategy unsupported by empirical evidence. Finally, a policy of arrest may have unintended consequences. Someone arrested for turnstile jumping may be fired from his job for missing work; and strained police-civilian relations can create friction between the community and the police force that may be detrimental to solving crimes. ${ }^{372}$

\section{Alternatives to Arrest}

Alternatives to a policy of aggressive misdemeanor arrests may exist. Instead of arresting turnstile jumpers, for instance, we can and New York City has begun to - install turnstiles that cannot be jumped. This is an approach similar to "target-hardening" or "access control," methods of situational crime prevention that are commonly discussed in criminology. ${ }^{373}$ Instead of arresting prostitutes, we could investigate the possibility of licensing prostitution. It turns out, in fact, that prostitution may be related to crime in a more direct way than the broken windows theory immediately suggests. Deborah Rhode has recently compiled some relevant statistics. "Recent research estimates that two-thirds to three-fourths of streetwalkers are raped or beaten an average of four to 15 times a

370. This is not to suggest - one way or the other - that African-American communities like or dislike order-maintenance policing. Broken windows proponents rightly mock liberals who suggest that the black community should be opposed to order-maintenance policing, see Kahan, New Path, supra note 12, at 2482; Wilson \& Kelling, supra note 2, at 35-36, although these proponents often fall prey to exactly the same fallacy. See, e.g., Kahan, New Path, supra note 12, at 2482 (referring to inner city residents as "the very citizens" who support "public-housing building searches, curfews, and gang-loitering laws"). To suggest anything about the position of the black community would be both reductionist and essentialist.

- 371. See Rhode, supra note 40.

372. As my colleague Henry Ruth suggests, "it is witnesses that solve crimes, not police officers."

373. See, e.g., Ronald V. Clarke, Situational Crime Prevention, in BuILding A SAFER So. CIETY 91 (Michael Tonry \& David P. Farrington eds., 1995). 
year."374 Studies suggest that decriminalizing prostitution (in the case of the Netherlands) and/or legalizing prostitution (in the case of eleven counties in Nevada) has resulted in lower crime rates against prostitutes, as well as lower rates of sexually transmitted diseases. $^{375}$ A full exploration of these alternatives is beyond the scope of this Article and, to be sure, decriminalizing or licensing prostitution may not eliminate an underground black-market in prostitution. It is, however, an alternative worth investigating. After all, aggressive arrests have not eliminated prostitution in New York City. The New York Times reports that "while prostitution may be less visible in the city, it is no less prevalent. The Internet, pagers, cellular phones and subterfuges like escort services have enabled more discreet forms of prostitution to thrive beyond the reach of the street-level crackdown, the authorities and prostitutes themselves say."376

How can we discourage aggressive panhandling and other forms of street economies? Instead of arrest, perhaps we should explore the possibility of work programs for people living on the street. The programs could target cleaning up abandoned buildings, creating public parks out of vacant lots, creating space for public art projects, or maintaining public spaces. If the programs were flexibly designed to facilitate changing work schedules, they might offer a substitute to panhandling and window-washing. As for the financing, we could investigate the possibility of taxing owners of abandoned property or using proceeds from the sale of abandoned properties, as well as a tax on emissions, or fines for littering. There are endless ways of resolving the problem of panhandling if we let our imaginations roam within a realistic and practical realm.

The mayor of Bogota, Columbia, Antanas Mockus, hired mimes to follow and imitate jaywalkers crossing the street in an effort to

374. Rhode, supra note 40; see also Charles Clark, Prostitution, CQ Researcher, June 11, 1993, at 514; Jessica N. Drexler, Governments' Role in Turning Tricks: The World's Oldest Profession in the Netherlands and the United States, 15 DICK. J. INTL. L. 201, 207-08 (1996); Eleanor M. Miller et al., The United States, in Prostrrution: An InTernational Handbook on Trends, Problems, and Policies 300, 320 (Nanette J. Davis ed., 1993).

375. See Drexler, supra note 374, at 228, 230; see also Linda M. Rio, Psychological and Sociological Research and the Decriminalization or Legalization of Prostitution, 20 ARCHIVES of Sexual Behav. 205, 212-14 (1991); Claire Sterk-Elifson \& Carole A. Campbell, The Netherlands, in Prostitution: An International Handbook on Trends, Problems, AND Policies, supra note 374, at 191, 200-02; James R. Stout \& Thomas S. Tanana, Note, Could California Reduce AIDS by Modeling Nevada Prostitution Law?, 2 SAN Diego Just. J. 491, 498 (1994).

376. Kit R. Roane, Prostitutes on Wane In New York Streets But Take to Internet, N.Y. TIMEs, Feb. 23, 1998, at A1. It may be fair to say that, in this case, order on the streets has been achieved by means of disorder in cyberspace. 
curb jaywalking. ${ }^{377}$ Mockus also gave motorists "cards with a thumb-downs sign that they could hold up, like soccer referees, to signal that another driver had committed a foul." 378 It's a different approach, but the point is, even if we set out to create order, we should consider how we are going to go about it. We need to critically examine what effect the policies will have on individuals in society, how the policies construct the subject and how that construction reinforces the very strategies we are justifying. ${ }^{379}$ The issue is not just social influence on behavior. The pertinent questions are, first, how do our strategies of policing and the mechanisms of punishment transform the subject? Second, how does our understanding of the subject influence the policing strategy under consideration? And third, how do these effects relate to the goal of reducing crime? The answer, in the context of order-maintenance policing is that the quality-of-life initiative creates the disorderly, which in turn reinforces the policing strategy and overshadows the costs of that strategy, without sufficient evidence that the orderdisorder axis affects crime.

\section{CONCLUSION}

Let's return for a moment to January 22,1840 , the official opening of Mettray, a juvenile prison qua home, school, military compound, and factory described in chilling detail by Michel Foucault in Discipline and Punish. ${ }^{380}$ Consider for a moment the policy at Mettray, as reported by Ducpétiaux in 1852: "The least act of disobedience is punished and the best way of avoiding serious offences

377. See John Tierney, Civil Obedience, N.Y. Times, Apr. 19, 1998, § 6 (Magazine), at 26.

378. Id.

379. The example of prostitution, again, provides a useful illustration. Licensing prostitution might have a very different effect on the subject than aggressively arresting mostly female prostitutes. It would likely have less of a marginalizing effect on the women and men that engage in prostitution. Persons engaged in sex work would likely receive more protection from our sexual assault laws. Prosecutors' charging decisions may be affected. Sex workers might acquire a voice in the debate about whether and how to change the social meaning and social practice of prostitution. Sex workers likely would have a greater amount of control over their identities. And there may be corresponding effects on persons who are not engaged in acts of prostitution, on sexual relationships, and on the construction of sexuality in society more generally. This is just the very beginning of the type of inquiry that subject creation theory calls for. The point here is not to resolve that inquiry in the case of prostitution or any other specific misdemeanor offense, but rather to illustrate the type of questions that we should be asking. Excellent work is being done in this particular area by Lisa Sanchez. See Lisa E. Sanchez, Boundaries of Legitimacy: Sex, Violence, Citizenship, and Community in a Local Sexual Economy, 22 L. \& Soc. InourRy 543 (1997); see also Kennedy, supra note 300 , at 126.

380. Foucault, Discipline and Punish, supra note 34, at 293-96. 
is to punish the most minor offences very severely." 381 It is eerie how much this resembles the social influence conception of deterrence. Perhaps the new path of deterrence is not so new after all.

Order-maintenance policing is extremely popular these days. With crime rates plummeting in New York City, few if any are foolish enough to take issue with the quality-of-life initiative. Most people praise it, especially elected officials and policy-makers who, by doing so, can take full credit for the decline in crime. ${ }^{382}$ But the new policing in New York City overestimates the role of disorder in the production of crime. By overestimating disorder, it creates a false choice between the police and the disorderly - a choice that may facilitate a policy of aggressive arrests despite the lack of empirical evidence supporting the claim of deterrence. The ironic consequence is that the social influence conception of deterrence touted as an alternative to "the severe punishments that dominate contemporary criminal law"383 and presented as an application of social norm theory - falls back on a law enforcement strategy that relies principally on arrest and incarceration.

What then is hidden beneath the new path of deterrence? I think we see it best in the Broken Windows essay. The text suggests that reducing crime is simply a question of minor details, of fixing broken windows, of sweeping up litter, of hiding the street people. It neglects the numerous and complex factors that contribute to crime. Recall the description in the Broken Windows essay about neighborhood decline:

A piece of property is abandoned, weeds grow up, a window is smashed. Adults stop scolding rowdy children; the children, emboldened, become more rowdy. Families move out, unattached adults move in. Teenagers gather in front of the corner store. The merchant asks them to move; they refuse. Fights occur. Litter accumulates. ${ }^{384}$

This description may tell us a few things about litter and public drinking. But there is also lurking in that description a much more complex story about urban decay, with complicated race, wealth, class, and ethnic dimensions, to name only a few. The more complex story would raise questions about property values, the quality of neighborhood public schools, racial demographics, environmental pollution, public transportation, access to business loans and

381. Foucault, Discipline and Punish, supra note 34, at 294 (quoting Ducpétiaux $1852,377)$.

382. See Bratton, supra note 8.

383. Kahan, New Path, supra note 12, at 2478.

384. Wilson \& Kelling, supra note 2, at 32. 
mortgages, and zoning laws. The life cycle of a neighborhood is not as simple as the essay suggests. ${ }^{385}$

Many readers may simply respond: "But what about all the New Yorkers who feel safer in the new, orderly New York? Aren't their feelings entitled to some weight in the analysis?" The simple answer is that New Yorkers are feeling safer because they are safer. Crime rates have tumbled in New York City. There is every reason to feel safer. The longer response is that their feelings are central to the analysis presented here - an analysis that focuses, after all, on the way that subjects are created by means of the norm of orderliness.

Some readers may nevertheless persist and call attention to the social scientific studies that suggest that people feel safer in more orderly neighborhoods. 386 "New Yorkers are feeling safer not only because of the lower crime rates," they may argue, "but also because of the additional order." There are, again, two answers. The simple answer is that these feelings of safety are most likely explained by the level of crime in the neighborhood. ${ }^{387}$ The longer answer is that this come-back is really about aesthetic preferences - a discussion that is beyond the scope of this Article.

This offers a good opportunity to emphasize what I have not argued in this Article. First, I have only addressed the social influence justification for order-maintenance policing. I have only addressed the claim that deterrence justifies the quality-of-life initiative. There may be other justifications. Some may argue that we should arrest minor misdemeanants because their conduct is morally reprehensible. Others may suggest that the conduct is aesthetically unpleasant. I have not directly addressed those claims of moral theory or aesthetic preferences. This Article is limited in scope to the justification based on deterrence. It may have implications for moral theory or aesthetics, but those implications should not be mistaken for a full-blown discussion. Second, this Article does not challenge community policing. Community policing comes in far too many varieties to draw any conclusions here about community policing writ large. Order-maintenance policing New York style is just one of many different approaches to community policing. It focuses on arrests. There are, however, other types of

385. Wesley Skogan acknowledges and discusses this point in his study, see Skogan, Final Report, supra note 22 , at 77, and, I believe, would agree with this criticism of the Broken Windows essay.

386. See, e.g., SKOGAN \& MAXFIELD, supra note 100.

387. See SKOGAN, Disorder AND DECLINE, supra note 9, at 77. 
community policing, some of which even emphasize police cooperation with disorderly people. 388 Finally, this Article does not address the strategy of increasing the number of police officers on the street. There is reason to believe that integrating more police officers into the community will help fight crime. I have limited myself to the policy of aggressive misdemeanor arrests to deter serious crime.

In conclusion, the categories of the disorderly and law abiders, of order and disorder, limit our horizon. When we attempt to think about reducing violent crime - about, in effect, transforming society - we need to question these categories and, if we find them limiting, offer alternative understandings that lead to more innovative policies. My goal in this Article has been to dig beneath the new path of deterrence in order to expose some alternatives. If we want more order on the streets, there may be alternatives to misdemeanor arrests. Overall, we should refocus our attention on the numerous forces that contribute to declining neighborhoods, poverty, and crime, and that are masked by the aesthetic and rhetoric of orderliness. The statistical analysis presented here suggests that disorder may mask the role of neighborhood poverty, stability, and race in relation to crime. The same may be true of the social influence conception of deterrence.

388. Under some approaches, police officers use their power to withhold enforcement of misdemeanors as' a way to integrate into the community. See, e.g., Eig, supra note 43 (discussing community policing in Chicago). Eig reports that his officer-informant "rarely writes tickets." Id. at 63 . Eig explains:

For one thing, she rarely writes tickets. While we are out on patrol one night, a car rolls through a four-way stop sign without even pausing. The driver sees the police car, puts an upturned palm out his window and shouts, "Sorry, T-Bone!" Black [the officer] just shakes her head. Another time, she spots a man who is wanted for a parole violation. He does not run when Black approaches. ... [H] and Black agree that she will pick him up the next day.... Black is confident he'll keep his word. She understands that respect and goodwill benefit her more than force. Once, when a suspect resisted arrest and began punching her, neighborhood gang members rushed to her defense and helped subdue the man. 